\title{
NETWORK BROKERAGE:
}

\section{AN INTEGRATIVE REVIEW AND FUTURE RESEARCH AGENDA}

\author{
Seok-Woo Kwon \\ Haskayne School of Business \\ University of Calgary \\ Scurfield Hall 470 \\ 2500 University Dr. NW, Calgary, AB T2N 1N4, Canada \\ 1.403.220.6646 \\ seokwoo.kwon@ucalgary.ca \\ Emanuela Rondi \\ Free University of Bozen-Bolzano \\ Bolzano, 39100, Italy \\ emanuela.rondi@unibz.it \\ Daniel Z. Levin \\ Management and Global Business Dept. \\ Rutgers Business School - Newark and New Brunswick \\ Rutgers University \\ 1 Washington Park \\ Newark, NJ 07102 \\ levin@business.rutgers.edu \\ Alfredo De Massis \\ Free University of Bozen-Bolzano \\ Bolzano, 39100, Italy \\ alfredo.demassis@unibz.it \\ and \\ Lancaster University Management School \\ Lancaster, LA1 4YX, United Kingdom \\ a.demassis@lancaster.ac.uk
}

\section{Dan Brass}

J. Hennings Hilliard Chair in Innovation Management

Director, LINKS Center for Social Network Analysis

Chair, Department of Management

Gatton College of Business \& Economics

University of Kentucky

Lexington, Kentucky 40506

dbrass@uky.edu

Accepted for publication, Journal of Management

March 3, 2020 


\title{
NETWORK BROKERAGE:
}

\section{AN INTEGRATIVE REVIEW AND FUTURE RESEARCH AGENDA}

\begin{abstract}
Network brokerage research has grown rapidly in recent decades, spanning the boundaries of multiple social science disciplines as well as diverse research areas within management. Accordingly, we take stock of the literature on network brokerage and provide guidance on ways to move this burgeoning research area forward. We provide a comprehensive review of this literature, including crucial dimensions of the concept itself, in terms of brokerage structure and behavior, a set of key categories of factors surrounding the brokerage concept (antecedents, outcomes, and moderators), and an overview of brokerage dynamics over time. We use these dimensions and categories to depict network brokerage's theoretical and empirical underpinnings, as well as evaluate prior research efforts. In so doing, we offer a means to summarize and synthesize this large, interdisciplinary literature, identify important research gaps, and offer promising directions for future research.
\end{abstract}




\section{INTRODUCTION}

A key challenge in management is trying to understand, construct, and make use of the set of relationships among individuals, groups, and/or organizations—social networks. In studying these networks, one of the most important concepts to emerge has been brokerage. Network brokerage ("brokerage" for short) describes an activity of a network actor (broker) occupying a structural position (bridge, structural hole) between two or more otherwise disconnected actors (hereafter referred to as alters), and it typically involves an exchange or interaction between the broker and the alters. Brokers are often conceptualized as entrepreneurs leveraging their position in a network structure to achieve their private (Burt, 2005) or the collective's (Clement, Shipilov \& Galunic, 2018) goals.

The core intuition behind the brokerage concept has been credited to Simmel's classic discussion of third-party influence (1950) and Granovetter's (1973) seminal article on weak ties and "forbidden triads," although neither Simmel nor Granovetter used the term "brokerage". Eventually, social scientists converged on the use of the term brokerage to describe these ideas (Burt, 1992). The brokerage idea builds on network arguments such as betweenness centrality (Freeman, 1977), benefits of having exclusive exchange partners (Cook \& Emerson, 1978), and competitive advantage and structural autonomy created by structural holes in networks (Burt, 1980). Since the idea of brokerage can be a lens to study numerous social phenomena, brokerage research has spanned across multiple social science disciplines as well as diverse research areas within management.

The past decade has seen a dramatic increase in the number of studies investigating brokerage, resulting in a rather splintered, fragmented understanding of the concept. Often departing from its seminal conceptualization, research on brokerage has expanded in multiple 
directions, leading to mixed or confusing findings and showing that its benefits are contingent on many factors. The need for conceptual clarification is especially urgent, as the field has become inundated with brokerage research without a clear understanding of how the splintered studies relate to or build on each other.

In an effort to address this challenge and make sense of this burgeoning literature, we reviewed 170 studies. While there were a number of previous reviews of social networks that, in part, address brokerage (Burt, 2005; Carpenter, Li \& Jiang, 2012; Tasselli, Kilduff \& Menges, 2015) or specific networks (Phelps, Heidl \& Wadhwa, 2012), a focused review on brokerage has been rather sparse (however, see Stovel and Shaw (2012) for a review of the sociology literature on brokerage and Halevy, Halali, and Zlatev (2019) for a review of third-party influence as applied to brokerage). Our goal is (1) to develop a comprehensive theoretical framework that organizes the brokerage literature, (2) to use our framework to review extant research within and across multiple research areas, and (3) building on this review, to highlight the theoretical and empirical gaps that continue to plague the brokerage literature and suggest several future research directions for advancing the state of brokerage research. In doing so, our primary focus is on conceptual synthesis, not on individual studies or on purely methodological or technical contributions.

\section{SCOPE AND METHOD OF THE REVIEW ${ }^{1}$}

To manage the scope of our review and ensure coverage of relevant studies in our sample, we searched the ISI Web of Knowledge database for academic publications containing in articles' title, abstract, or keywords the term "broker" or other related terms (such as "structural hole", "boundary spanning”, "betweenness", "bridging”, "tertius iungens", "tertius gaudens", "triad”, or

\footnotetext{
${ }^{1}$ Online supplement Figure S1 and a Methodological Supplement provide a detailed description of the articleselection process. We also provide details of each study in online supplement Table S1.
} 
"referral") combined with "network". We then refined the search to 58 top- and middle-tier journals in management or related fields, as well as the top specialty journal in this domain, Social Networks. Each of the remaining articles was then analyzed according to six exclusion criteria, eliminating articles that (1) did not specifically and explicitly focus on brokerage, (2) considered networks as a collection of dyads, thereby neglecting the role of third-party, (3) considered brokerage as an occupation rather than network intermediary, (4) focused exclusively on methodological and measurement issues, (5) focused on non-human social networks or relied on computer simulations, or (6) dealt with networks outside a work or professional context. Ultimately, this process led to a final population of 170 articles published in recent decades.

\section{A FRAMEWORK FOR UNDERSTANDING NETWORK BROKERAGE}

To ease the review of the diverse body of work on brokerage, we developed a framework (see Figure 1). This comprehensive framework categorizes recent brokerage research into five broad areas: (1) antecedents, the factors that lead actors to undertake brokerage, (2) the dimensions of brokerage concepts (structure and behavior), (3) brokerage outcomes, (4) moderators, factors that moderate brokerage performance, and (5) brokerage dynamics over time. Below, we present our full review of this literature, using this framework. Because our review identifies two primary conceptualizations of brokerage — structure and behavior-our review begins with brokerage structure, followed by brokerage behavior ("brokering"), and then considers antecedents, outcomes, and moderators of brokerage, as well as brokerage dynamics over time.

Insert Figure 1 about here

\section{Brokerage as Structure}

Structural conceptualizations of brokerage have dominated the literature (Stovel \& Shaw, 
2012). Brokerage occurs when one actor (the broker) is connected to two other actors (alters) who are not themselves connected. This brokerage structure is variously called a structural hole, an open triad, an open structure, a lack of closure, a lack of network constraint, a brokerage tie, or a bridge. ${ }^{2}$ Although Granovetter's seminal paper (1973) focused on tie strength, his theoretical rationale was structural: He argued that network bridges are a direct consequence of weak ties, because strong ties between a focal actor ("ego") and alters are likely to produce closure (where all the parties are connected) through the process of transitivity, or a desire for balance. Open triads (where actor A has a tie to B and to C, but there is no tie between B and C) with strong ties are rare and famously labeled "forbidden" by Granovetter (1973). Burt further refined this idea by arguing that "Tie weakness is a correlate, not a cause" (Burt, 1992: 27), and thus shifting the causal emphasis from the weakness of a tie to the structural hole it spans.

Most of the research we reviewed focuses on a broker's direct ties to alters ("direct brokerage"), ignoring the broader network beyond these alters. However, an emerging stream looks at the extent to which a focal broker's alters are also bridging structural holes ("secondhand brokerage"), i.e., on whether the alters themselves have open or closed networks. The potential advantage of secondhand brokerage is that alters who broker other relationships acquire additional diverse information that can potentially be passed along to the focal broker (McDermott, Corredoira \& Kruse, 2009). Thus, the theoretical mechanisms explaining potential benefits from secondhand brokerage mirror those for direct brokerage (see Outcomes section below), namely, the spillover benefits come from the alter's brokerage benefits of non-redundant resources and control, contingent on the alter's willingness to share with ego, the focal broker. Just as cooperation

\footnotetext{
${ }^{2}$ We note that some network studies refer to "bridges" (or boundary spanning) not in the classic network-brokerage sense of a broker being linked to otherwise disconnected alters but rather as ties that bridge across a formal organizational boundary (Tortoriello \& Krackhardt, 2010) across areas of expertise (Reagans \& McEvily, 2003), or across demographic groups (Reagans \& Zuckerman, 2001).
} 
and trust can enhance the benefits of direct brokerage (Levin, Walter, Appleyard \& Cross, 2016), they may also enhance secondhand brokerage: in a cooperative situation, both brokers may benefit; in a competitive context, both brokers may suffer as each tries to take advantage of the other.

Empirical support for secondhand brokerage has largely tracked this idea that (1) secondhand structure in general does not necessarily confer any benefits, but (2) special configurations of secondhand brokerage that provide both novelty and cooperation do provide benefits. To the first point, in two studies and across several samples, Burt $(2007,2015)$ found no additional secondhand benefits for the focal broker beyond those explained by direct brokerage. However, to the second point, other studies have found performance benefits of secondhand brokerage if the focal actor's alters are brokers who can provide a needed benefit of novelty and cooperation (Clement et al., 2018; Galunic, Ertug \& Gargiulo, 2012). These cases suggest that the benefits of secondhand brokerage are contingent, i.e., it is helpful only under circumstances when it combines information diversity with trust and cooperation. Interestingly, another study actually found performance benefits for secondhand closure-where one's alters have networks that are closed, not open like with secondhand brokerage—yet these seemingly opposite findings actually followed a similar logic: the benefits for ego were contingent on structural configurations where the alters had both a novelty benefit to offer as well as an incentive to cooperate (Shah, Levin \& Cross, 2018).

A second, related emerging stream formally extends the structural analysis to include the group membership of the broker and alters within the overall configuration of the extended network. For example, Fernandez and Gould (1994) identified five different broker types, with expected brokerage activity, depending on the configurations of group members among the actors in a network: A broker can be a coordinator, enhancing interaction between the members of the 
group the broker belongs to; a gatekeeper, absorbing knowledge from another group and passing it to the other members of the broker's group; a representative when the broker diffuses the knowledge of the broker's own group to another group; an itinerant broker if the broker mediates between members of a group the broker does not belong to; or a liaison if the broker mediates between members of different groups (c.f., Boari \& Riboldazzi, 2014).

While the Fernandez and Gould (1994) typology considers brokers as a member of a single group only, Krackhardt (1999) points out that brokers may have multiple group memberships. He proposes that "Simmelian brokerage" can occur when the broker is a member of two densely connected cliques (everyone, including the broker, is reciprocally tied to everyone else in the clique) and, at the same time, the only link between the cliques. Being a member of a densely connected, closed group can be constraining, and being the only link between two such groups can produce "ties that torture" as the broker faces dual constraints. Unlike the broker in the Fernandez and Gould (1994) typology who enjoys autonomy and discretion, Simmelian brokers feel highly monitored and constrained.

\section{Brokerage as Behavior}

While the opportunities afforded by the structure of network ties are necessary for brokerage to occur, these structural opportunities by themselves do not necessarily trigger brokering behavior (Smith, 2005), as "networks do not act but are context for action" (Burt, 2004: 354). Acting on these brokerage opportunities requires "the intellectual and emotional skills developed in the process of encoding and decoding information to communicate between diverse contacts" (Burt, Kilduff \& Tasselli, 2013: 536). Thus, research is increasingly devoting attention toward brokerage behavior (Boari \& Riboldazzi, 2014; Quintane \& Carnabuci, 2016), or brokering, i.e., the actions and network processes related to brokerage. This conceptualization of brokerage 
examines what brokers actually do (Batjargal, 2010), including the strategic actions of "network architects" (Pollock, Porac \& Wade, 2004: 50). Although our review revealed far fewer studies of brokerage behavior, we see this area as a welcome development that has the potential to uncover and confirm the theoretical mechanisms often assumed to accrue automatically to occupants of brokerage positions in a network.

Our review identified two broad categories of brokerage behavior, focusing on how a broker either maintains the separation between alters in open triads, or transforms open into closed triads: we refer to the former category as tertius separans (the third who separates), and the latter, as tertius iungens (the third who joins). Note that tertius separans behavior is usually referred to as tertius gaudens (the third who benefits), but we agree with Burt (forthcoming) that tertius separans is a more appropriate label as brokers can benefit from both joining and separating alters. When brokers behave as tertius separans - also called disjunct (Grosser, Obstfeld, Labianca \& Borgatti, 2019) or arbitraging (Soda, Tortoriello \& Iorio, 2018), as well as tertius gaudens (Obstfeld, 2005) - they keep the alters unconnected. According to Spiro and colleagues (2013), brokers can engage in this tertius separans behavior through two types of brokerage processes: transfer and coordination. In transfer brokerage, the broker controls the "flow" from one side of the network to the other, without attempting to link the alters directly (Obstfeld, Borgatti \& Davis, 2014). For example, a broker can learn how to use a technology from one alter and deliver that knowledge to another alter that does not have it (Hargadon, 2002). In coordination brokerage, a broker mediates between the alters so that the need of any alter-alter contact does not arise. For example, Fernandez and Gould (1994) point to the role of the Federal Reserve Bank in a major city: transactions among many smaller banks are frequently conducted through the central bank rather than directly, since it serves as a kind of clearinghouse for all the banks in its area. 
In contrast, when brokers behave as tertius iungens (the third who joins) —also called catalyst (Stovel, Golub \& Milgrom, 2011) or collaborating (Soda et al., 2018) brokerage - they try to introduce or facilitate ties between previously unconnected alters (Obstfeld, 2005), engaging in matchmaking (Ebbers, 2014). When a broker introduces or facilitates such ties between alters, this iungens behavior can either decrease in importance over time (brief iungens) or stay essential (sustained iungens) (Obstfeld, 2005).

Although the literature has generally suggested that tertius separans and iungens are actorspecific and thus intrinsic to each broker, some argue that these two brokerage behaviors can be used by the same broker depending on the task (e.g., Lingo \& O’Mahony, 2010). For example, Baker and Obstfeld (1999) argue that tertius separans (keeping alters apart) behavior works better in a competitive market with sparse networks, whereas tertius iungens (bringing alters together) behavior is more effective in a cooperative context with dense networks. Whereas tertius separans allows access to novel information, tertius iungens is helpful for integrating diverse ideas and implementing new ideas (Lingo \& O’Mahony, 2010).

Whereas the brokering behaviors reviewed above occur in an open triad, we see different sets of behaviors manifested in a closed triad. When all actors are connected in closed triads, the positional advantages of a broker largely disappear, and one could argue that any behavior directed toward others in the closed triad might be considered brokerage, making the concept incomparable to brokerage behaviors in an open triad, and more akin to third-party influence than brokerage (Burt, forthcoming). Of course, this does not mean that all ties within closed triads are equally activated, as actors rarely if ever transact everything with everyone. So a tertius iungens approach, for example, might still provide value even if all three parties know each other (e.g., "I mentioned to our coworker Jane that you're doing a sales call next week at Company X, and it turns out she 
used to work there and still knows a lot of people; you should talk with her.”). Thus, even in a closed triad, there may be opportunities for brokerage behavior and third-party influence, i.e., situations where one actor has the time, ability, or motivation to learn more about the other two than they know (or care to know) about each other.

Halevy, Halali \& Zlatev (2019) provide a review of brokerage-type behavior in closed triads, focusing on actor interdependence and third-party influence. Applying interdependence theory (e.g., Kelley \& Thibaut, 1978), they develop a "Changing Others' Relationships” (COR) framework based on the premise that "brokering activities target others' relationships" (p. 219). They further offer a longitudinal perspective on pre- and post-intervention influence that results in either helpful or harmful brokers. Their study provides insights on third parties creating, reinforcing, changing, and terminating relationships, suggesting other forms of brokerage behavior (e.g., social introductions, gossip, conflict management) in addition to the previously researched tertius behaviors.

Finally, an emerging stream of brokerage behaviors focuses on cultural brokerage. Emphasizing the role of context, Pachucki and Breiger (2010) argue that a broker crosses boundaries not just between social circles (i.e., across structural holes in a network), but also across different cultural communities ("cultural holes"). Actors bridging across a structural hole have access to diverse information, but the information they access may be hard to interpret and absorb (Aral \& Van Alstyne, 2011). A cultural broker with the ability to interpret information and translate to others can bridge these cognitive gaps (Carlile, 2004) or "thought worlds" (Dougherty, 1992). For example, van Wijk et al. (2013) found that, whereas network brokers establish connections across different parts of a network, cultural brokers connect ideas across discourses so that they will be more readily accepted by others. Cultural brokers either transform and combine diverse 
cultural knowledge into new solutions (Hargadon \& Sutton, 1997) or translate and make more complex knowledge meaningful (Boari \& Riboldazzi, 2014).

\section{Antecedents of Brokerage}

Our review of brokerage antecedents revealed a focus on actor agency and on environmental/contextual factors beyond the control of actors. From the agency approach, Burt (2012) noted that individuals who occupy a network broker position in one role will tend to occupy a similar position in other roles. What explains this consistency for individuals? One answer is the personality variable of self-monitoring, the "active construction of public selves to achieve social ends" (Gangestad \& Snyder, 2000: 546). High self-monitors—who aim to make a good impression and fit in, chameleon-like, in different situations rather than stay consistent across situations - tend to occupy broker positions in the network structure (Sasovova, Mehra, Borgatti \& Schippers, 2010). The effect of self-monitoring on brokerage is amplified in individuals perceived as highly empathic (Kleinbaum, Jordan \& Audia, 2015) and with longer tenure in the organization (Mehra, Kilduff \& Brass, 2001). Other personality variables have been explored (e.g., Kalish \& Robins, 2006), but a meta-analysis found that personality had a fairly small impact on being a broker (Fang, Landis, Zhang, Anderson, Shaw \& Kilduff, 2015).

Variation in actors' awareness of network ties is another antecedent of brokerage. People seem to be poor at seeing structural holes, as most people tend to see ties in their network where holes exist (Freeman, 1992). To the extent that people can be trained to recognize structural holes (Janicik \& Larrick, 2005) and taught to network more strategically (Burt \& Ronchi, 2007), this cognitive ability might be a strong predictor of brokerage behaviors.

Other studies have suggested that status differences can influence whether actors can create and occupy structural holes. High-status brokers attract disconnected alters because the 
brokers are prominent in the overall network and have selection power over whom to associate with (Sauder, Lynn \& Podolny, 2012). Moreover, feeling powerful increases one’s willingness to broker though it reduces brokerage opportunity recognition at the same time (Landis, Kilduff, Menges \& Kilduff, 2018). However, at the organizational level, Chandler, Haunschild, Rhee, and Beckman (2013) found a negative link between status and brokerage for firms.

Aside from actor agency, the organizational context also matters for brokerage creation. Thus, actors are more likely to become brokers when exposed to heterogeneous events or organizational affiliations (Stam, 2010), or at firms that encourage employees to move between teams and projects (Hargadon \& Sutton, 1997). The organizational contexts like these provide opportunities for those employees to bridge otherwise disconnected groups (Kleinbaum, 2012).

More broadly, as the external environment surrounding individuals and organizations becomes more complex, individuals and organizations have to rely more on brokers to access external knowledge to overcome internal technical and cognitive limitations (Kirkels \& Duysters, 2010). In an environment where information is poorly distributed (as when markets or hierarchies are incompletely developed, in emerging fields, or in countries with weak and inefficient formal institutions), opportunities for brokerage emerge (Batjargal, Hitt, Tsui, Arregle, Webb \& Miller, 2013). National culture can be another environmental antecedent. Burt et al. (2000) found that, compared to American managers, French managers associate negative emotions with brokerage and thus have fewer brokerage ties.

\section{Outcomes of Brokerage}

Whether the focus is structural or behavioral, the interest in brokerage and its importance rests on the outcomes. In our review of the literature, we noted two conceptual arguments underpinning the benefits of brokerage: access to non-redundant resources (primarily information) 
and control of resources. Although both are typically included as theoretical mechanisms explaining brokerage outcomes, we argue that they are analytically distinct. On the one hand, building on Granovetter's (1973) notion of the strength of weak ties, we note that actors in brokerage positions are exposed to more novelty, i.e., to a greater variety of non-overlapping knowledge flows and non-redundant information by being tied to disconnected alters. As a result, brokers may recognize entrepreneurial opportunities, creatively synthesize diverse information, and obtain a better, more timely vision of future possibilities (Burt, 2005). On the other hand, building on Simmel's (1950) notion of tertius separans (gaudens), Merton's (1957) ideas of the autonomy generated by conflicting affiliations, and traditional economic ideas of monopoly power and oligopoly, we note that brokers can also control the information (or other resources) flowing between disconnected alters. Brokers can match alters across the two sides of a market (whether it be economic, informational, or other social resources), providing value to market participants (Bidwell \& Fernandez-Mateo, 2010) and also capturing some of the value created for others (Marsden, 1982). Or, they can play alters off against each other to achieve optimal outcomes for themselves (e.g., negotiating with two venders). The tertius separans strategy of playing one alter off against another, such as in mutually exclusive exchange partners (Cook \& Emerson, 1978), requires that the resources provided by the alters are redundant. While these two mechanisms, access to non-redundant resources and control of resources, are analytically distinct, we also note that the two theoretical mechanisms are not mutually exclusive and both provide explanations for brokerage advantage and theoretical motivation for almost all the research we reviewed.

Economic returns of non-redundant resources for the broker are well documented (see Burt, 2005, for an extensive review). Our review finds that access to non-redundant information theoretically links brokerage to beneficial economic outcomes for the broker, largely overlooking 
the risks, or highlights negative economic outcomes for alters. In comparisons to non-brokers, brokers generate more resources (Aral \& Van Alstyne, 2011), profit more (Burt, 1983), receive more favorable individual performance evaluations (Burt, 2004), experience greater rates of career advancement (Brass, 1984), and receive greater compensation (Burt, 1997). Additionally, bridging ties may produce career benefits over an extended time period (McEvily, Jaffee \& Tortoriello, 2012). Similarly, organizations with extensive brokerage ties have faster revenue growth (Batjargal et al., 2013), larger market share (Baum, McEvily \& Rowley, 2012), higher profitability (Bae \& Gargiulo, 2004), more value creation and capture (Afuah, 2013), better differentiate themselves from competitors (McEvily \& Zaheer, 1999), close more deals (Mizruchi \& Stearns, 2001), and more easily obtain the necessary resources for successful performance, especially during early growth (Hite \& Hesterly, 2001). In short, brokers of non-redundant resources tend to do well economically with only a few exceptions (e.g., Shipilov \& Li, 2008).

While broker outcomes are largely positive, outcomes for alters are more mixed. Some evidence suggests that alters do benefit from brokerage (Borgatti, Mehra, Brass \& Labianca, 2009). For example, when job seekers use intermediaries to whom both the job seekers and the employers are tied, they are more likely to get hired (Granovetter, 1974) at a better job (Bian, 1997) and to be more productive (Castilla, 2005). However, other research suggests that brokers extract economic rents from the brokered alters (Fernandez-Mateo, 2007). Thus, a group's performance may suffer if it has many individuals, or a leader, occupying brokerage positions, as brokers often seek individual benefits to the detriment of group benefits (Bizzi, 2013). Perhaps as a result, when everyone in a network tries to be a broker, no one can maintain a structural advantage in the long run (Buskens \& van de Rijt, 2008).

In addition to economic outcomes, access to non-redundant information theoretically links 
brokerage to beneficial knowledge outcomes. Employees who are brokers within their organization generate more good ideas (Burt, 2004), pursue more exploratory searches in the collaboration network (Wang, Rodan, Fruin \& Xu, 2014), and demonstrate higher creativity (Li, Li, Guo, Li \& Harris, 2018), as brokers have greater and/or earlier access to non-redundant useful knowledge (Fleming, King \& Juda, 2007a), including potentially disruptive innovation (Sapsed, Grantham \& DeFillippi, 2007). Similarly, in the case of patents, inventors who span structural holes in an intraorganizational knowledge network are more likely to be cited by other inventors (Nerkar \& Paruchuri, 2005). At the organizational level, broker firms get more information (Lee, 2007), learn about novel information earlier, and produce greater innovative output (Hargadon \& Sutton, 1997) than non-brokering firms. Additionally, when dominant broker firms are committed to open dissemination of information, innovation benefits accrue not just to the specific parties directly connected to the broker firms, but also to any members in the network (Owen-Smith \& Powell, 2004). Similarly, community organizations can broker ties among isolated groups in a community so that the community becomes less polarized and more entrepreneurial (Kwon, Heflin \& Ruef, 2013). However, research has also dealt with some knowledge disadvantages. For example, Ahuja (2000) found that the more a firm spanned structural holes, the fewer the firm's subsequent patents, as brokerage undermines interfirm trust. Fleming, Mingo, and Chen (2007b) found that collaborative brokerage resulted in new patents, but hampered their diffusion.

In addition to brokerage benefits based on access to non-redundant resources (primarily information), researchers have looked at brokerage benefits based on control of resources. For some, control of resources provides the theoretical link between brokerage and power (Brass, 1984). Because brokers control information flows among a large and diverse set of actors, they are perceived as more influential (Shipilov \& Li, 2008) and exert this influence over other actors 
(Padgett \& Ansell, 1993). Thus, carried to the extreme, brokerage can undermine the cooperation and feelings of trust and goodwill (McEvily \& Zaheer, 1999). Indeed, the Achilles' heel of a brokerage structure is that it does not inherently encourage — and sometimes even discourages - $\mathrm{a}$ willingness to cooperate. In contrast, closure, often seen as the opposite of brokerage, is typically associated with cooperation and trust (Coleman, 1988).

\section{Moderators of Brokerage}

As Burt (2010: 195) notes, "Network brokerage is a craft more than a commodity so benefits typically vary widely between people." Our review of the brokerage literature revealed a large set of seemingly unrelated moderators of the brokerage-outcomes relationship. However, when considering the conceptual rationale for each moderator, we discovered two underlying themes. Specifically, brokerage is more successful when (1) heterogeneous resources that result from bridging different social circles are effectively handled, and (2) trust develops between the broker and alters.

Researchers have identified a number of moderators at multiple levels that facilitate handling heterogeneous, asymmetric, and complex resources. At the broker level, brokerage becomes more beneficial when a broker has the skills to mobilize political support through negotiations, compromises, and horse trading, as brokering heterogeneous information across differing perspectives, opinions, or values typically involves both social and political skills (Grosser et al., 2018). This has been studied empirically in such diverse settings as HIV/AIDS treatment advocacy (Maguire, Hardy \& Lawrence, 2004), new entrepreneurial firms (Fang, Chi, Chen \& Baron, 2015), and the Nashville country music industry (Lingo \& O’Mahony, 2010).

At the task level, researchers have looked at the effects of knowledge heterogeneity, asymmetry, and complexity on brokerage outcomes. While some studies found that brokerage 
becomes increasingly important for tasks involving heterogeneous knowledge (Balachandran \& Hernandez, 2018), other research finds the opposite results (Ter Wal, Alexy, Block \& Sandner, 2016) as brokers fail to absorb effectively the diverse and heterogeneous knowledge they access. Knowledge asymmetry between the broker and the alters can also be a moderator, as the broker should perform better when the alter holds more inaccurate knowledge of the structural hole and thus does not threaten to exit the brokerage tie (Hahl, Kacperczyk \& Davis, 2016). Others have studied the knowledge complexity of a task. From the perspective of a broker, complex knowledge is more challenging, not just to transmit, but also to recombine into an existing knowledge base (Fleming et al., 2007b).

Brokerage moderators that focus on an organization's ability to handle heterogeneous resources include organizational endowments (Shi, Sun \& Peng, 2012), institutional order (Batjargal et al., 2013), generalist vs. specialist strategies (Shipilov, 2006), and absorptive capacity (Shipilov, 2009). Environmental turbulence, such as technological changes, can also play a moderating role. When the external environment changes only to a limited extent, firms with many structural holes in their alliance network perform better, because these brokers are well positioned to create novel recombinations of knowledge to take advantage of these changes (Koka \& Prescott, 2008). However, in the wake of a more radical environmental change, such broker firms are disadvantaged, as their alters may no longer "have the requisite information necessary for quick and effective strategic response" (Koka \& Prescott, 2008: 639).

The second moderator theme - trust and cooperation between broker and alters - is evident when considering the moderating effect of the strength of brokerage ties (Vedres, 2017), an effect due not so much to increased interaction frequency or emotional closeness but to trust (Levin et al., 2016). In particular, strong ties are better bridges than weak ties under two conditions. First, 
when social resources (e.g., trust and cooperation) must be transferred through network bridges, strong bridges are more valuable. Thus, when considering open innovation communities (Fleming \& Waguespack, 2007) or job referrals (Bian, 1997), strong ties mitigate an inherent lack of trust associated with brokerage positions. Second, the more the total amount of non-redundant information transmitted over the network, the more valuable strong ties are in providing access to novel information relative to weak ties (McFadyen, Semadeni \& Cannella Jr, 2009).

Although closure is often seen as the opposite of brokerage, the two can be viewed as complementary forms of social capital (Adler \& Kwon, 2002). Several streams of network studies support this view. Brokerage ties alone, although conducive to the generation of new ideas, might not be effective in implementation. The literature on "small world" networks, defined as clustered relationships connected via a few bridging ties, also suggests that dense internal ties combined with trusted bridging ties across clusters can be an effective enhancer of the value of brokerage (Fleming et al., 2007a). The literature on structural folding - the network feature of a cohesive group whose membership overlaps with that of another cohesive group - echoes a similar point (de Vaan, Stark \& Vedres, 2015). Because actors at the structural fold are insiders to multiple groups, they can create trust between groups by vouching within one group for the members of another and can thus hold groups in place until new kinds of creative combinations can emerge. All these studies suggest that brokerage is most productive where network closure within the group is high and many bridging ties exist beyond the group (Burt, 2005).

This focus on trust and cooperation extends to a broker's social identity as well. Brokers typically work with a diverse set of actors, so they tend to have flexible social identities (Reagans \& Zuckerman, 2008). Although brokers are sometimes sought out (Brass, 2009), they may not want to publicize their identities as "middlemen" because potential alters want to avoid the 
commissions, either monetary or influence, associated with brokerage ties (Burt, 1992). Brokers' power may also diminish if they are overtly identified with pursuing their own interests (Fernandez-Mateo, 2007). However, if a broker's identity as a broker is known only to the broker, then the broker is "free to engage in different behaviors in different groups, changing her colors as she moves from group to group" (Krackhardt, 1999: 207) and maintaining "cooperation and passivity on behalf of all alters" (Buskens \& van de Rijt, 2008: 373). Alternatively, some brokers cultivate an identity as a neutral mediator (Fleming \& Waguespack, 2007). Fernandez and Gould (1994) discuss the impartial third's capacity to mediate conflict and restore a group to a more harmonious state. Failure to maintain impartiality, though, can hurt the broker's reputation (Fleming \& Waguespack, 2007). Research has yet to explore the possibility that brokers may want to publicize their connections and successful brokering in order to acquire more brokerage opportunities.

At the organizational level, the extent to which the interests among employees are convergent can be an important moderator of brokerage's impact. In organizations where networks are highly fragmented and an "us-them" mentality emerges, actors who bridge conflicting social worlds often face distrust and suspicion about their loyalties from alters on both sides of the divide (Krackhardt, 1999). Under such circumstance, brokerage hurts, rather than benefits, the broker (Barnes, Kalberg, Pan \& Leung, 2016). Rogan (2014) applies this insight to a multiplex triad"triplets composed of actors playing different roles and interconnected by more than one kind of relationship" (Shipilov \& Li, 2012: 472-473) — and finds that, when a broker exits, the multiplex triad is more likely to dissolve if the triad's members are competitors and their interests diverge. Davis and Eisenhardt (2011) suggest that, for brokerage to be truly collaborative in an interdependent and dynamic environment such as the high technology industry, there must be a 
governance process that is much more fluid and collaborative.

Organizational and national culture have been viewed as influencing trust in brokers, although the research findings are mixed. Goldberg et al. (2016) found that brokers are more likely to be successful in their organization if they culturally fit with their colleagues. They argue that such "assimilated brokers" enjoy the advantages of acceptance and trust within the organization, as well as the informational benefits of brokerage. Focusing on national culture, Burt and colleagues found the consistent performance effect of brokerage across countries by replicating the positive brokerage effect among French (Burt et al., 2000) and Chinese (Burt \& Burzynska, 2017) managers. On the other hand, Wang (2015), Batjargal (2010), and Xiao and Tsui (2007) found that some cultures can be more hostile and xenophobic to brokers than others when compared to countries with collaborative norms (Vasudeva, Zaheer \& Hernandez, 2013). If brokerage is more beneficial in certain national cultures, is a brokerage advantage transferable from one culture to another? Guler and Guillen's (2010) research suggests no, supporting the idea that a firm's brokerage advantage is context-specific and difficult to transfer.

\section{Brokerage Dynamics}

Although the dominant structural approach to brokerage carries an underlying assumption of stability (where recurring interaction leads to structure), researchers have begun to view brokerage from a more dynamic, longitudinal perspective. These studies tend to build and/or test theories that look at the time-varying aspects of brokerage structure and behavior. Absent some exogenous shock, networks can change incrementally as actors join and leave, and in the case of brokerage, disconnections between alters can vanish (or appear). Can the broker advantage be maintained in the face of network change? We found a few brokerage articles that focused on such temporal changes. 
The focus on the persistence and decay of brokerage opportunities began with Burt's (2002) four-year study of bankers' networks showing that brokerage ties decay quickly. His findings are consistent with a mirror image of Krackhardt's (1998: 24) finding that particularly resistant to decay are Simmelian ties, i.e., when two actors "are reciprocally and strongly tied to each other and [also] to at least one third party in common." Several reasons could explain the rapid decay of brokerage ties. Stovel, Golub, and Milgrom (2011) list three possibilities. First, since many bridging ties are weak ties, they are easily disconnected. Second, a broker may be a conflicted actor experiencing role conflict from at least two different, disconnected actors. Third, the opportunity for a broker to extract excess gains from information asymmetries erodes confidence in the broker. Decay may also occur because the broker and alters tend to come from different social circles and do not share mutual acquaintances who can intervene if the dyadic relationship deteriorates (Feld, 1997). Decay may also be a function of adding many bridging ties and thereby making the network too dense and closed. Gulati, Sytch, and Tatarynowicz (2012) found that, as an industry matures, brokerage ties eventually saturate the space between clusters, making clusters more and more interconnected and making brokerage opportunities rarer. Consistent with balance theory (Heider, 1958), such triadic closure is most likely if actors have positive ties with the broker (Sytch \& Tatarynowicz, 2014) and are not competing for resources with the broker (Zhelyazkov, 2018).

Despite the notion of rapid decay, research has also shown that the presence of brokerage ties in the past best predicts the formation of current brokerage ties, just as past network closure predicts current closure (Kleinbaum, 2018). This could result from brokers continuing to add nonoverlapping ties to their networks (Sasovova et al., 2010) and/or by cutting redundant ties (Jonczyk, Lee, Galunic \& Bensaou, 2016), or, in the case of closure, by introducing any new ties to their 
current ties in a closed network. Perhaps as a result, Sasovova et al. (2010) found that some of the structural holes at the earlier period had been closed by the later period (7.5\%), some remained open (13\%), and a much larger number of new structural holes (i.e., brokerage ties) came into existence.

One source of such persistence in brokerage networks might come from brokering behavior (Obstfeld, 2005). Tertius separans behavior maintains the status quo by keeping alters apart, while tertius iungens behavior closes some structural holes, though at the same time generates a social momentum for new ties and thus new structural holes. Another source of persistence in brokerage networks can come from a "time-delayed brokerage" process in which knowledge mobilized through one tie can later become a relevant resource to be brokered via another tie. Such time delays could involve ties going dormant (Levin, Walter \& Murnighan, 2011), especially if the most valuable such ties are reconnected (Walter, Levin \& Murnighan, 2015) or if the memories of those ties are strong (Levin \& Walter, 2018). Time-delayed brokerage could also involve active ties where previously transmitted or yet-to-be transmitted knowledge is dormant.

The persistence and decay of brokerage ties matter because the performance effects of brokerage may vary with the age of the ties comprising a network. For example, the performance benefits of a broker's ties decrease with their age, as brokerage ties are often short-lived and prone to conflict by opportunism (Stovel et al., 2011). If a long-term tie develops in a brokerage network, the broker's return is diminished as the alters become less dependent on the broker (Bidwell \& Fernandez-Mateo, 2010). In contrast, the performance benefits of closure (non-brokerage) ties increase with their age, as it may take time to build the closure advantages of trust and integration. Thus, Baum et al. (2012) recommend a hybrid network position comprising a mixture of both types of ties - combining trust benefits from old closure ties and brokerage benefits from new brokerage 
ties - to get the maximum benefits. Consistent with this recommendation, in examining the sequencing of brokerage behavior by individuals, Burt and Merluzzi (2016) found that actors who oscillated over time between a closure strategy within groups and a brokerage strategy between groups got higher returns than those who stayed with one network strategy. They argue that the closure strategy provides both insider knowledge and trust that subsequently allow the broker to create brokerage ties to new groups. Their results reinforce the importance of examining brokerage dynamics in future research.

\section{INSIGHTS FOR FUTURE RESEARCH}

Despite the abundance of studies on brokerage, our review revealed important research gaps $(\mathrm{RG})$, which raise promising opportunities for future research. Drawing on the categories of the integrative framework in Figure 1, we examine these opportunities with the aim of identifying future research directions (FRD) as summarized in Table 1.

Insert Table 1 about here

\section{Opportunities for Future Research on Brokerage Structure}

Most of the studies we reviewed used ego-network measures of brokerage such as Burt's (1992) constraint index or effective size (RG1). Although this ego-network approach has proven useful, mapping the broader social structure in which personal networks are embedded may enrich our understanding of brokerage. Thus, we see a need for future research to extend the structural analysis to include the whole network within which the open triad occurs (FRD1). The research on secondhand brokerage reinforces the need to consider ties beyond the triad, including both brokerage and non-brokerage ties. For example, looking beyond direct ties raises the possibility that more than one broker may exist between two disconnected alters. An alternative broker 
changes the power dynamics, as the two disconnected alters have an alternative path for the flow of resources, making it harder for either broker to play one alter off against the other or extract payment for facilitating the flow of resources or for connecting the two alters.

Extending brokerage analysis to the larger network raises the question of how network centrality-i.e., being connected to a large number of actors in a network-plays a role in becoming a broker. For instance, some scholars (e.g., Nerkar \& Paruchuri, 2005) find that centrally located brokers (relative to peripherally located brokers) are perceived as important leaders with more access to resources controlled by other actors. By having a large number of contacts in the network, a central broker will likely be more aware of brokerage opportunities than peripheral brokers and become the "broker of choice" for alters. Central brokers may acquire a reputation for the efficient flow of resources and become activity hubs, the "go to" brokers for getting things done.

Moreover, we see a need to design future studies that explicitly consider whole-network structure, such as small-world and core-periphery structures, as the context within which brokerage occurs. Most of the studies we reviewed implicitly assumed a small-world structure, i.e., densely connected clusters with a few bridges connecting different clusters; hence the theoretical emphasis on obtaining non-redundant information. However, a focus on core-periphery structures suggests a shift in theory, focusing on the assumed quality or value of the resources/information possessed by alters. Core-periphery structures result from a few actors - often higher status - connected to each other at the core, with peripheral actors connected to the core but not to each other. This type of network structure makes it easy for the core elite to broker the peripheral actors, and the reverse, difficult. Thus, the overall structure of the network and actors' position in that structure may affect brokerage behavior and outcomes. 
Our review revealed that brokerage has been investigated mostly at a single level of analysis (RG2). However, following our prior suggestion to extend the structural approach to consider additional ties of brokers and alters, we see a need for multilevel research to understand the cross-level influences among individuals, groups, organizations, and communities, and their effects (FRD2). For example, Fernandez and Gould's (1994) study of different brokerage roles shows how the higher-level group affiliations of both the broker and the alters influence their brokerage roles. We also note that alters can be linked by brokers at different levels of analysis, i.e., individuals can be brokered by organizations (Small, 2006), or groups can be brokered by individuals (Kemeny, Feldman, Ethridge \& Zoller, 2016). Indeed, brokers can be influenced by cross-pressures from the different groups to which they belong (Tasselli \& Kilduff, 2018). Building on this, we can explore how a lower-level network (i.e., presence of a brokerage tie between individuals) affects outcomes at a higher level (i.e., group/organization cooperation). Brokerage can have an essential role in connecting the micro and macro levels of analysis, where individual network strategies may coalesce with the emergence of public goods and social integration at the higher level.

In the future, we expect growing interest in the exploration of brokerage microfoundations, unpacking the brokering interactions and reactions of micro-level entities-such as the beliefs, values, norms, and heuristics of brokers and alters - to explain macro-level phenomena. Research has recently started analyzing the multilevel implications of brokerage, observing that it may be beneficial to a group by bringing in new ideas and solutions (Fleming et al., 2007b), but manifest negative consequences for individual brokers or alters within the group (Bizzi, 2013). Ibarra, Kilduff \& Tsai (2005: 367) suggested examining when "the individual pursuit of network advantage detracts from or contributes to the emergence of public [collective] goods." For 
example, broker firms in geographical clusters are less likely to participate in and contribute to regional institutions that provide collective support services to firms in the region, as they are concerned about leakage of proprietary information via these regional institutions (McEvily \& Zaheer, 1999). Though individual and collective advantage can coalesce, little research has explored how this tension is managed (see Lingo \& O’Mahony, 2010 for an exception). We can also examine cross-level moderator models for situations in which a construct at one level of analysis influences the strength/direction of the causal links between constructs at another level. Combining measures at different levels, researchers might ask how brokerage at the individual level within the group interacts with the centralization of the group to affect important outcomes such as individual power. Although possible, such analyses have rarely been undertaken (see Paruchuri, 2010; Sasidharan, Santhanam, Brass \& Sambamurthy, 2012, for exceptions).

While the discussion above is focused on cross-level influences, our review indicated that multilevel perspective can benefit brokerage research done at a single level of analysis, too. We found that studies of interpersonal and interorganizational brokerage networks have used the same theoretical motivations and explanations, with an implicit assumption that actors, whether they be individuals, groups, or organizations (or communities), could be theoretically treated the same. For example, both Obstfeld (2005) and Ahuja (2000) study how brokerage influences innovation, but the former at the individual level and the latter at the firm level. The assumption is that access and control of resources have the same brokerage benefits regardless of level of analysis. While the abstract nature of actors and ties in network analysis may allow for such broad application of concepts and measures, the question of whether individual, group, and organizational brokerage is isomorphic across levels remains unaddressed, and research on brokerage as behavior may provide insights. For example, brokering intent may look very different for firms than for individuals. We 
see need for future research to look for when, why, and how brokerage does (or does not) manifest consistently across the different levels of analysis. Empirical investigations and validation of the assumption that brokerage is the same across levels have been largely absent (Moliterno \& Mahony, 2011).

Our review of research revealed that brokerage has been mostly examined in terms of network structure, largely overlooking the content of brokerage ties (RG3), with such information typically relegated to the methods sections of the manuscripts (see Borgatti, Brass \& Halgin, 2014, for more on network content and context). However, as Aral and Van Alstyne (2011: 95) suggest, "networks are not simply pipes into different pools of information; they reflect the nature of the relationships, interactions, and information exchanges taking place among those they connect." Thus, we encourage scholars to explore the content of brokerage ties (FRD3). For example, brokerage involving ties that provide task advice differs in important ways from brokerage involving ties providing political support, emotional support, career advice, or price information, to name just a few (e.g., Podolny \& Baron, 1997). Moreover, as we have noted, relationships often involve multiple types of connections, and brokers and alters may be connected or disconnected depending on the type of network content studied. For example, network ties might seem closed/dense with few brokerage ties in one context (e.g., professional ties), but seem open/sparse with many structural holes in another context (e.g., friendship ties). So the network can be interpreted as open or closed depending on the content of the ties (Obstfeld et al., 2014). Yet, in our review, even among the studies that take into account the content of ties (e.g., Podolny \& Baron, 1997), we found few examples of multiplex (i.e., multiple content) brokerage ties.

Furthermore, brokering disconnected ties of one sort (e.g., friendship) may affect connected ties of another sort (e.g., coworker). For example, it may be difficult to broker 
disconnected alters on one type of tie when they have connections on other types of ties; they would likely close the structural hole. Although the "middleman" position of the broker can foster distrust in some competitive or cultural environments, if brokers have multiple content ties (i.e., multiplex ties) to each alter, alters may perceive a broker as more trustworthy, alleviating any need to hide their brokerage. The broker, in turn, may also be less likely to act opportunistically, to prevent the loss of a multiplex tie (Brass, Butterfield \& Skaggs, 1998).

We also see a need for understanding the emotional content of ties, particularly negative ties, between alters, as well as between broker and alters. For example, the nature of a "lack of a tie" between alters can be ambiguous. Among the important research questions, there is a need to explore if alters are unaware of each other, if they are simultaneously connected and disconnected depending on the content, whether their disconnection involves a negative tie or a negative tie that had previously been positive, or is the tie simply dormant (Levin et al., 2011). The answers to such questions are likely to substantially change the conceptualization of both brokerage behavior and outcomes. The role of negative ties in brokerage is thus still ambiguous and researching it may unearth new mechanisms that diverge significantly from current knowledge about brokerage structures.

\section{Opportunities for Future Research on Brokerage Behavior}

The cognitive aspects or assumptions of brokerage behavior, such as variations in awareness and intentionality, have received little attention (RG4), as most reviewed studies conceptualize brokerage as an instrumental and intended behavior that actors deliberately undertake when presented with a brokerage opportunity. Yet, intentionality and awareness cannot be taken for granted and we see a need for exploring their role in brokerage (FRD4). Clearly, we cannot assume behavioral agency/strategy on the part of the broker if the broker is unaware of the 
brokerage opportunity. Understanding the role of actors' intentions, as well as exploring their absence, offers fruitful opportunities for future research. For instance, researchers could consider combining a broker's lack of intention to broker and alters' lack of awareness. More generally, there is a need to disentangle opportunity, awareness, and intent. Relatedly, existing research has not explicitly considered that brokering behavior may be motivated by different purposes. Moving beyond the tertius iungens or tertius separans (gaudens) behaviors may shed light on the reasons that spur brokers to behave as they do. Research on brokerage motivation could unpack the causes of alternative patterns of brokerage and their underlying dynamics, perhaps using methodologies not typically associated with networks scholarship, such as qualitative research. Thus, we see a need to disentangle how the intention to broker is related to the ability to broker, and how the broker's purpose in brokering affects brokerage and its underlying dimensions, as these are crucial yet still unaddressed questions.

Prior research on brokerage as behavior has paid predominant attention to the broker, overlooking the other actors, internal and external to the triad (RG5). However, the focus on brokerage behavior needs to move beyond a simple "keep them separated or bring them together" dichotomy employed by a broker and recognize the agency of the alters, the role of actors external to the triad, and situations where a broker is also an alter (FRD5). For example, scholars could investigate if alters seek out brokers for their convenience, for referrals, or when the disconnect involves distrust of the other alter (Brass, 2009). Alters may continue to use a broker who has successfully satisfied their needs in the past, or build ties to other alters when they distrust the broker or simply want to "cut out the middleman." Alters may not realize another actor's position as broker, that they themselves are being brokered, or understand the goal or consequences of such brokerage (Fernandez-Mateo, 2007). Future research might thus examine the impact of "brokerage 
visibility"-as perceived by alters as well as by outside third parties — on various outcomes, including reputation, trust, and the willingness to engage in future exchanges. For example, do actors seek out a broker after seeing the broker, or other brokers, provide positive outcomes to other alters?

Building on the observations collected from our literature review, we see the need to explore the simultaneous roles of an actor as both broker and alter. For example, each time a broker reaches out to a new alter not connected to any of the broker's other ties, this new alter also may act as a broker between the new alter's contacts and the original broker (Brass, 2009). Thus, when the study's scope is extended to measure the extended network structure and/or position within the whole network, every actor in a brokerage relationship could be considered structurally both broker and alter, and structural measures and statistical analyses would treat them similarly. The broker/alter distinction is only contingent on one's frame of reference as to which actor is considered the focal actor. This suggests the need to focus on the behavior of both the broker and the alters.

Perhaps it is the brokering-i.e., how each actor behaves in response to a given brokerage opportunity—that distinguishes actors in such cases. As our review shows, brokerage can often be beneficial to both broker and alters. More generally, scholars could analyze the "mutual benefit" that an alter and broker achieve by brokering. Of course, the exception to mutual benefit is when brokerage occurs in the context of mutually exclusive exchange partners (Cook \& Emerson, 1978) such as choosing one vender over another. As Borgatti and Halgin (2011) note, brokerage involving the choice of one alter, to the exclusion of the other, does not easily fit the typical network flow model implicitly invoked in network research (nor does the excluded alter appear in the data). Their suggestion of an alternative model, labeled the bond model, focuses on power, 
dependency, and mutual exclusion, and emphasizes the importance of considering the broader network context. Similarly, Kilduff and Brass (2010) note the importance of considering differences in cooperative vs. competitive contexts. Adopting a brokerage perspective that considers a wider range of actors, beyond the broker, has the potential to advance current understanding of how brokerage behavior unfolds.

\section{Opportunities for Future Research on Brokerage Antecedents}

A key finding from our review is that most investigated antecedents focus on the drivers of brokerage structure, analyzing the causes of network configuration and occupation of a brokerage position, with little attention directed to the antecedents of brokerage behavior (RG6). Thus, we see a need to further explore the drivers of brokerage behavior (FRD6). For instance, much of the research on brokerage antecedents originates with the assumption that a broker builds ties to disconnected alters. Janicik and Larrick (2005) and Burt and Ronchi (2007) illustrate this approach, as does research on self-monitoring. However, some brokers are assigned their structural position, rather than striving to occupy it. For example, managers in organizations often inherit a brokerage role between subordinates and superiors, with accompanying authority and required brokerage responsibilities. While most network methodologies for capturing brokerage structure do not differentiate between deliberate and assigned brokerage behaviors, we note that this form of assigned brokerage may differ considerably from the typically assumed deliberate brokerage of most existing studies. Although managers may readily accept their brokerage roles, brokerage antecedents that foster deliberate versus assigned brokerage may substantially affect brokerage behavior and outcomes. Moreover, we encourage future scholars to investigate different drivers of brokerage that have been neglected by prior research and have undergone a major transformation in recent years. For instance, online social media platforms like Facebook, LinkedIn, and Twitter 
could shape the antecedents of brokerage, either by creating more opportunities to bridge across previously unconnected actors or, conversely, by increasing pressures to eliminate brokerage by bringing everyone together. Furthermore, while there is a good deal of individual-level correlational data from which to infer antecedents of network connections (Brass, 2012), less attention has been directed to the same antecedents on different brokerage dimensions or to previously unexamined antecedents, e.g., at the group or organizational level.

\section{Opportunities for Future Research on Brokerage Outcomes}

Although almost all the reviewed studies included an outcome, we note that prior research has focused predominantly on economic and knowledge outcomes, with limited research attention devoted to possible affective and relational outcomes (RG7). Thus, we see a need for research on a broader set of outcomes of brokerage to help identify the meaning of a "successful brokerage" (FRD7), potentially redefined as the satisfaction of all actors involved in brokerage. For instance, for a broker, success might be achieving not only economic aims but also having the alters not feeling frustrated or exploited. Examining noneconomic outcomes that are negative-e.g., feeling morally impure (Casciaro, Gino \& Kouchaki, 2014), less satisfied (Bizzi, 2013), or lonely when brokering - might also shed light on why some actors occupying a broker position decide not to take advantage of brokerage opportunities. For alters, avoiding exploitation by a broker including feeling betrayed by having their secrets divulged—is clearly important.

Another major direction for future research concerns exploring the "optimal level" of brokerage. For instance, we encourage scholars to investigate the economic and noneconomic effects of "too much" brokerage - for either the broker or the alters - to see if there is an optimal level of brokerage for individuals, groups, and/or organizations.

\section{Opportunities for Future Research on Brokerage Moderators}


Prior research has adopted a restricted approach by conceptualizing and testing moderating factors affecting only the causal link between brokerage and outcomes, largely ignoring moderators of the causal link between brokerage antecedents and brokerage (RG8). Thus, we see a need to expand the scope of moderators to develop a deeper understanding of the factors that shape the antecedents-brokerage link (FRD8). For instance, future research might explain why actors with the same antecedents, such as certain personality traits, are not necessarily equally likely to be in a broker position or to engage easily and quickly in brokerage behavior. Moreover, future research could explore the moderating factors that enhance or diminish the impact of antecedents on a broker's ability and willingness to engage in matchmaking or to develop multiplex relationships in the network. Recent technologies such as social media, big data, and analytics may facilitate the identification - and amplify the reach — of potential brokering of disconnected alters. Thus, we encourage future scholars to understand how such technologies may influence the causal link between brokerage antecedents and brokerage.

\section{Opportunities for Future Research on Brokerage Dynamics}

Finally, our review revealed a largely static analytic approach adopted to investigate brokerage (RG9). This conception of brokerage as occurring only once in time and space has led to interesting findings but has left brokerage persistence and recurrence largely unexplored (see Sasovova et al., 2010 for an exception). Thus, we see a need to consider the implications of repeated brokerage on the same or new connections (FRD9). There is a need to explore the influence of an actor's prior brokerage experiences on new instances of brokerage and how adopting brokerage many times across the same ties (one-time versus repeated-times brokerage) influences brokerage and its outcomes. For instance, we call for future research aimed at detecting the presence of reciprocity mechanisms (e.g., information/resources sharing) that allow the broker 
to keep good relations with alters over time, or understanding the effect of temporal and situational factors of brokerage (e.g., global and national crises, external threats/environmental jolts, stages of economic development, industry/firm/human lifecycle stage, declining performance). Moreover, multiple brokerage initiatives can occur simultaneously and/or in sequence, and we see a need to explore the differences between these two types of occurrences as well as the circumstances and conditions that lead an actor to undertake either of them. In this regard, we also see the need for further investigation of "time-delayed brokerage" by exploring how past information and knowledge mobilized through one tie can later become relevant resources to be brokered via another tie.

\section{Methodological and Empirical Challenges}

Of course, embracing a dynamic, longitudinal approach to investigate brokerage implies methodological and empirical challenges. The few studies that sought to grasp brokerage dynamics relied mainly on archival data such as email logs (Quintane \& Carnabuci, 2016), user data scraped from Facebook (Wimmer \& Lewis, 2010), or co-membership networks among musical production teams (Uzzi \& Spiro, 2005) or TV production teams (Zaheer \& Soda, 2009). We encourage scholars to increasingly draw on these and other types of asynchronous digital communications (e.g., online blogs and web forums). For aspects of brokerage ties that involve perceptions or memory, however, such archival measures of (possibly forgotten or unobserved) activities may be less relevant (Levin \& Walter, 2018); in such cases, traditional survey-based approaches for collecting longitudinal data may be more appropriate. However, we acknowledge the difficulties of collecting longitudinal primary data adopting such traditional data sources. One promising development is the use of visual network scales (Mehra et al., 2014), which can reduce substantially the burden on survey respondents. In addition, we call for alternative approaches to 
supplement the existing data and methods that are widely diffused in prior research. Using novel data sources, like wearable sensors, (Ingram \& Morris, 2016), may be particularly useful for understanding brokerage dynamics among multiple actors (brokers, alters, and others), especially in networking events such as exhibitions or trade association meetings. In addition, we see the potential of conducting longitudinal brokerage studies by using data on crowdsourcing, a particular form of brokerage involving dispersed individuals who collaborate in finding the solution to a given problem by contributing knowledge skills and expertise that are not present within the organizational boundaries (e.g., Roth, 2015).

Future research may also usefully employ qualitative approaches for in-depth eventhistories, action-formation mechanisms, and further understanding of why and how processes and dynamics related to brokerage unfold. For example, multiple-case studies are useful for comparing different brokerage processes and building theory on the causal links that explain the emerging outcome variation. Ethnographic approaches and process studies can be employed for understanding the emergence, transformation, and adaptation of brokerage over time. Discourse studies are suitable to analyze the narrative development that shape the actions, meaning, and interactions of brokerage actors (e.g., analyses of speech or written communication patterns). Such qualitative approaches would also be useful in mixed-method research designs, either to complement and contextualize the insights gathered from quantitative studies (e.g., Uzzi, 1997), or to develop hypotheses for subsequent quantitative testing (e.g., Vissa, 2012). In addition, experimental methods - whether in the field, lab, or online - may also be useful in understanding the micro-dynamics of brokerage tie formation, behavior, maintenance, and dissolution, including allowing researchers to isolate the causal mechanisms involved.

Finally, simulations (e.g., agent-based models) examine the emergent outcomes of the 
dynamics of simultaneously interacting rule-based micro agents (i.e., broker and alters), to account for a particular observed brokerage outcome, such as the broker's control and access to resources. As such, simulations are particularly useful for understanding the bottom-up emergence of brokerage, modelling aggregation as it unfolds over time. Experimental approaches may be especially useful for understanding top-down (treatment) effects. For instance, such approaches can be particularly promising for exploring the affective and cognitive foundations of brokerage behavior. Counterfactual approaches and related modeling techniques (e.g., Bayesian narratives, causal graphs, and counterfactual testing and evaluation; cf. Morgan \& Winship, 2015) can be used to advance current understanding of causation in brokerage dynamics and to clarify how brokerage outcomes are achieved. Counterfactual approaches can be applied both in qualitative and quantitative analyses. In addition, causal modeling can help to re-conceptualize the influences between actors, resources, and outcomes in a temporal perspective. For example, causal modeling may help to disentangle whether the use of specific resources will enable the pursuit of a specific brokerage behavior or, on the other hand, whether the decision to execute a particular brokerage behavior will determine a specific way of using a resource. Moreover, qualitative comparative analysis (QCA) can prove particularly powerful for the counterfactual analysis of causal complexity (Greckhamer, Fumari, Fiss \& Aguilera, 2018), as it involves different combinations of causal conditions capable of generating the same outcome. Accordingly, it may be useful to identify and compare different configurations of brokerage structure and behavior and to understand how changes in such configurations would result in similar brokerage outcomes. There are other methods as well (e.g., time-series analytics, topic modelling, tensor decomposition) that might also be helpful to researchers focusing on brokerage dynamics. In sum, pursuing future research to advance the brokerage literature has the potential to expand both the types of data we 
use as well as the methods we adopt.

\section{CONCLUSION}

To help advance the field's understanding of network brokerage, we first reviewed studies of brokerage and then developed an integrative framework. By integrating the insights from our literature review, we provide a focused set of suggestions for future research. We suggest that brokerage research has advanced considerably since the pioneering work of Burt (1992) and others, and our hope is that our efforts to integrate the knowledge generated by dispersed streams of literature is beneficial in advancing understanding of the brokerage concept and related phenomena. Indeed, there remain many opportunities for management and other social science researchers to engage more fully with network brokerage, from a theoretical, empirical, and practical standpoint. 


\section{REFERENCES}

Adler, P. S., \& Kwon, S. W. 2002. Social capital: Prospects for a new concept. Academy of Management Review, 27(1): 17-40.

Afuah, A. 2013. Are network effects really all about size? The role of structure and conduct. Strategic Management Journal, 34(3): 257-273.

Ahuja, G. 2000. Collaboration networks, structural holes, and innovation: A longitudinal study. Administrative Science Quarterly, 45(3): 425-455.

Aral, S., \& Van Alstyne, M. 2011. The diversity-bandwidth trade-off. American Journal of Sociology, 117(1): 90-171.

Bae, J. H., \& Gargiulo, M. 2004. Partner substitutability, alliance network structure, and firm profitability in the telecommunications industry. Academy of Management Journal, 47(6): 843-859.

Baker, W. E., \& Obstfeld, D. 1999. Social capital by design: Structures, strategies, and institutional context. In R. T. A. J. Leenders and S. M. Gabbay (Eds.), Corporate social capital and liability: 88-105. Boston, MA: Kluwer Academic.

Balachandran, S., \& Hernandez, E. 2018. Networks and innovation: Accounting for structural and institutional sources of recombination in brokerage triads. Organization Science, 29(1): 80-99.

Barnes, M., Kalberg, K., Pan, M., \& Leung, P. 2016. When is brokerage negatively associated with economic benefits? Ethnic diversity, competition, and common-pool resources. Social Networks, 45: 55-65.

Batjargal, B. 2010. The effects of network's structural holes: Polycentric institutions, product portfolio, and new venture growth in China and Russia. Strategic Entrepreneurship Journal, 4(2): 146-163.

Batjargal, B., Hitt, M. A., Tsui, A. S., Arregle, J. L., Webb, J. W., \& Miller, T. L. 2013. Institutional polycentrism, entrepreneurs' social networks, and new venture growth. Academy of Management Journal, 56(4): 1024-1049.

Baum, J. A. C., McEvily, B., \& Rowley, T. J. 2012. Better with age? Tie longevity and the performance implications of bridging and closure. Organization Science, 23(2): 529-546.

Bian, Y. J. 1997. Bringing strong ties back in: Indirect ties, network bridges, and job searches in China. American Sociological Review, 62(3): 366-385.

Bidwell, M., \& Fernandez-Mateo, I. 2010. Relationship duration and returns to brokerage in the staffing sector. Organization Science, 21(6): 1141-1158.

Bizzi, L. 2013. The dark side of structural holes: A multilevel investigation. Journal of Management, 39(6): 1554-1578.

Boari, C., \& Riboldazzi, F. 2014. How knowledge brokers emerge and evolve: The role of actors' behaviour. Research Policy, 43(4): 683-695.

Borgatti, S. P., Brass, D. J., \& Halgin, D. S. 2014. Social network research: Confusions, criticisms, and controversies. In D. J. Brass, G. Labianca, A. Mehra, D. S. Halgin and S. P. Borgatti (Eds.), Research in the sociology of organizations, 40: 1-32. Bradford, UK: Emerald.

Borgatti, S. P., \& Halgin, D. S. 2011. On network theory. Organization science, 22(5): 11681181.

Borgatti, S. P., Mehra, A., Brass, D. J., \& Labianca, G. 2009. Network analysis in the social sciences. Science, 323(5916): 892-895. 
Brass, D. J. 1984. Being in the right place: A structural analysis of individual influence in an organization. Administrative Science Quarterly, 29(4): 518-539.

Brass, D. J. 2009. Connecting to brokers: Strategies for acquiring social capital. In V. O. Bartkus and J. H. Davis (Eds.), Social capital: Reaching out, reaching in: 260-274. Cheltenham, UK: Edward Elgar Publishing.

Brass, D. J. 2012. A social network perspective on organizational psychology. In S. W. J. Kozlowski (Ed.), The Oxford Handbook of Organizational Psychology: 667-695. New York, NY: Oxford University Press.

Brass, D. J., Butterfield, K. D., \& Skaggs, B. C. 1998. Relationships and unethical behavior: A social network perspective. Academy of Management Review, 23(1): 14-31.

Burt, R. forthcoming. Structural holes: capstone, cautions, and enthusiasms. In M. L. Small, B. L. Perry, B. Pescosolido and N. Smith (Eds.), Personal Networks: Classic Readings and New Directions: Cambridge University Press.

Burt, R. S. 1980. Models of network structure. Annual Review of Sociology, 6(1): 79-141.

Burt, R. S. 1983. Corporate profits and cooptation: Networks of market constraints and directorate ties in the American economy. New York, NY: Academic Press.

Burt, R. S. 1992. Structural holes: The social structure of competition. Cambridge, MA: Harvard University Press.

Burt, R. S. 1997. The contingent value of social capital. Administrative Science Quarterly, 42(2): 339-365.

Burt, R. S. 2002. Bridge decay. Social Networks, 24(4): 333-363.

Burt, R. S. 2004. Structural holes and good ideas. American Journal of Sociology, 110(2): 349399.

Burt, R. S. 2005. Brokerage and closure: An introduction to social capital. Oxford, UK: Oxford University Press.

Burt, R. S. 2007. Secondhand brokerage: Evidence on the importance of local structure for managers, bankers, and analysts. Academy of Management Journal, 50(1): 119-148.

Burt, R. S. 2010. Neighbor networks: Competitive advantage local and personal. Oxford: Oxford University Press.

Burt, R. S. 2012. Network-related personality and the agency question: Multirole evidence from a virtual world. American Journal of Sociology, 118(3): 543-591.

Burt, R. S. 2015. Reinforced structural holes. Social Networks, 43: 149-161.

Burt, R. S., \& Burzynska, K. 2017. Chinese entrepreneurs, social networks, and guanxi. Management and Organization Review, 13(2): 221-260.

Burt, R. S., Hogarth, R. M., \& Michaud, C. 2000. The social capital of French and American managers. Organization Science, 11(2): 123-147.

Burt, R. S., Kilduff, M., \& Tasselli, S. 2013. Social network analysis: Foundations and frontiers on advantage. Annual Review of Psychology, 64: 527-547.

Burt, R. S., \& Merluzzi, J. 2016. Network oscillation. Academy of Management Discoveries, 2(4): 368-391.

Burt, R. S., \& Ronchi, D. 2007. Teaching executives to see social capital: Results from a field experiment. Social Science Research, 36(3): 1156-1183.

Buskens, V., \& van de Rijt, A. 2008. Dynamics of networks if everyone strives for structural holes. American Journal of Sociology, 114(2): 371-407.

Carlile, P. R. 2004. Transferring, translating, and transforming: An integrative framework for managing knowledge across boundaries. Organization Science, 15(5): 555-568. 
Carpenter, M. A., Li, M. X., \& Jiang, H. 2012. Social network research in organizational contexts: A systematic review of methodological issues and choices. Journal of Management, 38(4): 1328-1361.

Casciaro, T., Gino, F., \& Kouchaki, M. 2014. The contaminating effects of building instrumental ties: How networking can make us feel dirty. Administrative Science Quarterly, 59(4): 705735 .

Castilla, E. J. 2005. Social networks and employee performance in a call center. American Journal of Sociology, 110(5): 1243-1283.

Chandler, D., Haunschild, P. R., Rhee, M., \& Beckman, C. M. 2013. The effects of firm reputation and status on interorganizational network structure. Strategic Organization, 11(3): 217-244.

Clement, J., Shipilov, A. V., \& Galunic, C. 2018. Brokerage as a public good: The externalities of network hubs for different formal roles in creative organizations. Administrative Science Quarterly, 63(2): 251-286.

Cook, K. S., \& Emerson, R. M. 1978. Power, equity and commitment in exchange networks. American Sociological Review, 43(5): 721-739.

Davis, J. P., \& Eisenhardt, K. M. 2011. Rotating leadership and collaborative innovation: Recombination processes in symbiotic relationships. Administrative Science Quarterly, 56(2): 159-201.

de Vaan, M., Stark, D., \& Vedres, B. 2015. Game changer: The topology of creativity. American Journal of Sociology, 120(4): 1144-1194.

Dougherty, D. 1992. Interpretive barriers to successful product innovation in large firms. Organization Science, 3(2): 179-202.

Ebbers, J. J. 2014. Networking behavior and contracting relationships among entrepreneurs in business incubators. Entrepreneurship Theory and Practice, 38(5): 1159-1181.

Fang, R., Chi, L., Chen, M. L., \& Baron, R. A. 2015. Bringing political skill into social networks: Findings from a field study of entrepreneurs. Journal of Management Studies, 52(2): 175-212.

Fang, R., Landis, B., Zhang, Z., Anderson, M. H., Shaw, J. D., \& Kilduff, M. 2015. Integrating personality and social networks: A meta-analysis of personality, network position, and work outcomes in organizations. Organization Science, 26(4): 1243-1260.

Feld, S. L. 1997. Structural embeddedness and stability of interpersonal relations. Social Networks, 19(1): 91-95.

Fernandez-Mateo, I. 2007. Who pays the price of brokerage? Transferring constraint through price setting in the staffing sector. American Sociological Review, 72(2): 291-317.

Fernandez, R. M., \& Gould, R. V. 1994. A dilemma of state power: Brokerage and influence in the national-health policy domain. American Journal of Sociology, 99(6): 1455-1491.

Fleming, L., King, C., \& Juda, A. 2007a. Small worlds and regional innovation. Organization Science, 18(6): 938-954.

Fleming, L., Mingo, S., \& Chen, D. 2007b. Collaborative brokerage, generative creativity, and creative success. Administrative Science Quarterly, 52(3): 443-475.

Fleming, L., \& Waguespack, D. M. 2007. Brokerage, boundary spanning, and leadership in open innovation communities. Organization Science, 18(2): 165-180.

Freeman, L. C. 1977. A set of measures of centrality based on betweenness. Sociometry, 40(1): $35-41$. 
Freeman, L. C. 1992. Filling in the blanks: A theory of cognitive categories and the structure of social affiliation. Social Psychology Quarterly, 55(2): 118-127.

Gangestad, S. W., \& Snyder, M. 2000. Self-monitoring: Appraisal and reappraisal. Psychological Bulletin, 126(4): 530-555.

Goldberg, A., Srivastava, S. B., Manian, V. G., Monroe, W., \& Potts, C. 2016. Fitting in or standing out? The tradeoffs of structural and cultural embeddedness. American Sociological Review, 81(6): 1190-1222.

Granovetter, M. S. 1973. The strength of weak ties. American Journal of Sociology, 78(6): 13601380.

Granovetter, M. S. 1974. Getting a job: A study of contacts and careers (1995, 2nd ed.). Chicago, IL: The University of Chicago Press.

Greckhamer, T., Fumari, S., Fiss, P., \& Aguilera, R. 2018. Studying configurations with qualitative comparative analysis: Best practices in strategy and organization research. Strategic Organization, 16(4): 482-495.

Grosser, T. J., Obstfeld, D., Choi, E. W., Woehler, M., Lopez-Kidwell, V., Labianca, G., \& Borgatti, S. P. 2018. A sociopolitical perspective on employee innovativeness and job performance: The role of political skill and network structure. Organization Science, 29(4): $612-632$.

Grosser, T. J., Obstfeld, D., Labianca, G., \& Borgatti, S. 2019. Measuring mediation and separation brokerage orientations: A further step toward studying the social network brokerage process. Academy of Management Discoveries, 5(2): 114-136.

Gulati, R., Sytch, M., \& Tatarynowicz, A. 2012. The rise and fall of small worlds: Exploring the dynamics of social structure. Organization Science, 23(2): 449-471.

Guler, I., \& Guillen, M. F. 2010. Home country networks and foreign expansion: Evidence from the venture capital industry. Academy of Management Journal, 53(2): 390-410.

Hahl, O., Kacperczyk, A., \& Davis, J. P. 2016. Knowledge asymmetry and brokerage: Linking network perception to position in structural holes. Strategic Organization, 14(2): 118-143.

Halevy, N., Halali, E., \& Zlatev, J. J. 2019. Brokerage and brokering: An integrative review and organizing framework for third party influence. Academy of Management Annals, 13(1): 215-239.

Hargadon, A. B. 2002. Brokering knowledge: Linking learning and innovation. In B. M. Staw and L. L. Cummings (Eds.), Research in organizational behavior, 24: 41-85. Greenwich, CT: JAI Press.

Hargadon, A. B., \& Sutton, R. I. 1997. Technology brokering and innovation in a product development firm. Administrative Science Quarterly, 42(4): 716-749.

Heider, F. 1958. The psychology of interpersonal relations. New York, NY: Wiley.

Hite, J. M., \& Hesterly, W. S. 2001. The evolution of firm networks: From emergence to early growth of the firm. Strategic Management Journal, 22(3): 275-286.

Ibarra, H., Kilduff, M., \& Tsai, W. 2005. Zooming in and out: Connecting individuals and collectivities at the frontiers of organizational network research. Organization Science, 16(4): 359-371.

Ingram, P., \& Morris, M. W. 2016. Do People Mix at Mixers? Structure, Homophily, and the "Life of the Party". Administrative Science Quarterly, 52(4): 558-585.

Janicik, G. A., \& Larrick, R. P. 2005. Social network schemas and the learning of incomplete networks. Journal of Personality and Social Psychology, 88(2): 348-364. 
Jonczyk, C. D., Lee, Y. G., Galunic, C. D., \& Bensaou, B. M. 2016. Relational changes during role transitions: The interplay of efficiency and cohesion. Academy of Management Journal, 59(3): 956-982.

Kalish, Y., \& Robins, G. 2006. Psychological predispositions and network structure: The relationship between individual predispositions, structural holes and network closure. Social Networks, 28(1): 56-84.

Kelley, H. H., \& Thibaut, J. W. 1978. Interpersonal relations: A theory of interdependence. New York: Wiley.

Kemeny, T., Feldman, M., Ethridge, F., \& Zoller, T. 2016. The economic value of local social networks. Journal of Economic Geography, 16(5): 1101-1122.

Kilduff, M., \& Brass, D. J. 2010. Organizational social network research: Core ideas and key debates. Academy of Management Annals, 4: 317-357.

Kirkels, Y., \& Duysters, G. 2010. Brokerage in SME networks. Research Policy, 39(3): 375-385.

Kleinbaum, A. M. 2012. Organizational misfits and the origins of brokerage in intrafirm networks. Administrative Science Quarterly, 57(3): 407-452.

Kleinbaum, A. M. 2018. Reorganization and tie decay choices. Management Science, 64(5): 1975-2471.

Kleinbaum, A. M., Jordan, A. H., \& Audia, P. G. 2015. An altercentric perspective on the origins of brokerage in social networks: How perceived empathy moderates the self-monitoring effect. Organization Science, 26(4): 1226-1242.

Koka, B. R., \& Prescott, J. E. 2008. Designing alliance networks: The influence of network position, environmental change, and strategy on firm performance. Strategic Management Journal, 29(6): 639-661.

Krackhardt, D. 1998. Simmelian ties: Super strong and sticky. In R. M. Kramer and M. A. Neale (Eds.), Power and influence in organizations: 21-38. Thousand Oaks, CA: Sage

Krackhardt, D. 1999. The ties that torture: Simmelian tie analysis in organizations. In S. B. Bacharach, S. B. Andrews and D. Knoke (Eds.), Research in the sociology of organizations, 16: 183-210. Stamford, CT: JAI Press.

Kwon, S. W., Heflin, C., \& Ruef, M. 2013. Community social capital and entrepreneurship. American Sociological Review, 78(6): 980-1008.

Landis, B., Kilduff, M., Menges, J. I., \& Kilduff, G. J. 2018. The paradox of agency: Feeling powerful reduces brokerage opportunity recognition yet increases willingness to broker. Journal of Applied Psychology, 103(8): 929-938.

Lee, G. K. 2007. The significance of network resources in the race to enter emerging product markets: The convergence of telephony communications and computer networking, 19892001. Strategic Management Journal, 28(1): 17-37.

Levin, D. Z., \& Walter, J. 2018. Is tie maintenance necessary? Academy of Management Discoveries, 4(4): 497-500.

Levin, D. Z., Walter, J., Appleyard, M. M., \& Cross, R. 2016. Relational enhancement: How the relational dimension of social capital unlocks the value of network-bridging ties. Group \& Organization Management, 41(4): 415-457.

Levin, D. Z., Walter, J., \& Murnighan, J. K. 2011. Dormant ties: The value of reconnecting. Organization Science, 22(4): 923-939.

Li, Y., Li, N., Guo, J., Li, J., \& Harris, T. B. 2018. A network view of advice-giving and individual creativity in teams: A brokerage-driven, socially perpetuated phenomenon. Academy of Management Journal, 61(6): 2210-2229. 
Lingo, E. L., \& O’Mahony, S. 2010. Nexus work: Brokerage on creative projects. Administrative Science Quarterly, 55(1): 47-81.

Maguire, S., Hardy, C., \& Lawrence, T. B. 2004. Institutional entrepreneurship in emerging fields: HIV/AIDS treatment advocacy in Canada. Academy of Management Journal, 47(5): 657-679.

Marsden, P. V. 1982. Brokerage behavior in restricted exchange networks. In P. V. Marsden and N. Lin (Eds.), Social structure and network analysis: 201-218. Beverly Hills, CA: Sage.

McDermott, G. A., Corredoira, R. A., \& Kruse, G. 2009. Public-private institutions as catalysts of upgrading in emerging market societies. Academy of Management Journal, 52(6): 12701296.

McEvily, B., Jaffee, J., \& Tortoriello, M. 2012. Not all bridging ties are equal: Network imprinting and firm growth in the Nashville legal industry, 1933-1978. Organization Science, 23(2): 547-563.

McEvily, B., \& Zaheer, A. 1999. Bridging ties: A source of firm heterogeneity in competitive capabilities. Strategic Management Journal, 20(12): 1133-1156.

McFadyen, M. A., Semadeni, M., \& Cannella Jr, A. A. 2009. Value of strong ties to disconnected others: Examining knowledge creation in biomedicine. Organization Science, 20(3): 552-564.

Mehra, A., Borgatti, S. P., Soltis, S., Floyd, T., Halgin, D. S., Ofem, B., \& Lopez-Kidwell, V. 2014. Imaginary worlds: Using visual network scales to capture perceptions of social networks. In D. J. Brass, G. Labianca, A. Mehra, D. S. Halgin and S. P. Borgatti (Eds.), Research in the Sociology of Organizations, 40: 315-336: Emerald Group Publishing Limited.

Mehra, A., Kilduff, M., \& Brass, D. J. 2001. The social networks of high and low self-monitors: Implications for workplace performance. Administrative Science Quarterly, 46(1): 121146.

Merton, R. K. 1957. Social theory and social structure. New York, NY: Free Press.

Mizruchi, M. S., \& Stearns, L. B. 2001. Getting deals done: The use of social networks in bank decision-making. American Sociological Review, 66(5): 647-671.

Moliterno, T. P., \& Mahony, D. M. 2011. Network theory of organization: A multilevel approach. Journal of Management, 37(2): 443-467.

Morgan, S. L., \& Winship, C. 2015. Counterfactuals and causal inference: Cambridge University Press.

Nerkar, A., \& Paruchuri, S. 2005. Evolution of R\&D capabilities: The role of knowledge networks within a firm. Management Science, 51(5): 771-785.

Obstfeld, D. 2005. Social networks, the tertius iungens orientation, and involvement in innovation. Administrative Science Quarterly, 50(1): 100-130.

Obstfeld, D., Borgatti, S. P., \& Davis, J. 2014. Brokerage as a process: Decoupling third party action from social network structure. In D. J. Brass, G. Labianca, A. Mehra, D. S. Halgin and S. P. Borgatti (Eds.), Research in the sociology of organizations, 40: 135-159. Bingley, UK: Emerald.

Owen-Smith, J., \& Powell, W. W. 2004. Knowledge networks as channels and conduits: The effects of spillovers in the Boston biotechnology community. Organization Science, 15(1): 5-21.

Pachucki, M. A., \& Breiger, R. L. 2010. Cultural holes: Beyond relationality in social networks and culture. Annual Review of Sociology, 36: 205-224. 
Padgett, J. F., \& Ansell, C. K. 1993. Robust action and the rise of the Medici, 1400-1434. American Journal of Sociology, 98(6): 1259-1319.

Paruchuri, S. 2010. Intraorganizational networks, interorganizational networks, and the impact of central inventors: A longitudinal study of pharmaceutical firms. Organization Science, 21(1): 63-80.

Phelps, C., Heidl, R., \& Wadhwa, A. 2012. Knowledge, networks, and knowledge networks: A review and research agenda. Journal of Management, 38(4): 1115-1166.

Podolny, J. M., \& Baron, J. N. 1997. Resources and relationships: Social networks and mobility in the workplace. American Sociological Review, 62(5): 673-693.

Pollock, T. G., Porac, J. F., \& Wade, J. B. 2004. Constructing deal networks: Brokers as network "architects" in the U.S. IPO market and other examples. Academy of Management Review, 29(1): 50-72.

Quintane, E., \& Carnabuci, G. 2016. How do brokers broker? Tertius gaudens, tertius iungens, and the temporality of structural holes. Organization Science, 27(6): 1343-1360.

Reagans, R., \& McEvily, B. 2003. Network structure and knowledge transfer: The effects of cohesion and range. Administrative Science Quarterly, 48(2): 240-267.

Reagans, R., \& Zuckerman, E. W. 2001. Networks, diversity, and productivity: The social capital of corporate R\&D teams. Organization Science, 12(4): 502-517.

Reagans, R. E., \& Zuckerman, E. W. 2008. Why knowledge does not equal power: the network redundancy trade-off. Industrial and Corporate Change, 17(5): 903-944.

Rogan, M. 2014. Executive departures without client losses: The role of multiplex ties in exchange partner retention. Academy of Management Journal, 57(2): 563-584.

Roth, Y. 2015. Crowdsourcing timeline. https://www.tikitoki.com/timeline/entry/52997/Crowdsourcing-by-Worlds-Best-Global-Brands/\#vars!date=5201552901-52910 52917:52948:52912.

Sapsed, J., Grantham, A., \& DeFillippi, R. 2007. A bridge over troubled waters: Bridging organisations and entrepreneurial opportunities in emerging sectors. Research Policy, 36(9): 1314-1334.

Sasidharan, S., Santhanam, R., Brass, D. J., \& Sambamurthy, V. 2012. The effects of social network structure on enterprise systems success: A longitudinal multilevel analysis. Information Systems Research, 23(3-part-1): 658-678.

Sasovova, Z., Mehra, A., Borgatti, S. P., \& Schippers, M. C. 2010. Network churn: The effects of self-monitoring personality on brokerage dynamics. Administrative Science Quarterly, 55(4): 639-668.

Sauder, M., Lynn, F., \& Podolny, J. M. 2012. Status: Insights from organizational sociology. Annual Review of Sociology, 38(1): 267-283.

Shah, N. P., Levin, D. Z., \& Cross, R. 2018. Secondhand social capital: Boundary spanning, secondhand closure, and individual performance. Social Networks, 52: 18-27.

Shi, W. L., Sun, S. L., \& Peng, M. W. 2012. Sub-national institutional contingencies, network positions, and IJV partner selection. Journal of Management Studies, 49(7): 1221-1245.

Shipilov, A. V. 2006. Network strategies and performance of Canadian investment banks. Academy of Management Journal, 49(3): 590-604.

Shipilov, A. V. 2009. Firm scope experience, historic multimarket contact with partners, centrality, and the relationship between structural holes and performance. Organization Science, 20(1): 85-106. 
Shipilov, A. V., \& Li, S. X. 2008. Can you have your cake and eat it too? Structural holes' influence on status accumulation and market performance in collaborative networks. Administrative Science Quarterly, 53(1): 73-108.

Shipilov, A. V., \& Li, S. X. 2012. The missing link: The effect of customers on the formation of relationships among producers in the multiplex triads. Organization Science, 23(2): 472491.

Simmel, G. 1950. The sociology of Georg Simmel. New York, NY: Free Press.

Small, M. L. 2006. Neighborhood institutions as resource brokers: Childcare centers, interorganizational ties, and resource access among the poor. Social Problems, 53(2): 274292.

Smith, S. S. 2005. "Don't put my name on it": Social capital activation and job-finding assistance among the black urban poor. American Journal of Sociology, 111(1): 1-57.

Soda, G., Tortoriello, M., \& Iorio, A. 2018. Harvesting value from brokerage: Individual strategic orientation, structural holes, and performance. Academy of Management Journal, 61(3): 896-918.

Spiro, E. S., Acton, R. M., \& Butts, C. T. 2013. Extended structures of mediation: Re-examining brokerage in dynamic networks. Social Networks, 35(1): 130-143.

Stam, W. 2010. Industry event participation and network brokerage among entrepreneurial ventures. Journal of Management Studies, 47(4): 625-653.

Stovel, K., Golub, B., \& Milgrom, E. M. M. 2011. Stabilizing brokerage. Proceedings of the National Academy of Sciences, 108(Supplement 4): 21326-21332.

Stovel, K., \& Shaw, L. 2012. Brokerage. Annual Review of Sociology, 38(1): 139-158.

Sytch, M., \& Tatarynowicz, A. 2014. Friends and foes: The dynamics of dual social structures. Academy of Management Journal, 57(2): 585-613.

Tasselli, S., \& Kilduff, M. 2018. When brokerage between friendship cliques endangers trust: A personality-network fit perspective. Academy of Management Journal, 61(3): 802-825.

Tasselli, S., Kilduff, M., \& Menges, J. I. 2015. The microfoundations of organizational social networks: A review and an agenda for future research. Journal of Management, 41(5): 1361-1387.

Ter Wal, A. L. J., Alexy, O., Block, J., \& Sandner, P. G. 2016. The best of both worlds: The benefits of open-specialized and closed-diverse syndication networks for new ventures' success. Administrative Science Quarterly, 61(3): 393-432.

Tortoriello, M., \& Krackhardt, D. 2010. Activating cross-boundary knowledge: The role of Simmelian ties in the generation of innovations. Academy of Management Journal, 53(1): $167-181$.

Uzzi, B. 1997. Social structure and competition in interfirm networks: The paradox of embeddedness. Administrative Science Quarterly, 42(1): 35-67.

Uzzi, B., \& Spiro, J. 2005. Collaboration and creativity: The small world problem. American Journal of Sociology, 111(2): 447-504.

van Wijk, J., Stam, W., Elfring, T., Zietsma, C., \& den Hond, F. 2013. Activists and incumbents structuring change: the interplay of agency, culture, and networks in field evolution. Academy of Management Journal, 56(2): 358-386.

Vasudeva, G., Zaheer, A., \& Hernandez, E. 2013. The embeddedness of networks: Institutions, structural holes, and innovativeness in the fuel cell industry. Organization Science, 24(3): 645-663. 
Vedres, B. 2017. Forbidden triads and creative success in jazz: The Miles Davis factor. Applied Network Science, 2(31): 1-25.

Vissa, B. 2012. Agency in action: Entrepreneurs' networking style and initiation of economic exchange. Organization Science, 23(2): 492-510.

Walter, J., Levin, D. Z., \& Murnighan, J. K. 2015. Reconnection choices: Selecting the most valuable (vs. most preferred) dormant ties. Organization Science, 26(5): 1447-1465.

Wang, C. L., Rodan, S., Fruin, M., \& Xu, X. Y. 2014. Knowledge networks, collaboration networks, and exploratory innovation. Academy of Management Journal, 57(2): 484-514.

Wang, D. 2015. Activating cross-border brokerage: Interorganizational knowledge transfer through skilled return migration. Administrative Science Quarterly, 60(1): 133-176.

Wimmer, A., \& Lewis, K. 2010. Beyond and below racial homophily: ERG models of a friendship network documented on Facebook. American Journal of Sociology, 116(2): 583642.

Xiao, Z. X., \& Tsui, A. S. 2007. When brokers may not work: The cultural contingency of social capital in Chinese high-tech firms. Administrative Science Quarterly, 52(1): 1-31.

Zaheer, A., \& Soda, G. 2009. Network evolution: The origins of structural holes. Administrative Science Quarterly, 54(1): 1-31.

Zhelyazkov, P. I. 2018. Interactions and interests: Collaboration outcomes, competitive concerns, and the limits to triadic closure. Administrative Science Quarterly, 63(1): 210-247. 
Table 1

Selected Opportunities for Future Research on Network Brokerage

\begin{tabular}{|c|c|c|c|}
\hline \multicolumn{2}{|c|}{$\begin{array}{cc}\text { Category } & \begin{array}{c}\text { Research Gaps } \\
\text { (RG) }\end{array} \\
\end{array}$} & \multicolumn{2}{|r|}{ Examples of Research Questions } \\
\hline \multirow{3}{*}{ 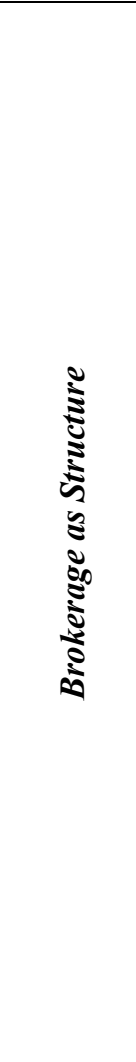 } & $\begin{array}{l}\text { RG1: } \\
\text { Brokerage examined } \\
\text { using the ego } \\
\text { network data and } \\
\text { measures }\end{array}$ & $\begin{array}{l}\text { FRD1: Expand the scope } \\
\text { to study the whole } \\
\text { network }\end{array}$ & $\begin{array}{l}\text { - What is the role of network centrality in becoming a broker? } \\
\text { - Are centrally located brokers in an advantage position as } \\
\text { compared to non-centrally located ones? } \\
\text { - What is the difference between small-world and core- } \\
\text { periphery structures in shaping brokerage behavior and } \\
\text { outcomes? }\end{array}$ \\
\hline & $\begin{array}{l}\text { RG2: } \\
\text { Brokerage mostly } \\
\text { investigated at single } \\
\text { level of analysis }\end{array}$ & $\begin{array}{l}\text { FRD2: Embrace } \\
\text { multilevel research to } \\
\text { understand the cross-level } \\
\text { influences among } \\
\text { individuals, groups, } \\
\text { organizations, and } \\
\text { communities, and their } \\
\text { effects }\end{array}$ & $\begin{array}{l}\text { - Can we assume that brokerage is the same at all levels of } \\
\text { analysis? If not, what are the different performance } \\
\text { implications of brokerage structure at different levels of } \\
\text { analysis (i.e., individual, group, organizational, community)? } \\
\text { How do performance effects at different levels related to each } \\
\text { other? } \\
\text { - What are the microfoundations of brokerage? How do actions } \\
\text { and interactions at the micro level of analysis and individuals' } \\
\text { characteristics (e.g., beliefs, values, heuristics, abilities, } \\
\text { motivations) influence macro-level brokerage processes and } \\
\text { outcomes? }\end{array}$ \\
\hline & $\begin{array}{l}\text { RG3: } \\
\text { Brokerage examined } \\
\text { mostly in terms of } \\
\text { network structure } \\
\text { (structuralist } \\
\text { perspective), } \\
\text { overlooking the } \\
\text { content of brokerage } \\
\text { ties }\end{array}$ & $\begin{array}{l}\text { FRD3. Explore the } \\
\text { content of brokerage ties }\end{array}$ & $\begin{array}{l}\text { - How does the content of ties (e.g., task advice, emotional } \\
\text { support, buyer/supplier) influence the brokerage structure? } \\
\text { - Does multiplexity (e.g., multiple content of ties) play a role? } \\
\text { How do a broker's multiple content ties (i.e., multiple ties) } \\
\text { affect the alters' perception of the broker's trustworthiness? } \\
\text { - How does the emotional content of ties between alters, as well } \\
\text { as between the broker and alters, affect their connections and } \\
\text { disconnections? For example, what is the role of negative ties } \\
\text { in brokerage? }\end{array}$ \\
\hline \multirow{2}{*}{ 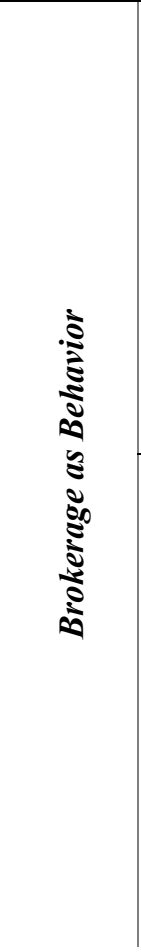 } & $\begin{array}{l}\text { RG4: } \\
\text { Brokerage conceived } \\
\text { merely as an } \\
\text { instrumental and } \\
\text { intended behavior, } \\
\text { overlooking } \\
\text { variation in } \\
\text { awareness and } \\
\text { intentionality }\end{array}$ & $\begin{array}{l}\text { FRD4: Explore the role of } \\
\text { intentionality and } \\
\text { awareness in brokerage }\end{array}$ & $\begin{array}{l}\text { - Can brokerage happen when the broker lacks the intention } \\
\text { and/or awareness to broker? When and under what conditions } \\
\text { does a broker unintendedly broker? What would brokerage } \\
\text { look like in such cases? } \\
\text { - How does brokerage unfold when the alters lacks intention } \\
\text { and/or awareness to be brokered? } \\
\text { - How is the intention to broker related to the ability to broker? } \\
\text { - Are different types of brokerage possible depending on } \\
\text { different degrees of intention and ability to broker? } \\
\text { - How do different brokerage purposes (and/or the lack of } \\
\text { purpose) influence brokerage and its underlying dimensions? }\end{array}$ \\
\hline & $\begin{array}{l}\text { RG5: } \\
\text { Broker regarded as } \\
\text { the predominant } \\
\text { focus in brokerage } \\
\text { examinations }\end{array}$ & $\begin{array}{l}\text { FRD5: Devote attention to } \\
\text { the alters in the triad, } \\
\text { alters external to the triad, } \\
\text { and brokers that are alters } \\
\text { in other triads }\end{array}$ & $\begin{array}{l}\text { - What can the alters do to avoid being exploited by a broker } \\
\text { and enhance their benefits? } \\
\text { - What other actors besides the broker play a role in shaping } \\
\text { brokerage, and how does taking into account such actors } \\
\text { change the current perspective adopted to study brokerage? } \\
\text { - Does observing a broker in action (i.e., brokerage visibility) } \\
\text { influence the perception by alters - outside the open triad- } \\
\text { about that broker or other brokers? } \\
\text { - When does a broker's new alter become broker of the tie } \\
\text { between the original broker and the new alter's own ties? } \\
\text { What are the mutual benefits that an alter and a broker achieve } \\
\text { by brokering? }\end{array}$ \\
\hline
\end{tabular}




\begin{tabular}{|c|c|c|c|}
\hline Category & $\begin{array}{l}\text { Research Gaps } \\
\text { (RG) }\end{array}$ & $\begin{array}{l}\text { Future Research } \\
\text { Directions (FRD) }\end{array}$ & Examples of Research Questions \\
\hline 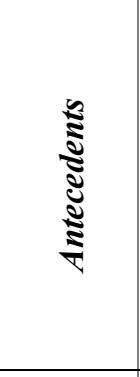 & $\begin{array}{l}\text { RG6: } \\
\text { Brokerage } \\
\text { antecedents mostly } \\
\text { linked to the } \\
\text { broker's position in a } \\
\text { network (i.e., mostly } \\
\text { related to the } \\
\text { structural dimension) }\end{array}$ & $\begin{array}{l}\text { FRD6: Explore the drivers } \\
\text { of brokerage behavior }\end{array}$ & $\begin{array}{l}\text { - What are the brokerage antecedents that foster deliberate } \\
\text { versus assigned brokerage? How do such antecedents affect } \\
\text { brokerage behavior and outcomes? } \\
\text { - Why do different actors undertake brokerage? What are the } \\
\text { different goals that brokers have when brokering? } \\
\text { - Under what circumstances are social media a source of } \\
\text { brokerage? } \\
\text { - What are the group- and organization-level antecedents of } \\
\text { brokerage behavior? }\end{array}$ \\
\hline 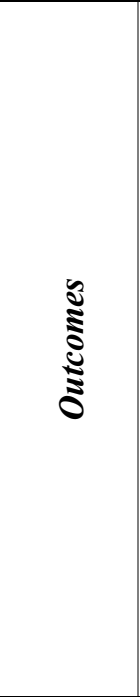 & $\begin{array}{l}\text { RG7: } \\
\text { Brokerage outcomes } \\
\text { mostly examined } \\
\text { from economic and } \\
\text { knowledge } \\
\text { perspectives }\end{array}$ & $\begin{array}{l}\text { FRD7: Encompass a } \\
\text { wider range of brokerage } \\
\text { outcomes, including } \\
\text { affective and relational } \\
\text { aspects }\end{array}$ & $\begin{array}{l}\text { - How should we conceptualize and measure "success" in } \\
\text { brokering? } \\
\text { - How do different types of brokerage outcomes affect each } \\
\text { other? Are there positive/negative complementary or } \\
\text { substitutive effects? } \\
\text { - What kind of affective (e.g., loneliness, anger) and relational } \\
\text { (e.g., changes in tie strength) outcomes result from brokerage? } \\
\text { - How do such outcomes affect different actors differently? } \\
\text { (e.g., energy depletion)? How do alters feel after being } \\
\text { unintentionally brokered? } \\
\text { - Is there a too-much-of-a-good-thing effect that reduces the } \\
\text { marginal benefits from brokering and/or triggers negative } \\
\text { consequences? } \\
\text { - To what extent does any optimal level of brokerage differ } \\
\text { among different types of individuals, groups, and/or } \\
\text { organizations? }\end{array}$ \\
\hline 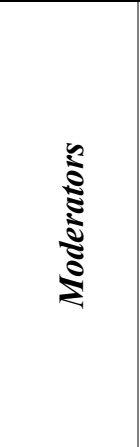 & $\begin{array}{l}\text { RG8: } \\
\text { Brokerage } \\
\text { moderators mostly } \\
\text { affecting the causal } \\
\text { link between } \\
\text { brokerage and } \\
\text { outcomes }\end{array}$ & $\begin{array}{l}\text { FRD8: Consider possible } \\
\text { moderators of the causal } \\
\text { link between brokerage } \\
\text { antecedents and brokerage }\end{array}$ & $\begin{array}{l}\text { - Are there moderators that affect the ease and/or speed of an } \\
\text { actor's becoming a broker or engaging in various brokerage } \\
\text { behaviors? } \\
\text { - What are the moderating factors that enhance or diminish the } \\
\text { impact of antecedents on a broker's ability and willingness to } \\
\text { develop multiplex ties in the network? } \\
\text { How do technologies influence the causal links between } \\
\text { brokerage antecedents and brokerage? E.g., how can social } \\
\text { media, big data, and analytics facilitate the identification-and } \\
\text { amplify the reach-of potential brokering of disconnected } \\
\text { alters? }\end{array}$ \\
\hline 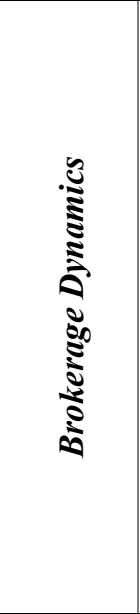 & $\begin{array}{l}\text { RG9: } \\
\text { Brokerage } \\
\text { considered as an } \\
\text { event or process that } \\
\text { happens only once }\end{array}$ & $\begin{array}{l}\text { FRD9: Analyze the } \\
\text { implications of repeated } \\
\text { brokerage on the same or } \\
\text { new connections }\end{array}$ & $\begin{array}{l}\text { - How do prior actors' brokerage experiences influence new } \\
\text { instances of brokerage? What are the implications of adopting } \\
\text { brokerage many times across the same ties (one-time vs } \\
\text { repeated-times brokerage)? } \\
\text { - Are there any reciprocity mechanisms (e.g., } \\
\text { information/resources sharing) that allow the broker to keep } \\
\text { good relations with alters over time? } \\
\text { - How do temporal and situational factors (e.g., global and } \\
\text { national crises, external threats/environmental jolts, stages of } \\
\text { economic development, industry/firm/human lifecycle stage, } \\
\text { declining performance) affect brokerage? } \\
\text { - When and how does an actor undertake multiple brokerage } \\
\text { initiatives simultaneously vs. in sequence? } \\
\text { - What changes when a broker transfers information collected } \\
\text { from an alter in the past to another alter in a different moment? }\end{array}$ \\
\hline
\end{tabular}


Figure 1

An Integrative Framework for Network Brokerage ${ }^{3}$

\begin{tabular}{|l}
\hline \\
Antecedents (38) \\
- Actor agency: \\
personality, \\
awareness, and status \\
- Organizational and \\
environmental context \\
\end{tabular}
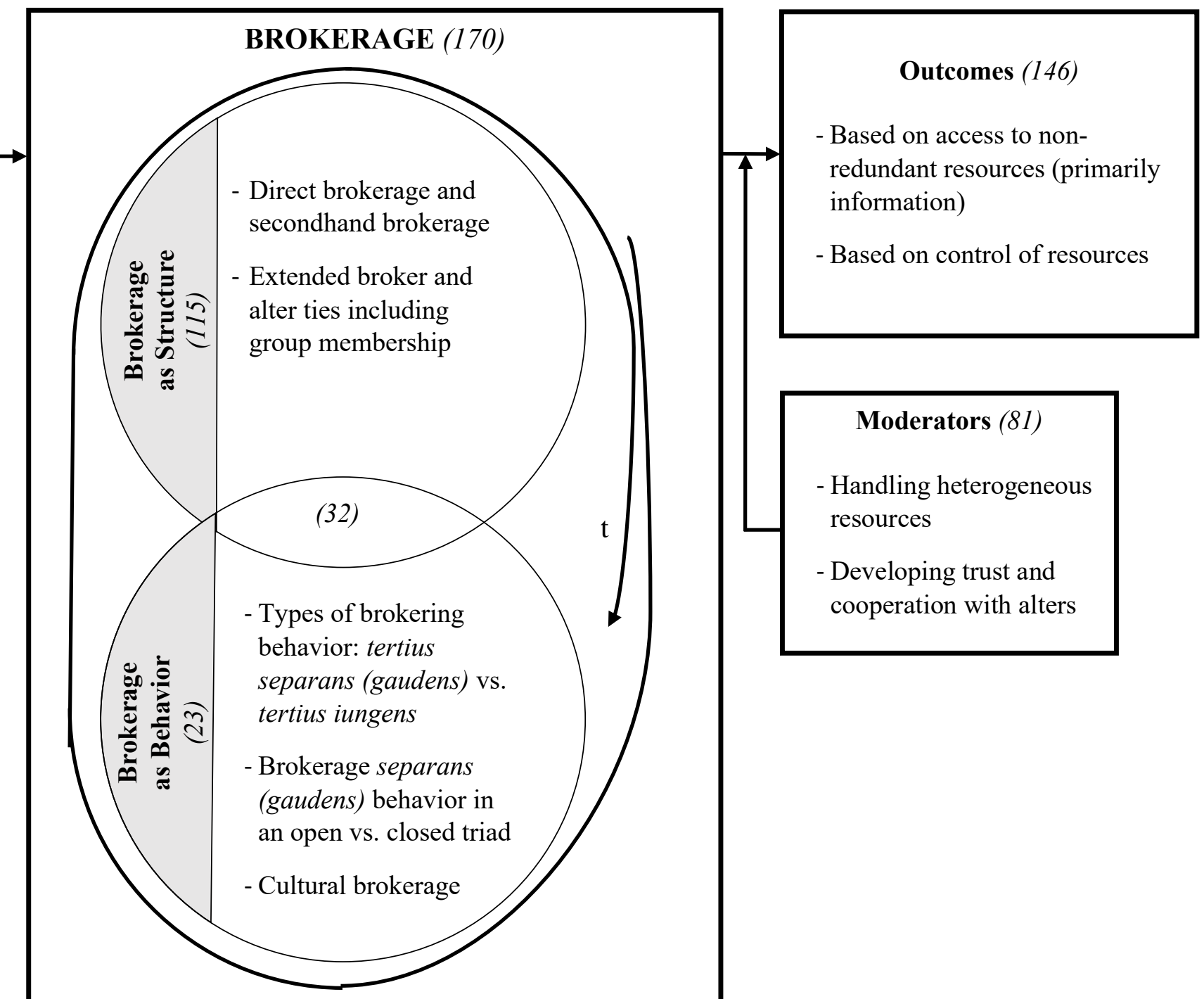

Brokerage Dynamics (28)

-Persistence and decay

\footnotetext{
${ }^{3}$ The number of articles in each category is in parentheses. The $t$ notation in the center refers to changes over time, i.e., brokerage dynamics.
} 


\section{ONLINE SUPPLEMENT TO}

\section{NETWORK BROKERAGE:}

\section{AN INTEGRATIVE REVIEW AND FUTURE RESEARCH AGENDA}

- Table S1: 170 Articles Examining Network Brokerage

- Figure S1: Article Review Methodology for "Network Brokerage" Literature

- Methodological Supplement 
NETWORK BROKERAGE 52

Table S1

170 Articles Examining Network Brokerage

\begin{tabular}{|c|c|c|c|c|c|c|c|}
\hline Author(s) & Research question(s) & $\begin{array}{l}\text { Level(s) of } \\
\text { analysis }\end{array}$ & $\begin{array}{c}\text { Categories of } \\
\text { factors }\end{array}$ & $\begin{array}{l}\text { Type of } \\
\text { article }\end{array}$ & Sample & Findings/Conclusions & Outcomes \\
\hline Afuah (2013) & $\begin{array}{l}\text { What is it about a } \\
\text { network that bestows } \\
\text { value on network } \\
\text { members? }\end{array}$ & $\begin{array}{l}\text { Individual, } \\
\text { Inter- } \\
\text { organization }\end{array}$ & $\mathrm{S}, \mathrm{B}, \mathrm{O}$ & Conceptual & 一. & $\begin{array}{l}\text { Besides a network's size, a network's } \\
\text { structure (feasibility of transactions, } \\
\text { centrality of members, structural } \\
\text { holes, network ties, the number of } \\
\text { roles each member plays) and its } \\
\text { conduct (opportunistic behavior, } \\
\text { reputation signaling, perceptions of } \\
\text { trust) also have significant impacts } \\
\text { on a network's value to users and to } \\
\text { network providers }\end{array}$ & $\begin{array}{l}\text { Value creation } \\
\text { and capture }\end{array}$ \\
\hline Ahuja (2000) & $\begin{array}{l}\text { How do a firm's direct } \\
\text { ties, indirect ties, and } \\
\text { structural holes influence } \\
\text { innovation outputs? }\end{array}$ & Organization & $\mathrm{S}, \mathrm{O}$ & $\begin{array}{l}\text { Empirical } \\
\text { quantitative }\end{array}$ & $\begin{array}{l}996 \text { firms in the chemicals } \\
\text { industry, 1981-1991 }\end{array}$ & $\begin{array}{l}\text { Increasing structural holes has a } \\
\text { negative effect on innovation. }\end{array}$ & $\begin{array}{l}\text { Innovation } \\
\text { outputs }\end{array}$ \\
\hline $\begin{array}{l}\text { Ahuja, Soda, } \\
\text { \& Zaheer } \\
(2012)\end{array}$ & $\begin{array}{l}\text { How and why do } \\
\text { organizational networks } \\
\text { emerge, evolve, and } \\
\text { change? }\end{array}$ & Organization & A, S, D & Conceptual & - & $\begin{array}{l}\text { Empirical research on network } \\
\text { dynamics is sparse. }\end{array}$ & - \\
\hline $\begin{array}{l}\text { Aldrich \& } \\
\text { Kim (2007) }\end{array}$ & $\begin{array}{l}\text { (1) What do networks } \\
\text { do? (2) How do social } \\
\text { networks arise? }\end{array}$ & Individual & $\mathrm{A}, \mathrm{S}, \mathrm{O}$ & Conceptual & - & $\begin{array}{l}\text { Mundane entrepreneurial teams arise } \\
\text { within localized clusters and appear } \\
\text { unlikely to take advantage of what } \\
\text { network theorists have called small } \\
\text { world networks, which depend upon } \\
\text { bridging ties between clusters. }\end{array}$ & $\begin{array}{l}\text { Entrepreneurial } \\
\text { team composition, } \\
\text { entrepreneurial } \\
\text { search }\end{array}$ \\
\hline $\begin{array}{l}\text { Aral \& Van } \\
\text { Alstyne (2011) }\end{array}$ & $\begin{array}{l}\text { At what rate do we } \\
\text { receive novelty from our } \\
\text { different social contacts? }\end{array}$ & Individual & $\mathrm{S}, \mathrm{O}, \mathrm{M}$ & $\begin{array}{l}\text { Empirical } \\
\text { quantitative }\end{array}$ & $\begin{array}{l}125,000 \text { e-mail messages } \\
\text { exchanged during } 10-12 \\
\text { months by } 73 \text { employees of } \\
\text { an executive recruiting firm } \\
\text { with } 14 \text { U.S. offices }\end{array}$ & $\begin{array}{l}\text { Channel bandwidth is positively } \\
\text { associated with receiving more } \\
\text { diverse information and more total } \\
\text { nonredundant information. }\end{array}$ & $\begin{array}{l}\text { The number and } \\
\text { the speed of } \\
\text { contract } \\
\text { fulfillment, } \\
\text { revenue generated } \\
\text { by a recruiter }\end{array}$ \\
\hline
\end{tabular}

\footnotetext{
${ }^{4}$ As reported in Figure 1 of the main article, the five categories of factors in our proposed framework are: $A=A n t e c e d e n t s, ~ S=B r o k e r a g e ~ a s ~ S t r u c t u r e, ~ B=$ Brokerage as Behavior, $\mathrm{O}=$ Outcomes, $\mathrm{M}=$ Moderators, $\mathrm{D}=$ Brokerage Dynamics.
} 
NETWORK BROKERAGE 53

\begin{tabular}{|c|c|c|c|c|c|c|c|}
\hline Author(s) & Research question(s) & $\begin{array}{l}\text { Level(s) of } \\
\text { analysis }\end{array}$ & $\begin{array}{c}\text { Categories of } \\
\text { factors }\end{array}$ & $\begin{array}{l}\text { Type of } \\
\text { article }\end{array}$ & Sample & Findings/Conclusions & Outcomes \\
\hline Baer (2010) & $\begin{array}{l}\text { How does openness to } \\
\text { experience interact with } \\
\text { idea network size, } \\
\text { strength, and diversity to } \\
\text { jointly impact creativity? }\end{array}$ & $\begin{array}{l}\text { Individual, } \\
\text { Intra- } \\
\text { organization }\end{array}$ & $\mathrm{S}, \mathrm{O}, \mathrm{M}$ & $\begin{array}{l}\text { Empirical } \\
\text { quantitative }\end{array}$ & $\begin{array}{l}216 \text { employees from a large, } \\
\text { global agricultural- } \\
\text { processing firm }\end{array}$ & $\begin{array}{l}\text { Networks of optimal size and weak } \\
\text { strength, even when they reach into } \\
\text { different social circles, do not foster } \\
\text { creativity unless actors are able to } \\
\text { take advantage of the opportunities } \\
\text { afforded by their networks. Openness } \\
\text { to experience is one personality } \\
\text { dimension critical if idea networks of } \\
\text { optimal size, weak strength, and high } \\
\text { diversity are to result in elevated } \\
\text { levels of creativity. }\end{array}$ & $\begin{array}{l}\text { Creativitiy } \\
\text { evaluated by } \\
\text { supervisors }\end{array}$ \\
\hline $\begin{array}{l}\text { Balachandran } \\
\text { \& Hernandez } \\
(2018)\end{array}$ & $\begin{array}{l}\text { How do structural and } \\
\text { institutional boundaries } \\
\text { influence the knowledge } \\
\text { recombination process of } \\
\text { innovation within a firm's } \\
\text { network? }\end{array}$ & $\begin{array}{l}\text { Organization, } \\
\text { Inter- } \\
\text { organization, } \\
\text { cross- } \\
\text { institution } \\
\text { (cross- } \\
\text { country } \\
\text { alliances) }\end{array}$ & $\mathrm{S}, \mathrm{O}, \mathrm{M}$ & $\begin{array}{l}\text { Empirical } \\
\text { quantitative }\end{array}$ & $\begin{array}{l}11,025 \text { alliances R\&D } \\
\text { alliances during 1985-2005 } \\
\text { (Database: Recombinant } \\
\text { Capital (Recap)) }\end{array}$ & $\begin{array}{l}\text { Brokerage of foreign triads expose } \\
\text { firms to high levels of novelty by } \\
\text { facilitating access to diverse sources } \\
\text { of institutionalized knowledge, } \\
\text { generating high costs of knowledge } \\
\text { integration. In contrast, brokerage of } \\
\text { domestic triads fosters high } \\
\text { efficiency in knowledge integration } \\
\text { but lower levels of novelty exposure. }\end{array}$ & $\begin{array}{l}\text { Innovation } \\
\text { volume (patent } \\
\text { counts) and } \\
\text { radicalness of the } \\
\text { firm's innovations } \\
\text { (patent citations) }\end{array}$ \\
\hline $\begin{array}{l}\text { Baldassarri \& } \\
\text { Diani (2007) }\end{array}$ & $\begin{array}{l}\text { (1) What is the shape of } \\
\text { civic networks in } \\
\text { democratic society? (2) } \\
\text { What types of ties may } \\
\text { contribute to the } \\
\text { strengthening and } \\
\text { integration of civil } \\
\text { society, and how? }\end{array}$ & Organization & $\mathrm{S}$ & $\begin{array}{l}\text { Empirical } \\
\text { mixed } \\
\text { methods }\end{array}$ & $\begin{array}{l}124 \text { organizations promoting } \\
\text { advocacy and interest } \\
\text { representation in Glasgow } \\
\text { and } 134 \text { in Bristol }\end{array}$ & $\begin{array}{l}\text { Relational mechanisms generate } \\
\text { networks tight enough to embed civic } \\
\text { associations in a distinctive } \\
\text { environment, but open enough to } \\
\text { connect them to a broader range of } \\
\text { civic organizations. }\end{array}$ & - \\
\hline $\begin{array}{l}\text { Barnes, } \\
\text { Kalberg, Pan, } \\
\text { \& Leung } \\
(2016)\end{array}$ & $\begin{array}{l}\text { When is brokerage } \\
\text { negatively associated } \\
\text { with economic benefits? }\end{array}$ & $\begin{array}{l}\text { Individual, } \\
\text { Inter- } \\
\text { organization }\end{array}$ & $\mathrm{S}, \mathrm{O}, \mathrm{M}$ & $\begin{array}{l}\text { Empirical } \\
\text { quantitative }\end{array}$ & $\begin{array}{l}\text { Multiple datasets from } \\
\text { Hawaii’s pelagic longline } \\
\text { fishery }\end{array}$ & $\begin{array}{l}\text { Brokerage defined both structurally } \\
\text { and qualitatively has a significantly } \\
\text { negative relationship with } \\
\text { productivity under conditions of } \\
\text { strong homophily and competition. }\end{array}$ & $\begin{array}{l}\text { Vessel captain } \\
\text { trip-level revenue }\end{array}$ \\
\hline
\end{tabular}


NETWORK BROKERAGE 54

\begin{tabular}{|c|c|c|c|c|c|c|c|}
\hline Author(s) & Research question(s) & $\begin{array}{l}\text { Level(s) of } \\
\text { analysis }\end{array}$ & $\begin{array}{c}\text { Categories of } \\
\text { factors }\end{array}$ & $\begin{array}{l}\text { Type of } \\
\text { article }\end{array}$ & Sample & Findings/Conclusions & Outcomes \\
\hline $\begin{array}{l}\text { Batjargal } \\
(2010)\end{array}$ & $\begin{array}{l}\text { 1) Do network's } \\
\text { structural holes affect } \\
\text { product development and } \\
\text { profit growth of new } \\
\text { ventures? 2) Do national } \\
\text { institutions (i.e., Chinese } \\
\text { versus Russian) moderate } \\
\text { the effect of structural } \\
\text { holes on the product } \\
\text { portfolios of new } \\
\text { ventures? 3) Do new } \\
\text { companies' product } \\
\text { portfolios moderate the } \\
\text { effect of structural holes } \\
\text { on profit growth? }\end{array}$ & $\begin{array}{l}\text { Individual, } \\
\text { Inter- } \\
\text { organization, } \\
\text { Cross- } \\
\text { country }\end{array}$ & $\mathrm{S}, \mathrm{B}, \mathrm{O}, \mathrm{M}$ & $\begin{array}{l}\text { Empirical } \\
\text { quantitative }\end{array}$ & $\begin{array}{l}\text { Telephone interview data of } \\
159 \text { entrepreneurs in Beijing } \\
\text { and Moscow }\end{array}$ & $\begin{array}{l}\text { Structural holes have a positive effect } \\
\text { on product portfolio and negative } \\
\text { main effect on profit growth in the } \\
\text { second revenue year, Due to the } \\
\text { polycentricity of institutions, } \\
\text { structural holes are more useful in the } \\
\text { Russian than Chinese institutional } \\
\text { context. }\end{array}$ & $\begin{array}{l}\text { Product portfolio } \\
\text { (the number of } \\
\text { product market } \\
\text { segments where } \\
\text { the firm sold } \\
\text { packaged software } \\
\text { products and } \\
\text { applications) and } \\
\text { profit growth (the } \\
\text { percentage of } \\
\text { profit growth in } \\
\text { the second } \\
\text { revenue year) }\end{array}$ \\
\hline $\begin{array}{l}\text { Batjargal, Hitt, } \\
\text { Tsui, Arregle, } \\
\text { Webb, \& } \\
\text { Miller (2013) }\end{array}$ & $\begin{array}{l}\text { What is the } \\
\text { interrelationship among } \\
\text { formal institutions, social } \\
\text { networks, and new } \\
\text { venture growth? }\end{array}$ & Individual & $\mathrm{A}, \mathrm{S}, \mathrm{O}, \mathrm{M}$ & $\begin{array}{l}\text { Empirical } \\
\text { quantitative }\end{array}$ & $\begin{array}{l}637 \text { entrepreneurs from four } \\
\text { countries }\end{array}$ & $\begin{array}{l}\text { The confluence of weak and } \\
\text { inefficient formal institutions is } \\
\text { associated with structural holes. A } \\
\text { network's structural holes have a } \\
\text { positive effect on revenue growth. } \\
\text { Furthermore, the positive effect of } \\
\text { structural holes on revenue growth is } \\
\text { stronger in an environment with } \\
\text { weaker and more inefficient } \\
\text { institutions. }\end{array}$ & $\begin{array}{l}\text { Venture } \\
\text { performance } \\
\text { (revenue growth) }\end{array}$ \\
\hline $\begin{array}{l}\text { Battilana \& } \\
\text { Casciaro } \\
(2012)\end{array}$ & $\begin{array}{l}\text { Under which conditions } \\
\text { can change agents } \\
\text { influence other } \\
\text { organizational members } \\
\text { to adopt changes? }\end{array}$ & Individual & $\mathrm{S}, \mathrm{O}$ & $\begin{array}{l}\text { Empirical } \\
\text { mixed } \\
\text { methods }\end{array}$ & $\begin{array}{l}68 \text { clinical managers in the } \\
\text { NHS and } 8 \text { in-depth case } \\
\text { studies }\end{array}$ & $\begin{array}{l}\text { Bridging structural holes exposes } \\
\text { change agents to initiate divergent } \\
\text { change and to adopt divergent } \\
\text { change. }\end{array}$ & $\begin{array}{l}\text { Organizational } \\
\text { change }\end{array}$ \\
\hline $\begin{array}{l}\text { Baum, } \\
\text { McEvily, \& } \\
\text { Rowley (2012) }\end{array}$ & $\begin{array}{l}\text { How does the } \\
\text { performance effects of } \\
\text { firm's network positions } \\
\text { vary with the ages of the } \\
\text { ties comprising those } \\
\text { positions? }\end{array}$ & $\begin{array}{l}\text { Organization, } \\
\text { Inter- } \\
\text { organization }\end{array}$ & $\mathrm{S}, \mathrm{O}, \mathrm{M}, \mathrm{D}$ & $\begin{array}{l}\text { Empirical } \\
\text { quantitative }\end{array}$ & $\begin{array}{l}\text { Underwriting syndicates } \\
\text { formed in investment banks } \\
\text { in Canada between 1950- } \\
1990 \text { (Database: Record of } \\
\text { new issues) }\end{array}$ & $\begin{array}{l}\text { The benefits associated with closure } \\
\text { take time to } \\
\text { develop, whereas those associated } \\
\text { with bridging are often (but not } \\
\text { exclusively) short lived. Closure and } \\
\text { bridging complement each other. }\end{array}$ & $\begin{array}{l}\text { Investment bank's } \\
\text { annual market } \\
\text { share }\end{array}$ \\
\hline
\end{tabular}


NETWORK BROKERAGE 55

\begin{tabular}{|c|c|c|c|c|c|c|c|}
\hline Author(s) & Research question(s) & $\begin{array}{l}\text { Level(s) of } \\
\text { analysis }\end{array}$ & $\begin{array}{c}\text { Categories of } \\
\text { factors }\end{array}$ & $\begin{array}{l}\text { Type of } \\
\text { article }\end{array}$ & Sample & Findings/Conclusions & Outcomes \\
\hline $\begin{array}{l}\text { Bessant \& } \\
\text { Rush (1995) }\end{array}$ & $\begin{array}{l}\text { What is the interactive } \\
\text { nature of the technology } \\
\text { transfer process, what are } \\
\text { the policy mechanisms } \\
\text { that enable it to proceed } \\
\text { effectively and what is } \\
\text { the role played by } \\
\text { consultants is this } \\
\text { process? }\end{array}$ & $\begin{array}{l}\text { Individual, } \\
\text { Organization }\end{array}$ & $\mathrm{B}, \mathrm{O}$ & Conceptual & - & $\begin{array}{l}\text { The technology transfer process is } \\
\text { interactive and complex, consultants } \\
\text { play an important role, there is no } \\
\text { single blueprint for the use of } \\
\text { consultants within technology } \\
\text { transfer programmes, and managing } \\
\text { such a complex process requires high } \\
\text { levels of managerial skills and } \\
\text { innovative capabilities on the part of } \\
\text { firms. }\end{array}$ & $\begin{array}{l}\text { Implications for } \\
\text { technology } \\
\text { transfer policy } \\
\text { (e.g., bandwagon } \\
\text { effect) }\end{array}$ \\
\hline Bian (1997) & $\begin{array}{l}\text { How do ties of differing } \\
\text { strengths affect } \\
\text { occupational attainment } \\
\text { when jobs are assigned } \\
\text { through the bureaucracy } \\
\text { of a state socialist } \\
\text { government? }\end{array}$ & Individual & $\mathrm{S}, \mathrm{O}, \mathrm{M}$ & $\begin{array}{l}\text { Empirical } \\
\text { quantitative }\end{array}$ & $\begin{array}{l}\text { Representative sample of } \\
1,008 \text { adult residents (ages } \\
18 \text { and older) in Tianjin, } \\
\text { China, } 1988\end{array}$ & $\begin{array}{l}\text { Jobs are acquired through strong ties } \\
\text { more frequently than through weak } \\
\text { ties in China. Job seekers and their } \\
\text { ultimate helpers are indirectly } \\
\text { connected through intermediaries to } \\
\text { whom both are strongly tied, and job } \\
\text { seekers using indirect ties are more } \\
\text { likely to obtain better jobs than those } \\
\text { using direct ties. }\end{array}$ & $\begin{array}{l}\text { Job Status } \\
\text { Attained from } \\
\text { Respondent's } \\
\text { Social Resources, } \\
\text { Use of Indirect } \\
\text { Tie to Helper and } \\
\text { the Strength of } \\
\text { Tie to Helper, } \\
\text { Whether Helper } \\
\text { Holds an } \\
\text { Administrative } \\
\text { Position, }\end{array}$ \\
\hline $\begin{array}{l}\text { Bian \& Ang } \\
\text { (1997) }\end{array}$ & $\begin{array}{l}\text { How do job changers } \\
\text { find helpers with high } \\
\text { social position through } \\
\text { ties of varying strength? } \\
\text { Do helpers at high levels } \\
\text { lead to better jobs for job } \\
\text { changers? }\end{array}$ & Individual & $\mathrm{S}, \mathrm{B}, \mathrm{O}$ & $\begin{array}{l}\text { Empirical } \\
\text { quantitative }\end{array}$ & $\begin{array}{l}\text { Two samples: (i) } 497 \text { job } \\
\text { changers from adult re- } \\
\text { spondents who had worked } \\
\text { in the civilian labor force in } \\
\text { Tianjin (China); (ii) } 348 \text { job } \\
\text { changers from a sample of } \\
512 \text { employees randomly } \\
\text { selected from eight major } \\
\text { industries in Singapore }\end{array}$ & $\begin{array}{l}\text { Jobs are channeled through strong } \\
\text { ties more frequently than through } \\
\text { weak, regardless of differences in } \\
\text { labor market contexts; when job } \\
\text { changers and their ultimate helpers } \\
\text { are unconnected, they tend to be } \\
\text { bridged through intermediaries to } \\
\text { whom both are strongly or } \\
\text { moderately rather than weakly tied; } \\
\text { helpers' job status has positive } \\
\text { impacts on job changers' attained job } \\
\text { status. }\end{array}$ & $\begin{array}{l}\text { Attained job status } \\
\text { (for job seekers) }\end{array}$ \\
\hline $\begin{array}{l}\text { Bidwell \& } \\
\text { Fernandez- } \\
\text { Mateo }(2010)\end{array}$ & $\begin{array}{l}\text { How do brokers create } \\
\text { and capture value from } \\
\text { their activities? }\end{array}$ & Individual & $\mathrm{S}, \mathrm{O}, \mathrm{M}$ & $\begin{array}{l}\text { Empirical } \\
\text { mixed } \\
\text { methods }\end{array}$ & $\begin{array}{l}49 \text { interviews and } \\
\text { longitudinal data on } 250 \\
\text { workers, placed in } 1464 \\
\text { projects across } 461 \text { clients } \\
\text { from the records of a single } \\
\text { staffing US firm in the } \\
\text { information technology (IT) } \\
\text { industry, }\end{array}$ & $\begin{array}{l}\text { Lon term relationships between } \\
\text { broker and counterparts enables } \\
\text { brokers to access private information } \\
\text { about buyers and sellers leading to } \\
\text { more valuable buyer-seller matches } \\
\text { and higher retention of the value } \\
\text { created through these matches. }\end{array}$ & $\begin{array}{l}\text { The transaction } \\
\text { price and the } \\
\text { proportion of the } \\
\text { transaction price } \\
\text { (percentage } \\
\text { margin) retained } \\
\text { by the broker }\end{array}$ \\
\hline
\end{tabular}


NETWORK BROKERAGE 56

\begin{tabular}{|c|c|c|c|c|c|c|c|}
\hline Author(s) & Research question(s) & $\begin{array}{l}\text { Level(s) of } \\
\text { analysis }\end{array}$ & $\begin{array}{c}\text { Categories of } \\
\text { factors }\end{array}$ & $\begin{array}{l}\text { Type of } \\
\text { article }\end{array}$ & Sample & Findings/Conclusions & Outcomes \\
\hline Bizzi (2013) & $\begin{array}{l}\text { How does the group } \\
\text { composition of individual } \\
\text { structural hole positions } \\
\text { affect individual } \\
\text { outcomes? }\end{array}$ & $\begin{array}{l}\text { Individual, } \\
\text { Group }\end{array}$ & $\mathrm{S}, \mathrm{O}, \mathrm{M}$ & $\begin{array}{l}\text { Empirical } \\
\text { quantitative }\end{array}$ & $\begin{array}{l}\text { Survey to supervisors and } \\
\text { employees in two } \\
\text { organizations in North } \\
\text { America (the first in the } \\
\text { pharmaceutical industry, } 138 \\
\text { respondents. The second in } \\
\text { the video games industry, } \\
152 \text { respondents) }\end{array}$ & $\begin{array}{l}\text { Individual- level structural holes may } \\
\text { be beneficial to individuals. } \\
\text { However, group-level mean and } \\
\text { group-level variance in structural } \\
\text { holes exercise deleterious effects on } \\
\text { individual outcomes. }\end{array}$ & $\begin{array}{l}\text { Individual } \\
\text { perception of } \\
\text { autonomy, } \\
\text { individual job } \\
\text { satisfaction, } \\
\text { individual } \\
\text { performance }\end{array}$ \\
\hline $\begin{array}{l}\text { Blyler \& Coff } \\
(2003)\end{array}$ & $\begin{array}{l}\text { Who benefits when a } \\
\text { firm has a dynamic } \\
\text { capability? }\end{array}$ & Individual & $\mathrm{S}, \mathrm{O}, \mathrm{M}$ & Conceptual & 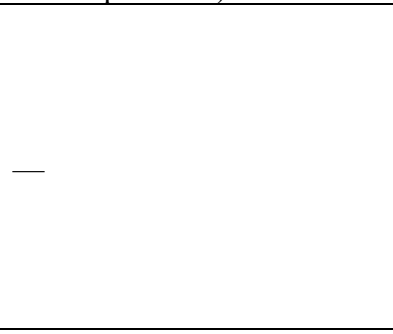 & $\begin{array}{l}\text { Structural hole is a key mechanism } \\
\text { enabling individuals to appropriate } \\
\text { rent within the specific context of a } \\
\text { firm with a dynamic capability. Such } \\
\text { ties are idiosyncratic, transitory and } \\
\text { may make individuals especially } \\
\text { mobile. Together, these effects } \\
\text { should grant individuals significant } \\
\text { power with which to appropriate rent. }\end{array}$ & $\begin{array}{l}\text { Appropriate rent } \\
\text { in a firm with a } \\
\text { dynamic } \\
\text { capability }\end{array}$ \\
\hline $\begin{array}{l}\text { Boari \& } \\
\text { Riboldazzi } \\
(2014)\end{array}$ & $\begin{array}{l}\text { How can actors } \\
\text { positioned in a network } \\
\text { evolve as knowledge } \\
\text { brokers, and how can } \\
\text { they act to develop new } \\
\text { brokerage roles? }\end{array}$ & Organization & S, B, D & $\begin{array}{l}\text { Empirical } \\
\text { qualitative }\end{array}$ & $\begin{array}{l}\text { Single case study on } 20 \text { years } \\
\text { of a small Italian comics } \\
\text { publishing house } \\
\text { (longitudinal interviews, } \\
\text { observations and archival } \\
\text { document) }\end{array}$ & $\begin{array}{l}\text { The use of shared imprinting between } \\
\text { a broker's entrepreneurial team and } \\
\text { receiving partners could enable its } \\
\text { transcoding function and therefore } \\
\text { sustain the emergence of any } \\
\text { brokerage role. Hiring new members } \\
\text { with diverse competences and } \\
\text { industry experience, with respect to } \\
\text { the founding team, by affecting the } \\
\text { firm's absorptive capacity, better } \\
\text { enables the firm to transcode and } \\
\text { transfer knowledge and thereby } \\
\text { fosters the exploration of new } \\
\text { brokerage roles. }\end{array}$ & - \\
\hline $\begin{array}{l}\text { Borgatti \& } \\
\text { Halgin (2011) }\end{array}$ & $\begin{array}{l}\text { What is network theory } \\
\text { and what is distinctive } \\
\text { about it? }\end{array}$ & $\begin{array}{l}\text { Individual, } \\
\text { Group, } \\
\text { Organization }\end{array}$ & $\mathrm{S}, \mathrm{O}$ & Conceptual & - & $\begin{array}{l}\text { Structural holes is a network theory } \\
\text { that considers network function of } \\
\text { the flow or distribution of } \\
\text { information. Different network } \\
\text { content produces different network } \\
\text { structures. }\end{array}$ & $\begin{array}{l}\text { Creativity, } \\
\text { likelihood of } \\
\text { promotion, getting } \\
\text { a job, etc. }\end{array}$ \\
\hline $\begin{array}{l}\text { Brands \& } \\
\text { Kilduff (2014) }\end{array}$ & $\begin{array}{l}\text { Do women face bias in } \\
\text { the social realm in which } \\
\text { they are purported to } \\
\text { excel? Is brokerage an } \\
\text { activity that is seen as } \\
\text { characteristically male? }\end{array}$ & Individual & $\mathrm{S}, \mathrm{O}, \mathrm{M}$ & $\begin{array}{l}\text { Empirical } \\
\text { quantitative }\end{array}$ & $\begin{array}{l}\text { Study 1: Survey on cognitive } \\
\text { social structure of } 33 \\
\text { individuals in the personnel } \\
\text { at the head office of Pacific } \\
\text { Distributors; Study 2: survey } \\
\text { on cognitive social structure } \\
\text { of } 110 \text { MBA students }\end{array}$ & $\begin{array}{l}\text { Gender stereotypes influence the } \\
\text { perception of social network roles, } \\
\text { resulting in schematic representations } \\
\text { of networks that exaggerate the } \\
\text { likelihood that men, relative to } \\
\text { women, will initiate ties and strive } \\
\text { for brokerage. }\end{array}$ & $\begin{array}{l}\text { Perceived } \\
\text { brokerage, } \\
\text { perceived warmth } \\
\text { and competence, } \\
\text { individual and } \\
\text { team performance }\end{array}$ \\
\hline
\end{tabular}


NETWORK BROKERAGE 57

\begin{tabular}{|c|c|c|c|c|c|c|c|}
\hline Author(s) & Research question(s) & $\begin{array}{l}\text { Level(s) of } \\
\text { analysis }\end{array}$ & $\begin{array}{c}\text { Categories of } \\
\text { factors }\end{array}$ & $\begin{array}{l}\text { Type of } \\
\text { article }\end{array}$ & Sample & Findings/Conclusions & Outcomes \\
\hline $\begin{array}{l}\text { Brass, } \\
\text { Butterfield, \& } \\
\text { Skaggs (1998) }\end{array}$ & $\begin{array}{l}\text { How do the ties among } \\
\text { actors influence unethical } \\
\text { behavior? }\end{array}$ & Individual & $\mathrm{S}, \mathrm{O}, \mathrm{M}$ & Conceptual & - & $\begin{array}{l}\text { Network ties and structure are related } \\
\text { to unethical behavior. }\end{array}$ & $\begin{array}{l}\text { Unethical } \\
\text { behavior }\end{array}$ \\
\hline $\begin{array}{l}\text { Briscoe \& } \\
\text { Rogan (2016) }\end{array}$ & $\begin{array}{l}\text { How does the internal } \\
\text { knowledge network can } \\
\text { compound or mitigate the } \\
\text { loss of a coordinating } \\
\text { manager? }\end{array}$ & Organization & $\mathrm{S}, \mathrm{O}, \mathrm{M}$ & $\begin{array}{l}\text { Empirical } \\
\text { quantitative }\end{array}$ & $\begin{array}{l}26,371 \text { client-year } \\
\text { observations in a law firm }\end{array}$ & $\begin{array}{l}\text { Heterogeneity and expertise of the } \\
\text { knowledge network increases, but } \\
\text { network cohesion reduces the firm's } \\
\text { dependence on individual brokers for } \\
\text { coordination of knowledge. }\end{array}$ & $\begin{array}{l}\text { Client relationship } \\
\text { performance } \\
\text { using the total } \\
\text { billable hours } \\
\text { charged to each } \\
\text { client } \\
\text { in a given year. }\end{array}$ \\
\hline $\begin{array}{l}\text { Briscoe \& } \\
\text { Tsai (2011) }\end{array}$ & $\begin{array}{l}\text { How does the } \\
\text { configuration of prior } \\
\text { referral relationships } \\
\text { influence new sharing of } \\
\text { clients undertaken by } \\
\text { individual partners? }\end{array}$ & Individual & $\mathrm{B}, \mathrm{O}, \mathrm{M}$ & $\begin{array}{l}\text { Empirical } \\
\text { mixed } \\
\text { methods }\end{array}$ & $\begin{array}{l}212 \text { individuals who were } \\
\text { partners in either the } \\
\text { acquiring firm or one of the } \\
\text { two acquired law firms }\end{array}$ & $\begin{array}{l}\text { The referral-network structures } \\
\text { contribute to integration by } \\
\text { increasing interunit sharing as well as } \\
\text { detract from integration by cutting } \\
\text { existing intraunit ties. Interunit client } \\
\text { sharing is positively associated with } \\
\text { revenue generation but negatively } \\
\text { associated with human capital } \\
\text { development. }\end{array}$ & $\begin{array}{l}\text { Client sharing, } \\
\text { cutting prior } \\
\text { intraunit sharing } \\
\text { ties, Revenue } \\
\text { generation, } \\
\text { Human capital } \\
\text { development }\end{array}$ \\
\hline Burt (1997) & $\begin{array}{l}\text { What is the network } \\
\text { structure of social capital } \\
\text { and evidence of social } \\
\text { capital's effect on } \\
\text { manager success? }\end{array}$ & Individual & $\mathrm{S}, \mathrm{O}, \mathrm{M}$ & $\begin{array}{l}\text { Empirical } \\
\text { quantitative }\end{array}$ & $\begin{array}{l}\text { Probability sample of } 170 \\
\text { senior managers at a large } \\
\text { electronics firm and a } \\
\text { manufacturing firm }\end{array}$ & $\begin{array}{l}\text { The information and control benefits } \\
\text { of bridging the structural holes are } \\
\text { especially valuable to managers with } \\
\text { few peers. }\end{array}$ & $\begin{array}{l}\text { Promotion and } \\
\text { bonus }\end{array}$ \\
\hline Burt (2000) & & $\begin{array}{l}\text { Individual, } \\
\text { Group }\end{array}$ & $\mathrm{S}, \mathrm{B}, \mathrm{O}, \mathrm{M}$ & $\begin{array}{l}\text { Conceptual } \\
\text { (review) }\end{array}$ & - & $\begin{array}{l}\text { Social capital is more a function of } \\
\text { brokerage across structural holes than } \\
\text { closure within a network, but there } \\
\text { are contingency factors. Structural } \\
\text { holes separate nonredundant sources } \\
\text { of information, sources that are more } \\
\text { additive than overlapping. }\end{array}$ & Performance \\
\hline
\end{tabular}


NETWORK BROKERAGE 58

\begin{tabular}{|c|c|c|c|c|c|c|c|}
\hline Author(s) & Research question(s) & $\begin{array}{l}\text { Level(s) of } \\
\text { analysis }\end{array}$ & $\begin{array}{c}\text { Categories of } \\
\text { factors }\end{array}$ & $\begin{array}{l}\text { Type of } \\
\text { article }\end{array}$ & Sample & Findings/Conclusions & Outcomes \\
\hline Burt (2002) & & $\begin{array}{l}\text { Individual, } \\
\text { Group }\end{array}$ & $\begin{array}{c}\mathrm{A}, \mathrm{S}, \mathrm{B}, \mathrm{O}, \mathrm{M}, \\
\mathrm{D}\end{array}$ & $\begin{array}{l}\text { Empirical } \\
\text { quantitative }\end{array}$ & $\begin{array}{l}\text { Social network of } 345 \\
\text { bankers from the investment } \\
\text { banking division of a large } \\
\text { financial organization over } 4 \\
\text { years }\end{array}$ & $\begin{array}{l}\text { Network bridges are critical to social } \\
\text { capital. Bridges relative to other } \\
\text { kinds of ties show faster rates of } \\
\text { decay over time, with implications } \\
\text { for the stability of social capital. } \\
\text { Maintaining a volume of network } \\
\text { bridges in an organization would } \\
\text { require hiring new people whose } \\
\text { initial relations within the } \\
\text { organization are by definition } \\
\text { bridges, until the new people also } \\
\text { settle in and have to be replaced with } \\
\text { new entrants. Bridge decay is } \\
\text { significantly less likely in the } \\
\text { networks of individuals who have } \\
\text { more experience with bridges, } \\
\text { therefore social capital accrues to } \\
\text { those who already have it. }\end{array}$ & $\begin{array}{l}\text { Decay of bridging } \\
\text { ties }\end{array}$ \\
\hline Burt (2004) & $\begin{array}{l}\text { What is the mechanism } \\
\text { by which brokerage } \\
\text { provides social capital? }\end{array}$ & Individual & $\mathrm{S}, \mathrm{B}, \mathrm{O}$ & $\begin{array}{l}\text { Empirical } \\
\text { quantitative }\end{array}$ & $\begin{array}{l}673 \text { managers who ran the } \\
\text { supply chain in } 2001 \text { for one } \\
\text { of America's largest } \\
\text { electronics companies }\end{array}$ & $\begin{array}{l}\text { Good ideas emerge from the } \\
\text { intersection of social worlds, but } \\
\text { spread in a way that would continue } \\
\text { segregation between the worlds. } \\
\text { There was a brokerage advantage in } \\
\text { producing ideas. However, the } \\
\text { potential value for integrating } \\
\text { operations across the company is } \\
\text { dissipated in the distribution of ideas. }\end{array}$ & $\begin{array}{l}\text { Performance } \\
\text { (salary, } \\
\text { evaluation, } \\
\text { promotion) and } \\
\text { good ideas (idea } \\
\text { value, idea } \\
\text { dismissed, no } \\
\text { idea, and discuss } \\
\text { idea) }\end{array}$ \\
\hline Burt (2007) & $\begin{array}{l}\text { Do the performance } \\
\text { benefits of direct } \\
\text { brokerage extend to } \\
\text { secondhand brokerage? }\end{array}$ & $\begin{array}{l}\text { Intra- } \\
\text { organization }\end{array}$ & $\mathrm{S}, \mathrm{O}$ & $\begin{array}{l}\text { Empirical } \\
\text { quantitative }\end{array}$ & $\begin{array}{l}\text { Cross-section of } 673 \\
\text { managers in a large } \\
\text { organization }\end{array}$ & $\begin{array}{l}\text { Secondhand brokerage-moving } \\
\text { information between people to whom } \\
\text { one is only connected indirectly- } \\
\text { often has little or no value. Brokerage } \\
\text { benefits are dramatically } \\
\text { concentrated in the immediate } \\
\text { network around a person. }\end{array}$ & $\begin{array}{l}\text { Salary and } \\
\text { evaluation }\end{array}$ \\
\hline Burt (2012) & $\begin{array}{l}\text { How much does network } \\
\text { advantage depend on the } \\
\text { person? }\end{array}$ & Individual & $\mathrm{A}, \mathrm{S}, \mathrm{O}$ & $\begin{array}{l}\text { Empirical } \\
\text { quantitative }\end{array}$ & $\begin{array}{l}\text { 13,968 individuals playing } \\
44,185 \text { characters from } \\
\text { EverQuest II data }\end{array}$ & $\begin{array}{l}\text { Individuals recreate the same } \\
\text { network across the roles they play, } \\
\text { but this network consistency } \\
\text { contributes almost nothing to } \\
\text { network advantage. }\end{array}$ & $\begin{array}{l}\text { The game level a } \\
\text { character achieved } \\
\text { and structural } \\
\text { holes in character } \\
\text { networks }\end{array}$ \\
\hline Burt (2015) & $\begin{array}{l}\text { What happens when } \\
\text { either or both alters in a } \\
\text { structural hole belong to } \\
\text { dense groups? }\end{array}$ & $\begin{array}{l}\text { Individual, } \\
\text { Intra- } \\
\text { organization }\end{array}$ & $\mathrm{S}, \mathrm{O}$ & $\begin{array}{l}\text { Empirical } \\
\text { quantitative }\end{array}$ & $\begin{array}{l}\text { Social network data from } \\
360 \text { investment bankers in a } \\
\text { large financial organization } \\
\text { during four successive years } \\
\text { in the mid-1990s. }\end{array}$ & $\begin{array}{l}\text { The more reinforced the hole, the } \\
\text { greater the difficulty in bridging it, } \\
\text { but the more likely a successful } \\
\text { bridge will carry information novel, } \\
\text { and so potentially valuable, to people } \\
\text { on the other side. }\end{array}$ & Compensation \\
\hline
\end{tabular}


NETWORK BROKERAGE 59

\begin{tabular}{|c|c|c|c|c|c|c|c|}
\hline Author(s) & Research question(s) & $\begin{array}{l}\text { Level(s) of } \\
\text { analysis }\end{array}$ & $\begin{array}{c}\text { Categories of } \\
\text { factors }\end{array}$ & $\begin{array}{l}\text { Type of } \\
\text { article }\end{array}$ & Sample & Findings/Conclusions & Outcomes \\
\hline $\begin{array}{l}\text { Burt, Hogarth, } \\
\& \text { Michaud } \\
(2000)\end{array}$ & $\begin{array}{l}\text { Is that network form of } \\
\text { social capital unique to } \\
\text { Americans? }\end{array}$ & Individual & $\mathrm{A}, \mathrm{S}, \mathrm{O}, \mathrm{M}$ & $\begin{array}{l}\text { Empirical } \\
\text { quantitative }\end{array}$ & $\begin{array}{l}\text { Network and performance } \\
\text { data on two study } \\
\text { populations of } 170 \text { American } \\
\text { and } 60 \text { French senior } \\
\text { managers global market } \\
\text { leaders with tens of } \\
\text { thousands of employees }\end{array}$ & $\begin{array}{l}\text { There is a competitive advantage of } \\
\text { building bridge relationship While } \\
\text { American managers have a broader } \\
\text { range of contacts and associate } \\
\text { positive emotions with their bridge } \\
\text { relationship; French managers } \\
\text { operate with a less porous social } \\
\text { boundary around their firm and } \\
\text { associate negative emotions with } \\
\text { bridge relationships. }\end{array}$ & $\begin{array}{l}\text { Compensation and } \\
\text { redundancy of } \\
\text { colleague } \\
\text { relationship }\end{array}$ \\
\hline $\begin{array}{l}\text { Carnabuci \& } \\
\text { Dioszegi } \\
(2015)\end{array}$ & $\begin{array}{l}\text { Which network structure } \\
\text { is most conducive to } \\
\text { innovative performance? }\end{array}$ & Individual & $\mathrm{S}, \mathrm{O}, \mathrm{M}$ & $\begin{array}{l}\text { Empirical } \\
\text { quantitative }\end{array}$ & $\begin{array}{l}\text { Intraorganizational networks } \\
\text { of all employees within a } \\
\text { design and manufacturing } \\
\text { company }\end{array}$ & $\begin{array}{l}\text { Whether a brokering or a closed } \\
\text { network will enhance an employee's } \\
\text { innovative performance is contingent } \\
\text { on that employee's idiosyncratic } \\
\text { cognitive style. }\end{array}$ & $\begin{array}{l}\text { Innovative } \\
\text { performance (idea } \\
\text { creation and idea } \\
\text { implementation) }\end{array}$ \\
\hline Castilla (2005) & $\begin{array}{l}\text { What is the role of } \\
\text { referral contacts on } \\
\text { workers' performance? }\end{array}$ & Individual & $\mathrm{S}, \mathrm{O}$ & $\begin{array}{l}\text { Empirical } \\
\text { quantitative }\end{array}$ & $\begin{array}{l}\text { Employees' hiring and } \\
\text { performance data in a call } \\
\text { center }\end{array}$ & $\begin{array}{l}\text { The effect of referral ties continues } \\
\text { beyond the hiring process, having } \\
\text { long-term effects on employee } \\
\text { attachment to the firm and on } \\
\text { performance. }\end{array}$ & $\begin{array}{l}\text { Employee } \\
\text { performance } \\
\text { (objective and } \\
\text { subjective) }\end{array}$ \\
\hline $\begin{array}{l}\text { Chandler, } \\
\text { Haunschild, } \\
\text { Rhee, \& } \\
\text { Beckman } \\
\text { (2013) }\end{array}$ & $\begin{array}{l}\text { How may a firm's } \\
\text { reputation and status } \\
\text { enable or constrain the } \\
\text { firm in its partner } \\
\text { selection? }\end{array}$ & $\begin{array}{l}\text { Inter- } \\
\text { organization }\end{array}$ & A, S & $\begin{array}{l}\text { Empirical } \\
\text { quantitative }\end{array}$ & $\begin{array}{l}\text { Network partners in the } \\
\text { years } 1985,1990 \text {, and } 1993 \\
\text { from the } 300 \text { largest publicly } \\
\text { held service and } \\
\text { manufacturing firms listed in } \\
\text { the United States in } 1990\end{array}$ & $\begin{array}{l}\text { High-status firms have networks that } \\
\text { are higher in partner quality but are } \\
\text { less diverse and contain fewer } \\
\text { opportunities to bridge structural } \\
\text { holes than the networks of high- } \\
\text { reputation firms. }\end{array}$ & - \\
\hline $\begin{array}{l}\text { Clement, } \\
\text { Shipilov, \& } \\
\text { Galunic } \\
\text { (2018) }\end{array}$ & $\begin{array}{l}\text { What are the positive and } \\
\text { negative externalities of } \\
\text { "hubs" who act as the } \\
\text { main interfaces between } \\
\text { members of their own } \\
\text { network community } \\
\text { ("network neighbors") } \\
\text { and members of other } \\
\text { communities? }\end{array}$ & Individual & $\mathrm{S}, \mathrm{O}, \mathrm{M}$ & $\begin{array}{l}\text { Empirical } \\
\text { mixed } \\
\text { methods }\end{array}$ & $\begin{array}{l}171 \text { French television game } \\
\text { shows from } 1995 \text { to } 2012\end{array}$ & $\begin{array}{l}\text { The positive externalities of hubs } \\
\text { help their neighbors contribute to the } \\
\text { success of projects when these } \\
\text { neighbors hold creativity-focused } \\
\text { roles; yet the negative externalities of } \\
\text { hubs hinder their neighbors' } \\
\text { contributions when they hold } \\
\text { efficiency-focused roles. }\end{array}$ & $\begin{array}{l}\text { Viewership } \\
\text { ratings of game } \\
\text { show }\end{array}$ \\
\hline
\end{tabular}


NETWORK BROKERAGE 60

\begin{tabular}{|c|c|c|c|c|c|c|c|}
\hline Author(s) & Research question(s) & $\begin{array}{l}\text { Level(s) of } \\
\text { analysis }\end{array}$ & $\begin{array}{c}\text { Categories of } \\
\text { factors }\end{array}$ & $\begin{array}{l}\text { Type of } \\
\text { article }\end{array}$ & Sample & Findings/Conclusions & Outcomes \\
\hline $\begin{array}{l}\text { Collins- } \\
\text { Dogrul (2012) }\end{array}$ & $\begin{array}{l}\text { How do organizations } \\
\text { and the professionals } \\
\text { who work for them } \\
\text { bridge international } \\
\text { divisions to cooperate on } \\
\text { transnational public } \\
\text { health issues when } \\
\text { bordering countries have } \\
\text { disparate epidemiological } \\
\text { profiles, public health } \\
\text { and medical systems } \\
\text { (normative, legal, } \\
\text { administrative), political } \\
\text { economies, and national } \\
\text { interests? }\end{array}$ & $\begin{array}{l}\text { Individual, } \\
\text { Inter- } \\
\text { organization }\end{array}$ & $\mathrm{S}, \mathrm{B}, \mathrm{O}$ & $\begin{array}{l}\text { Empirical } \\
\text { qualitative }\end{array}$ & $\begin{array}{l}\text { Case study on the public } \\
\text { health cooperation on the } \\
\text { USA-Mexico border } \\
\text { (archival data and } 22 \\
\text { interviews) }\end{array}$ & $\begin{array}{l}\text { Brokers have a role in closed } \\
\text { networks and can have an interest in } \\
\text { joining actors. iungens brokerage is a } \\
\text { sustained process that creates new } \\
\text { networks and reinforces old ones } \\
\text { against the divisive influences of } \\
\text { state institutions. }\end{array}$ & $\begin{array}{l}\text { The } \\
\text { institutionalization } \\
\text { of organizations } \\
\text { that specialize in } \\
\text { iungens brokerage }\end{array}$ \\
\hline $\begin{array}{l}\text { Cummings \& } \\
\text { Cross (2003) }\end{array}$ & $\begin{array}{l}\text { What is the link between } \\
\text { structural properties of } \\
\text { groups engaged in } \\
\text { complex, non-routine } \\
\text { work and performance? }\end{array}$ & Group & $\mathrm{S}, \mathrm{O}$ & $\begin{array}{l}\text { Empirical } \\
\text { quantitative }\end{array}$ & $\begin{array}{l}182 \text { work groups in a } \\
\text { Fortune } 500 \text { global } \\
\text { telecommunication } \\
\text { organization }\end{array}$ & $\begin{array}{l}\text { Structural holes of leaders within } \\
\text { groups as well as core-periphery and } \\
\text { hierarchical group structures were } \\
\text { negatively associated with } \\
\text { performance. }\end{array}$ & $\begin{array}{l}\text { Work group } \\
\text { performance }\end{array}$ \\
\hline $\begin{array}{l}\text { Currie \& } \\
\text { White (2012) }\end{array}$ & $\begin{array}{l}\text { How do professional } \\
\text { affiliation and associated } \\
\text { power differentials affect } \\
\text { knowledge brokering at } \\
\text { the individual and group } \\
\text { levels within an } \\
\text { organization? }\end{array}$ & $\begin{array}{l}\text { Individual, } \\
\text { Group }\end{array}$ & $\mathrm{S}, \mathrm{B}, \mathrm{O}, \mathrm{M}$ & $\begin{array}{l}\text { Empirical } \\
\text { mixed } \\
\text { methods }\end{array}$ & $\begin{array}{l}\text { Professionals and managers } \\
\text { involved in the delivery of } \\
\text { pediatric nephrology services } \\
\text { to children with a long-term } \\
\text { kidney problem }\end{array}$ & $\begin{array}{l}\text { Knowledge brokering is as much, if } \\
\text { not more, a group phenomenon, } \\
\text { rather than enacted by individuals. } \\
\text { Individual-level and collective-level } \\
\text { knowledge brokering are } \\
\text { interdependent, as each facilitates the } \\
\text { other. }\end{array}$ & Knowledge \\
\hline $\begin{array}{l}\text { Dahlander \& } \\
\text { Wallin (2006) }\end{array}$ & $\begin{array}{l}\text { How do firms try to } \\
\text { unlock communities as } \\
\text { complementary assets? }\end{array}$ & $\begin{array}{l}\text { Individual, } \\
\text { Organization }\end{array}$ & $\mathrm{S}, \mathrm{O}$ & $\begin{array}{l}\text { Empirical } \\
\text { quantitative }\end{array}$ & $\begin{array}{l}1,659 \text { individuals in the free } \\
\text { and open source software } \\
\text { industry, who sent } 14,644 \\
\text { emails in a mailing list over } \\
\text { a } 6 \text {-year period }\end{array}$ & $\begin{array}{l}\text { Individuals sponsored by firms (as } \\
\text { opposed to freelancers) interact with } \\
\text { a greater number of individuals, and } \\
\text { the number of individuals they } \\
\text { interact with is greater than the } \\
\text { number of individuals who contact } \\
\text { them. Sponsored individuals are keen } \\
\text { to establish their legitimacy in the } \\
\text { community, but other community } \\
\text { participants may be suspicious about } \\
\text { their corporate agenda. }\end{array}$ & $\begin{array}{l}\text { (1) } \\
\text { out-degree; (2) in- } \\
\text { degree; }(3) \\
\text { prestige; }(4) \\
\text { eigenvector. }\end{array}$ \\
\hline
\end{tabular}


NETWORK BROKERAGE 61

\begin{tabular}{|c|c|c|c|c|c|c|c|}
\hline Author(s) & Research question(s) & $\begin{array}{l}\text { Level(s) of } \\
\text { analysis }\end{array}$ & $\begin{array}{c}\text { Categories of } \\
\text { factors }\end{array}$ & $\begin{array}{l}\text { Type of } \\
\text { article }\end{array}$ & Sample & Findings/Conclusions & Outcomes \\
\hline Davis_(2016) & $\begin{array}{l}\text { How do organizations } \\
\text { collaborate with multiple } \\
\text { partners, such as when } \\
\text { they develop innovative } \\
\text { and complex product } \\
\text { platforms like } \\
\text { smartphones, servers, and } \\
\text { MRI machines that rely } \\
\text { on technologies } \\
\text { developed by } \\
\text { organizations in three or } \\
\text { more sectors? }\end{array}$ & Organization & $\mathrm{B}, \mathrm{O}$ & & $\begin{array}{l}8 \text { technology collaborations } \\
\text { between } 10 \text { organizations } \\
\text { lasted from } 1 \text { to } 3 \text { years } \\
\text { between } 2001 \text { and } 2006\end{array}$ & $\begin{array}{l}\text { Successful groups used a dynamic } \\
\text { collaboration process named "'group } \\
\text { cycling,'” in which managers viewed } \\
\text { their triad as a small group, } \\
\text { decomposed innovative activities into } \\
\text { a series of interlinked dyads between } \\
\text { different pairs of partners, and } \\
\text { managed third-party interests across } \\
\text { time. }\end{array}$ & $\begin{array}{l}\text { Innovation } \\
\text { performance (new } \\
\text { and useful } \\
\text { technology } \\
\text { combinations) }\end{array}$ \\
\hline $\begin{array}{l}\text { Davis \& } \\
\text { Eisenhardt } \\
(2011)\end{array}$ & $\begin{array}{l}\text { How do organizations } \\
\text { collaborate with multiple } \\
\text { partners that rely on } \\
\text { technologies developed } \\
\text { by organizations in three } \\
\text { or more sectors? }\end{array}$ & Organization & $\mathrm{B}, \mathrm{O}, \mathrm{M}$ & $\begin{array}{l}\text { Empirical } \\
\text { qualitative }\end{array}$ & $\begin{array}{l}6 \text { groups, each composed of } \\
3 \text { organizations engaged in } \\
\text { technology and product } \\
\text { development in the computer } \\
\text { industry }\end{array}$ & $\begin{array}{l}\text { Isolation and linking are } \\
\text { complementary mechanisms used to } \\
\text { generate a lengthy cycle of dyads that } \\
\text { makes effective use of third-party } \\
\text { contributions. }\end{array}$ & $\begin{array}{l}\text { Innovation } \\
\text { performance (new } \\
\text { and useful } \\
\text { technology } \\
\text { combinations) }\end{array}$ \\
\hline $\begin{array}{l}\text { de Vaan, } \\
\text { Stark, \& } \\
\text { Vedres }(2015)\end{array}$ & $\begin{array}{l}\text { Why are some creative } \\
\text { teams able to produce } \\
\text { game changers-cultural } \\
\text { products that stand out as } \\
\text { distinctive while also } \\
\text { being critically } \\
\text { recognized as } \\
\text { outstanding? }\end{array}$ & Organization & $\mathrm{S}, \mathrm{B}, \mathrm{O}, \mathrm{M}$ & $\begin{array}{l}\text { Empirical } \\
\text { qualitative }\end{array}$ & $\begin{array}{l}\text { Team reassembly for } 12,422 \\
\text { video games and the career } \\
\text { histories of } 139,727 \text { video } \\
\text { game developers }\end{array}$ & $\begin{array}{l}\text { When combined with cognitive } \\
\text { distance, structural folding channels } \\
\text { and mobilizes a productive tension of } \\
\text { rules, roles, and codes that promotes } \\
\text { successful innovation. }\end{array}$ & $\begin{array}{l}\text { Innovation } \\
\text { (distinctiveness, } \\
\text { critical acclaim, } \\
\text { and game } \\
\text { changer) }\end{array}$ \\
\hline Ebbers (2014) & $\begin{array}{l}\text { What is the relationship } \\
\text { between networking } \\
\text { behavior of entrepreneurs } \\
\text { and the number of } \\
\text { contractual ties with } \\
\text { other entrepreneurs? }\end{array}$ & Individual & $\mathrm{A}, \mathrm{B}, \mathrm{O}$ & $\begin{array}{l}\text { Empirical } \\
\text { quantitative }\end{array}$ & $\begin{array}{l}\text { Survey with } 101 \text { respondents } \\
\text { from entrepreneurs } \\
\text { collaborating with four } \\
\text { incubators in the city of } \\
\text { Amsterdam held in } 2010\end{array}$ & $\begin{array}{l}\text { Both types of networking behavior } \\
\text { are positively related with the } \\
\text { number of business partners to whom } \\
\text { entrepreneurs give business } \\
\text { assignments. However, no } \\
\text { relationship between networking } \\
\text { behavior and the number of business } \\
\text { partners from whom entrepreneurs } \\
\text { receive business assignments. }\end{array}$ & $\begin{array}{l}\text { Internal } \\
\text { contracting } \\
\text { relationships of } \\
\text { firms within } \\
\text { incubators } \\
\text { (inward and } \\
\text { outward } \\
\text { contracting } \\
\text { partners) }\end{array}$ \\
\hline
\end{tabular}


NETWORK BROKERAGE 62

\begin{tabular}{|c|c|c|c|c|c|c|c|}
\hline Author(s) & Research question(s) & $\begin{array}{l}\text { Level(s) of } \\
\text { analysis }\end{array}$ & $\begin{array}{c}\text { Categories of } \\
\text { factors } 4\end{array}$ & $\begin{array}{l}\text { Type of } \\
\text { article }\end{array}$ & Sample & Findings/Conclusions & Outcomes \\
\hline $\begin{array}{l}\text { Fang, Chi, } \\
\text { Chen, \& } \\
\text { Baron (2015) }\end{array}$ & $\begin{array}{l}\text { (1) Why are some } \\
\text { entrepreneurs better than } \\
\text { others at developing } \\
\text { resource-rich networks } \\
\text { that provide them access } \\
\text { to social capital critical } \\
\text { for venture performance? } \\
\text { Do individual } \\
\text { characteristics influence } \\
\text { network construction? } \\
\text { (2) Given the same level } \\
\text { of accessible social } \\
\text { capital, why do some } \\
\text { entrepreneurs mobilize } \\
\text { social capital better than } \\
\text { others to achieve } \\
\text { desirable venture } \\
\text { performance? Do } \\
\text { individual characteristics } \\
\text { affect the use of } \\
\text { networks? }\end{array}$ & Individual & $\mathrm{A}, \mathrm{S}, \mathrm{O}, \mathrm{M}$ & $\begin{array}{l}\text { Empirical } \\
\text { qualitative }\end{array}$ & $\begin{array}{l}\text { Interviews and surveys of } 28 \\
\text { entrepreneurs in } 10 \\
\text { industries during a six-month } \\
\text { period }\end{array}$ & $\begin{array}{l}\text { Entrepreneurs differ considerably in } \\
\text { their political skill for building } \\
\text { effective social networks and } \\
\text { extracting resources once they exist. }\end{array}$ & Social capital \\
\hline $\begin{array}{l}\text { Fernandez \& } \\
\text { Gould (1994) }\end{array}$ & $\begin{array}{l}\text { How do the occupancy of } \\
\text { brokerage positions and } \\
\text { policy-event participation } \\
\text { interact as determinants } \\
\text { of influence reputation? }\end{array}$ & Organization & $\mathrm{S}, \mathrm{O}, \mathrm{M}$ & $\begin{array}{l}\text { Empirical } \\
\text { quantitative }\end{array}$ & $\begin{array}{l}\text { Communication network in } \\
\text { the national energy and } \\
\text { health policy domains under } \\
\text { the Carter presidency } \\
\text { collected by Laumann and } \\
\text { Knoke }\end{array}$ & $\begin{array}{l}\text { The ability to convert structural } \\
\text { position into power is contingent on } \\
\text { the type of brokerage position } \\
\text { occupied and whether the actor is a } \\
\text { government organization. In the } \\
\text { government sector, actors in } \\
\text { representative positions are more } \\
\text { influential to the extent that they take } \\
\text { public stands on events, whereas } \\
\text { liaison and itinerant positions only } \\
\text { confer influence if their occupants } \\
\text { remain impartial. }\end{array}$ & $\begin{array}{l}\text { Influence } \\
\text { reputation }\end{array}$ \\
\hline $\begin{array}{l}\text { Fernandez- } \\
\text { Mateo (2007) }\end{array}$ & $\begin{array}{l}\text { How does a broker's } \\
\text { ability to affect prices } \\
\text { and extract superior } \\
\text { value from its position } \\
\text { influence economic } \\
\text { consequences for the } \\
\text { actors tied to it? }\end{array}$ & Individual & $\mathrm{B}, \mathrm{O}$ & $\begin{array}{l}\text { Empirical } \\
\text { mixed } \\
\text { methods }\end{array}$ & $\begin{array}{l}\text { Global staffing agency s } \\
\text { proprietary information on } \\
\text { contractors' job histories and } \\
\text { client data as well as } 15 \\
\text { months of fieldwork }\end{array}$ & $\begin{array}{l}\text { The broker is able to transfer } \\
\text { discounts offered to valued buyers } \\
\text { (clients) on to the sellers (workers) } \\
\text { matched with them, instead of } \\
\text { reducing its own margins. As a } \\
\text { result, actors with the same resource } \\
\text { endowments receive different prices } \\
\text { depending on the relationships } \\
\text { among other exchange partners in a } \\
\text { given triadic network of ties. }\end{array}$ & $\begin{array}{l}\text { The hourly bill } \\
\text { rates that clients } \\
\text { (buyers) pay to } \\
\text { InterCo for a } \\
\text { given project and } \\
\text { the hourly pay } \\
\text { rates that workers } \\
\text { (sellers) receive } \\
\text { from InterCo. }\end{array}$ \\
\hline
\end{tabular}


NETWORK BROKERAGE 63

\begin{tabular}{|c|c|c|c|c|c|c|c|}
\hline Author(s) & Research question(s) & $\begin{array}{l}\text { Level(s) of } \\
\text { analysis }\end{array}$ & $\begin{array}{c}\text { Categories of } \\
\text { factors }\end{array}$ & $\begin{array}{l}\text { Type of } \\
\text { article }\end{array}$ & Sample & Findings/Conclusions & Outcomes \\
\hline $\begin{array}{l}\text { Fernandez, } \\
\text { Castilla, \& } \\
\text { Moore }(2000)\end{array}$ & $\begin{array}{l}\text { What are the social } \\
\text { mechanisms at work in } \\
\text { hiring via referrals? }\end{array}$ & $\begin{array}{l}\text { Individual, } \\
\text { Organization }\end{array}$ & $\mathrm{B}, \mathrm{O}$ & $\begin{array}{l}\text { Empirical } \\
\text { quantitative }\end{array}$ & $\begin{array}{l}4,100 \text { applicants for entry- } \\
\text { level positions at a telephone } \\
\text { customer service center of a } \\
\text { large bank }\end{array}$ & $\begin{array}{l}\text { The firm's investment in the social } \\
\text { capital of its employees yields } \\
\text { significant economic returns through } \\
\text { getting a "richer" applicant pool, } \\
\text { having a "better" match between } \\
\text { applicants and jobs, and providing an } \\
\text { "enriched" work environment to the } \\
\text { applicants. }\end{array}$ & $\begin{array}{l}\text { Economic returns } \\
\text { in terms of } \\
\text { screening, hiring, } \\
\text { and training new } \\
\text { employees }\end{array}$ \\
\hline $\begin{array}{l}\text { Fleming \& } \\
\text { Waguespack } \\
(2007)\end{array}$ & $\begin{array}{l}\text { What types of human and } \\
\text { social capital identify the } \\
\text { emergence of leaders of } \\
\text { open innovation } \\
\text { communities? }\end{array}$ & Individual & $\mathrm{S}, \mathrm{B}, \mathrm{O}, \mathrm{M}$ & $\begin{array}{l}\text { Empirical } \\
\text { quantitative }\end{array}$ & $\begin{array}{l}\text { Careers within the Internet } \\
\text { Engineering Task Force } \\
\text { community, 1986-2002 }\end{array}$ & $\begin{array}{l}\text { An inherent lack of trust associated } \\
\text { with brokerage positions can be } \\
\text { overcome through physical } \\
\text { interaction. Boundary spanners do } \\
\text { not suffer this handicap and are much } \\
\text { more likely than brokers to advance } \\
\text { to leadership. }\end{array}$ & $\begin{array}{l}\text { Likelihood of } \\
\text { becoming an open } \\
\text { innovation } \\
\text { community leader }\end{array}$ \\
\hline $\begin{array}{l}\text { Fleming, } \\
\text { Mingo, \& } \\
\text { Chen }(2007)\end{array}$ & $\begin{array}{l}\text { How does brokerage } \\
\text { work? }\end{array}$ & Individual & $\mathrm{S}, \mathrm{O}, \mathrm{M}$ & $\begin{array}{l}\text { Empirical } \\
\text { quantitative }\end{array}$ & $\begin{array}{l}\text { U.S. utility patents granted, } \\
1975-2002\end{array}$ & $\begin{array}{l}\text { Brokerage can aid in the generation } \\
\text { of an idea but then hamper its } \\
\text { diffusion and use by others. }\end{array}$ & $\begin{array}{l}\text { New } \\
\text { combinations (the } \\
\text { \# of new subclass } \\
\text { pairs within each } \\
\text { of a focal } \\
\text { inventor's patents) } \\
\text { and uses of the } \\
\text { combinations } \\
\text { (how many times } \\
\text { other inventors } \\
\text { used the investor's } \\
\text { new } \\
\text { combinations) }\end{array}$ \\
\hline $\begin{array}{l}\text { Floyd \& } \\
\text { Wooldridge } \\
(1997)\end{array}$ & $\begin{array}{l}\text { (1) How is middle } \\
\text { management's strategic } \\
\text { influence activity related } \\
\text { to improved } \\
\text { organizational } \\
\text { performance? (2) What } \\
\text { makes some middle } \\
\text { managers engage in more } \\
\text { of such activity than } \\
\text { others? }\end{array}$ & $\begin{array}{l}\text { Individual, } \\
\text { Organization }\end{array}$ & $\mathrm{B}, \mathrm{O}, \mathrm{M}$ & $\begin{array}{l}\text { Empirical } \\
\text { quantitative }\end{array}$ & $\begin{array}{l}259 \text { middle managers with } \\
\text { formal position in boundary- } \\
\text { spanning sub-units from } 25 \\
\text { organizations representing a } \\
\text { wide variety of industries }\end{array}$ & $\begin{array}{l}\text { Middle managers' strategic influence } \\
\text { arises from their ability to mediate } \\
\text { between internal and external } \\
\text { selection environments. In addition, } \\
\text { positive effects on organizational } \\
\text { performance appear to depend on: (1) } \\
\text { whether the overall pattern of upward } \\
\text { influence is conducive to shifts in the } \\
\text { network centrality of individual } \\
\text { managers; and (2) whether the } \\
\text { pattern of downward influence is } \\
\text { consistent with an appropriate } \\
\text { balance between the organization's } \\
\text { need for control and flexibility. }\end{array}$ & $\begin{array}{l}\text { Middle } \\
\text { management } \\
\text { strategic influence }\end{array}$ \\
\hline
\end{tabular}


NETWORK BROKERAGE 64

\begin{tabular}{|c|c|c|c|c|c|c|c|}
\hline Author(s) & Research question(s) & $\begin{array}{l}\text { Level(s) of } \\
\text { analysis }\end{array}$ & $\begin{array}{c}\text { Categories of } \\
\text { factors }\end{array}$ & $\begin{array}{l}\text { Type of } \\
\text { article }\end{array}$ & Sample & Findings/Conclusions & Outcomes \\
\hline $\begin{array}{l}\text { Flynn \& } \\
\text { Wiltermuth } \\
(2010)\end{array}$ & $\begin{array}{l}\text { Do brokers in a social } \\
\text { network show evidence } \\
\text { of false consensus in } \\
\text { ethical decision making? }\end{array}$ & Individual & $\mathrm{S}, \mathrm{O}$ & $\begin{array}{l}\text { Empirical } \\
\text { quantitative }\end{array}$ & $\begin{array}{l}\text { MBA students, students } \\
\text { enrolled in a Master of } \\
\text { Management program for } \\
\text { executives, and employees in } \\
\text { the marketing department of } \\
\text { a manufacturing firm }\end{array}$ & $\begin{array}{l}\text { The tendency to avoid moral } \\
\text { discourse and instead discuss } \\
\text { superficial connections worsens the } \\
\text { false consensus bias in ethical } \\
\text { decision making, providing an } \\
\text { illusion of consensus where none } \\
\text { exists. }\end{array}$ & $\begin{array}{l}\text { Social support for } \\
\text { views on ethical } \\
\text { issues }\end{array}$ \\
\hline $\begin{array}{l}\text { Friedman \& } \\
\text { Podolny } \\
(1992)\end{array}$ & $\begin{array}{l}\text { What are the structural } \\
\text { conditions that are the } \\
\text { basis of the role conflict } \\
\text { experienced by boundary } \\
\text { spanning? }\end{array}$ & Individual & S, D & $\begin{array}{l}\text { Empirical } \\
\text { quantitative }\end{array}$ & $\begin{array}{l}\text { Longitudinal observation of } \\
\text { one labor negotiation } \\
\text { situation }\end{array}$ & $\begin{array}{l}\text { The boundary function is composed } \\
\text { of multiple types of relations and two } \\
\text { independent roles. }\end{array}$ & - \\
\hline $\begin{array}{l}\text { Galunic, } \\
\text { Ertug, \& } \\
\text { Gargiulo } \\
(2012)\end{array}$ & $\begin{array}{l}\text { Does a second-order } \\
\text { social capital matter to } \\
\text { the ability of a focal actor } \\
\text { to add value to those } \\
\text { around him/her? }\end{array}$ & Individual & $\mathrm{S}, \mathrm{O}$ & $\begin{array}{l}\text { Empirical } \\
\text { quantitative }\end{array}$ & $\begin{array}{l}\text { Value added ratings for some } \\
2,200 \text { bankers working in a } \\
\text { global investment bank }\end{array}$ & $\begin{array}{l}\text { Second-order social capital does } \\
\text { matter, when contacts are senior } \\
\text { brokers. }\end{array}$ & $\begin{array}{l}\text { The average rating } \\
\text { received by an } \\
\text { employee from all } \\
\text { those who rated } \\
\text { her/him in a given } \\
\text { year }\end{array}$ \\
\hline $\begin{array}{l}\text { Gargiulo \& } \\
\text { Benassi (2000) }\end{array}$ & $\begin{array}{l}\text { How does the structure of } \\
\text { an actor's network affect } \\
\text { his or her ability to adapt } \\
\text { the composition of his } \\
\text { network in response to a } \\
\text { significant change in the } \\
\text { task interdependencies } \\
\text { that define that actor's } \\
\text { role? }\end{array}$ & Individual & $\mathrm{S}, \mathrm{O}$ & $\begin{array}{l}\text { Empirical } \\
\text { quantitative }\end{array}$ & $\begin{array}{l}19 \text { managers of a newly } \\
\text { created special unit } \\
\text { responsible for implementing } \\
\text { a large-scale organizational } \\
\text { change process in the Italian } \\
\text { subsidiary of a U.S. high- } \\
\text { technology firm }\end{array}$ & $\begin{array}{l}\text { There is a trade-off between the } \\
\text { safety of cooperation within cohesive } \\
\text { networks versus the flexibility } \\
\text { provided by networks rich in } \\
\text { structural holes. }\end{array}$ & $\begin{array}{l}\text { Coordination } \\
\text { failures }\end{array}$ \\
\hline $\begin{array}{l}\text { Gargiulo, } \\
\text { Ertug, \& } \\
\text { Galunic } \\
(2009)\end{array}$ & $\begin{array}{l}\text { How do the controlling } \\
\text { properties of network } \\
\text { closure on individual } \\
\text { performance vary with } \\
\text { the role a focal actor } \\
\text { plays toward his or her } \\
\text { contacts? }\end{array}$ & Individual & $\mathrm{S}, \mathrm{O}, \mathrm{M}$ & $\begin{array}{l}\text { Empirical } \\
\text { quantitative }\end{array}$ & $\begin{array}{l}\text { Data on informal exchanges } \\
\text { among investment bankers in } \\
\text { the equities division of a } \\
\text { large financial services fi rm } \\
\text { operating in Europe, Asia- } \\
\text { Pacific, Africa, and the } \\
\text { Americas in } 2001\end{array}$ & $\begin{array}{l}\text { Network closure in relationships in } \\
\text { which the banker acts as an acquirer } \\
\text { of information increases his or her } \\
\text { performance, whereas closure in } \\
\text { relationships in which the banker acts } \\
\text { as a provider of information } \\
\text { decreases it. }\end{array}$ & $\begin{array}{l}\text { The annual bonus } \\
\text { received by the } \\
\text { banker for } \\
\text { performance in } \\
\text { the } 2001 \text { calendar } \\
\text { year. }\end{array}$ \\
\hline $\begin{array}{l}\text { Giudici, } \\
\text { Reinmoeller, } \\
\text { \& Ravasi } \\
(2018)\end{array}$ & $\begin{array}{l}\text { What are the processes } \\
\text { through which open- } \\
\text { system orchestrators } \\
\text { encourage collaboration } \\
\text { within the network to } \\
\text { support members' search } \\
\text { and pursuit of their own } \\
\text { business opportunities? }\end{array}$ & Organization & $\mathrm{B}, \mathrm{O}$ & $\begin{array}{l}\text { Empirical } \\
\text { qualitative }\end{array}$ & $\begin{array}{l}\text { Qualitative data from a } \\
\text { major year-round business } \\
\text { matchmaking initiative } \\
\text { organized by the SME } \\
\text { association, Working } \\
\text { Together }\end{array}$ & $\begin{array}{l}\text { Dynamic capabilities might not } \\
\text { reside exclusively inside firms, but } \\
\text { could be co-created relationally with } \\
\text { other parties in the business } \\
\text { ecosystem. }\end{array}$ & $\begin{array}{l}\text { Member's } \\
\text { innovation output }\end{array}$ \\
\hline
\end{tabular}


NETWORK BROKERAGE 65

\begin{tabular}{|c|c|c|c|c|c|c|c|}
\hline Author(s) & Research question(s) & $\begin{array}{l}\text { Level(s) of } \\
\text { analysis }\end{array}$ & $\begin{array}{c}\text { Categories of } \\
\text { factors }\end{array}$ & $\begin{array}{l}\text { Type of } \\
\text { article }\end{array}$ & Sample & Findings/Conclusions & Outcomes \\
\hline $\begin{array}{l}\text { Goldberg, } \\
\text { Srivastava, } \\
\text { Manian, } \\
\text { Monroe, \& } \\
\text { Potts (2016) }\end{array}$ & $\begin{array}{l}\text { Is it better to fit in with } \\
\text { or stand out from others? }\end{array}$ & Individual & $\mathrm{S}, \mathrm{O}, \mathrm{M}$ & $\begin{array}{l}\text { Empirical } \\
\text { quantitative }\end{array}$ & $\begin{array}{l}\text { Personnel records as well as } \\
\text { a corpus of } 10.24 \text { million e- } \\
\text { mails exchanged over a } \\
\text { period of more than five } \\
\text { years among } 601 \text { employees } \\
\text { in a U.S.-based technology } \\
\text { firm }\end{array}$ & $\begin{array}{l}\text { Career benefits accrue to people who } \\
\text { are embedded in one of structural or } \\
\text { cultural dimensions and disembedded } \\
\text { in the other. In other words, the } \\
\text { informational returns to spanning } \\
\text { structural holes are greater for people } \\
\text { who fit culturally with their } \\
\text { colleagues in an organization, } \\
\text { whereas individuals who are } \\
\text { structurally embedded-that is, have } \\
\text { high levels of network constraint- } \\
\text { can enjoy the benefits of cultural } \\
\text { distinctiveness. }\end{array}$ & $\begin{array}{l}\text { The hazard of } \\
\text { experiencing } \\
\text { involuntary exit } \\
\text { from the firm (i.e., } \\
\text { negative } \\
\text { attainment) and } \\
\text { the likelihood of } \\
\text { receiving a } \\
\text { favorable } \\
\text { performance } \\
\text { rating (i.e., } \\
\text { positive } \\
\text { attainment) }\end{array}$ \\
\hline $\begin{array}{l}\text { Grosser, } \\
\text { Obstfeld, } \\
\text { Choi, } \\
\text { Woehler, } \\
\text { Lopez- } \\
\text { Kidwell, } \\
\text { Labianca, \& } \\
\text { Borgatti } \\
\text { (2018) }\end{array}$ & $\begin{array}{l}\text { How do individual } \\
\text { political skills influence } \\
\text { employee involvement } \\
\text { and performance in } \\
\text { innovation? How does } \\
\text { the presence of structural } \\
\text { hole influence this } \\
\text { influence? }\end{array}$ & $\begin{array}{l}\text { Individual, } \\
\text { Organization }\end{array}$ & $\mathrm{S}, \mathrm{B}, \mathrm{O}, \mathrm{M}$ & $\begin{array}{l}\text { Empirical } \\
\text { mixed } \\
\text { methods }\end{array}$ & $\begin{array}{l}\text { Study 1: Interviews to } 22 \\
\text { division managers and sector } \\
\text { division engineers of large } \\
\text { semiconductor manufacturer } \\
\text { headquartered in the United } \\
\text { States. Survey to } 113 \\
\text { employees working within } \\
\text { one division. Study 2: } \\
\text { Replication study including } \\
\text { interviews and survey to } 33 \\
\text { cardiac physicians and } \\
\text { surgeons in a cardiovascular } \\
\text { institute on the main campus } \\
\text { of a large hospital system } \\
\text { located in the Midwestern } \\
\text { United States. }\end{array}$ & $\begin{array}{l}\text { Networks rich in structural holes } \\
\text { provide opportunities that politically } \\
\text { skilled employees are uniquely } \\
\text { equipped to realize. The extent to } \\
\text { which employees span structural } \\
\text { holes in the ideation network } \\
\text { strengthens the relationship between } \\
\text { employee political skill and } \\
\text { innovation involvement. }\end{array}$ & $\begin{array}{l}\text { Employee } \\
\text { performance }\end{array}$ \\
\hline
\end{tabular}


NETWORK BROKERAGE 66

\begin{tabular}{|c|c|c|c|c|c|c|c|}
\hline Author(s) & Research question(s) & $\begin{array}{l}\text { Level(s) of } \\
\text { analysis }\end{array}$ & $\begin{array}{c}\text { Categories of } \\
\text { factors }\end{array}$ & $\begin{array}{l}\text { Type of } \\
\text { article }\end{array}$ & Sample & Findings/Conclusions & Outcomes \\
\hline $\begin{array}{l}\text { Guan \& Liu } \\
\text { (2016) }\end{array}$ & $\begin{array}{l}\text { Why and how do the } \\
\text { relational and structural } \\
\text { properties of both social } \\
\text { and knowledge networks } \\
\text { facilitate and constrain } \\
\text { exploitative and } \\
\text { explorative innovations } \\
\text { of organizations? }\end{array}$ & $\begin{array}{l}\text { Inter- } \\
\text { organization }\end{array}$ & $\mathrm{S}, \mathrm{O}$ & $\begin{array}{l}\text { Empirical } \\
\text { quantitative }\end{array}$ & $\begin{array}{l}\text { Derwent Innovation Index } \\
\text { (DII) database, Nano-energy } \\
\text { patent data, 1991-2013 }\end{array}$ & $\begin{array}{l}\text { Indirect ties of an organization's } \\
\text { knowledge elements in a knowledge } \\
\text { network affect its exploitative } \\
\text { innovation, but not its exploratory } \\
\text { innovation. However, indirect ties in } \\
\text { a collaboration network affect } \\
\text { exploratory innovation, but not } \\
\text { exploitative innovation. Non- } \\
\text { redundancy among ties in a } \\
\text { knowledge network hinders } \\
\text { exploitative innovation but favors } \\
\text { exploratory innovation. Conversely, } \\
\text { non-redundancy among ties in a } \\
\text { collaboration network favors } \\
\text { exploitative innovation but shows a } \\
\text { non-significant effect on exploratory } \\
\text { innovation. }\end{array}$ & $\begin{array}{l}\text { Exploitative and } \\
\text { exploratory } \\
\text { innovation } \\
\text { performance of a } \\
\text { focal organization }\end{array}$ \\
\hline $\begin{array}{l}\text { Guan, Zhang, } \\
\& \text { Yan (2015) }\end{array}$ & $\begin{array}{l}\text { (1) Does the structure of } \\
\text { inter-country network } \\
\text { influence collaborations } \\
\text { among cities in inter-city } \\
\text { network? (2) If so, what } \\
\text { network structure of } \\
\text { inter-country will } \\
\text { enhance a city's } \\
\text { innovation? }\end{array}$ & $\begin{array}{l}\text { City, } \\
\text { Country }\end{array}$ & $\mathrm{S}, \mathrm{O}, \mathrm{M}$ & $\begin{array}{l}\text { Empirical } \\
\text { quantitative }\end{array}$ & $\begin{array}{l}1,007 \text { U.S. patents in the } \\
\text { field of alternative energy }\end{array}$ & $\begin{array}{l}\text { Inter-country collaboration network } \\
\text { structure moderates the relationships } \\
\text { between inter-city collaboration } \\
\text { network structure and innovation } \\
\text { performance. When country's } \\
\text { centrality and structural holes are } \\
\text { high, the positive effects of city's } \\
\text { centrality and structural holes on } \\
\text { innovation performance are } \\
\text { enhanced, and the negative effects of } \\
\text { city's clustering coefficient are } \\
\text { weakened. }\end{array}$ & $\begin{array}{l}\text { Number of } \\
\text { alternative energy } \\
\text { patents }\end{array}$ \\
\hline $\begin{array}{l}\text { Gulati, Sytch, } \\
\& \\
\text { Tatarynowicz } \\
(2012)\end{array}$ & $\begin{array}{l}\text { What are the } \\
\text { evolutionary dynamics } \\
\text { underlying the } \\
\text { development and } \\
\text { transformation of small- } \\
\text { world systems? }\end{array}$ & $\begin{array}{l}\text { Inter- } \\
\text { organization }\end{array}$ & S, O, D & $\begin{array}{l}\text { Empirical } \\
\text { quantitative }\end{array}$ & $\begin{array}{l}\text { Interorganizational tie } \\
\text { formation in the global } \\
\text { computer industry, 1996- } \\
2005\end{array}$ & $\begin{array}{l}\text { The evolving social structure turns } \\
\text { from enabling the formation of } \\
\text { bridging ties to becoming a source of } \\
\text { constraint with respect to it. }\end{array}$ & $\begin{array}{l}\text { Bridging ties, } \\
\text { local ties, path } \\
\text { length, clustering } \\
\text { coefficient }\end{array}$ \\
\hline $\begin{array}{l}\text { Guler \& } \\
\text { Guillen (2010) }\end{array}$ & $\begin{array}{l}\text { What are the impacts of } \\
\text { firm specific advantages } \\
\text { arising from firms' } \\
\text { network positions in the } \\
\text { home countries? }\end{array}$ & Organization & $\mathrm{S}, \mathrm{O}, \mathrm{M}$ & $\begin{array}{l}\text { Empirical } \\
\text { quantitative }\end{array}$ & $\begin{array}{l}\text { Data on the foreign market } \\
\text { entry decisions of U.S. } \\
\text { venture capital firms } \\
\text { between } 1991 \text { and } 2002\end{array}$ & $\begin{array}{l}\text { A social status advantage is } \\
\text { transferable from one market to } \\
\text { another as a signal of quality but that } \\
\text { a brokerage advantage is more } \\
\text { context-specific and difficult to } \\
\text { transfer. Brokerage reduces foreign } \\
\text { entry in the absence of home country } \\
\text { partners in a new market and } \\
\text { increases it when partners are already } \\
\text { operating in that market. }\end{array}$ & $\begin{array}{l}\text { Rate of foreign } \\
\text { market entry }\end{array}$ \\
\hline
\end{tabular}


NETWORK BROKERAGE 67

\begin{tabular}{|c|c|c|c|c|c|c|c|}
\hline Author(s) & Research question(s) & $\begin{array}{l}\text { Level(s) of } \\
\text { analysis }\end{array}$ & $\begin{array}{c}\text { Categories of } \\
\text { factors }\end{array}$ & $\begin{array}{l}\text { Type of } \\
\text { article }\end{array}$ & Sample & Findings/Conclusions & Outcomes \\
\hline $\begin{array}{l}\text { Hahl, } \\
\text { Kacperczyk, } \\
\text { \& Davis } \\
(2016)\end{array}$ & $\begin{array}{l}\text { How is the occupancy of } \\
\text { brokerage positions } \\
\text { related to an individual's } \\
\text { knowledge of the } \\
\text { network of interactions? }\end{array}$ & $\begin{array}{l}\text { Individual, } \\
\text { Inter- } \\
\text { organization }\end{array}$ & $\mathrm{A}, \mathrm{S}, \mathrm{O}, \mathrm{M}, \mathrm{D}$ & $\begin{array}{l}\text { Empirical } \\
\text { quantitative }\end{array}$ & $\begin{array}{l}\text { Network data from a high- } \\
\text { tech organization }\end{array}$ & $\begin{array}{l}\text { Structural holes are more likely to } \\
\text { exist (and brokers more likely to } \\
\text { benefit from their position) under the } \\
\text { condition of knowledge } \\
\text { asymmetry - that is, when a broker } \\
\text { knows about a missing connection } \\
\text { between alters, but the alters lack } \\
\text { knowledge of the other alter's } \\
\text { relationship with the broker. This } \\
\text { difference in knowledge might } \\
\text { accumulate because of the positions } \\
\text { the individuals hold or because } \\
\text { individuals with differential } \\
\text { knowledge might self-sort into those } \\
\text { positions. }\end{array}$ & $\begin{array}{l}\text { Knowledge of the } \\
\text { structural hole and } \\
\text { broker } \\
\text { performance }\end{array}$ \\
\hline $\begin{array}{l}\text { Hargadon } \\
(2002)\end{array}$ & $\begin{array}{l}\text { How do organizations } \\
\text { routinely innovate by } \\
\text { recombining their past } \\
\text { knowledge in new ways? }\end{array}$ & $\begin{array}{l}\text { Individual, } \\
\text { Organization }\end{array}$ & $\mathrm{S}, \mathrm{B}, \mathrm{O}, \mathrm{M}$ & Conceptual & - & $\begin{array}{l}\text { Roles and identities may be a strong } \\
\text { influence on the abilities of } \\
\text { individuals and organizations to } \\
\text { convert their past knowledge into } \\
\text { new innovations. Network } \\
\text { perspectives run the risk of } \\
\text { presenting as static an innovation } \\
\text { process that commands attention for } \\
\text { its dynamism. Large multidivisional } \\
\text { firms may be better able to exploit } \\
\text { their broad range of diverse activities } \\
\text { by establishing internal brokering } \\
\text { units whose central task is to } \\
\text { recognize and recombine useful } \\
\text { ideas. Smaller firms may model } \\
\text { themselves after knowledge } \\
\text { brokering firms. }\end{array}$ & - \\
\hline $\begin{array}{l}\text { Hargadon \& } \\
\text { Sutton (1997) }\end{array}$ & $\begin{array}{l}\text { How does an } \\
\text { organization develop } \\
\text { innovative products } \\
\text { through technology } \\
\text { brokering? }\end{array}$ & $\begin{array}{l}\text { Inter- } \\
\text { organization }\end{array}$ & $\mathrm{A}, \mathrm{S}, \mathrm{B}, \mathrm{O}, \mathrm{M}$ & $\begin{array}{l}\text { Empirical } \\
\text { qualitative }\end{array}$ & $\begin{array}{l}\text { Engineers and managers at } \\
\text { IDEO, the largest product } \\
\text { design consulting firm in the } \\
\text { U.S. }\end{array}$ & $\begin{array}{l}\text { A technology broker firm exploits its } \\
\text { network position to gain knowledge } \\
\text { of existing technological solutions in } \\
\text { various industries and then } \\
\text { introduces these solutions where they } \\
\text { are not known and, in the process, } \\
\text { creates new products that are original } \\
\text { combinations of existing knowledge } \\
\text { from disparate industries. }\end{array}$ & $\begin{array}{l}\text { Innovation } \\
\text { (design solutions } \\
\text { that are new } \\
\text { combinations of } \\
\text { existing ideas) }\end{array}$ \\
\hline
\end{tabular}


NETWORK BROKERAGE 68

\begin{tabular}{|c|c|c|c|c|c|c|c|}
\hline Author(s) & Research question(s) & $\begin{array}{l}\text { Level(s) of } \\
\text { analysis }\end{array}$ & $\begin{array}{c}\text { Categories of } \\
\text { factors }\end{array}$ & $\begin{array}{c}\text { Type of } \\
\text { article }\end{array}$ & Sample & Findings/Conclusions & Outcomes \\
\hline $\begin{array}{l}\text { Hite \& } \\
\text { Hesterly } \\
(2001)\end{array}$ & $\begin{array}{l}\text { Are sparse networks rich } \\
\text { in structural holes more } \\
\text { conducive to the success } \\
\text { of new firms? }\end{array}$ & Organization & $\mathrm{A}, \mathrm{S}, \mathrm{O}, \mathrm{D}$ & Conceptual & - & $\begin{array}{l}\text { The shift from identity-based to more } \\
\text { calculative networks is manifested in } \\
\text { the evolution of the firm networks: } \\
\text { (1) from primarily socially embedded } \\
\text { ties to a balance of embedded and } \\
\text { arm's-length relations; (2) from } \\
\text { networks that emphasize cohesion to } \\
\text { those that exploit structural holes; } \\
\text { and (3) from a more path-dependent } \\
\text { to a more intentionally managed } \\
\text { network. }\end{array}$ & - \\
\hline $\begin{array}{l}\text { Ingram \& } \\
\text { Roberts (2000) }\end{array}$ & $\begin{array}{l}\text { Are there benefits } \\
\text { associated with } \\
\text { friendships among } \\
\text { managers of competing } \\
\text { organizations? }\end{array}$ & $\begin{array}{l}\text { Individual, } \\
\text { Organization }\end{array}$ & A, S, O & $\begin{array}{l}\text { Empirical } \\
\text { quantitative }\end{array}$ & $\begin{array}{l}\text { General managers of } 40 \\
\text { Sydney hotels }\end{array}$ & $\begin{array}{l}\text { Hotels perform better if their } \\
\text { managers have friendships with } \\
\text { competitors and if those competitors } \\
\text { are themselves friends. Also, } \\
\text { friendships are more likely between } \\
\text { managers whose hotels are close } \\
\text { competitors. Existing friendships are } \\
\text { more likely to persist, and new } \\
\text { friendships are more likely to form, if } \\
\text { the other individual manages a } \\
\text { competing hotel. }\end{array}$ & $\begin{array}{l}\text { Performance } \\
\text { (revenue per } \\
\text { available room) }\end{array}$ \\
\hline Jensen (2008) & $\begin{array}{l}\text { How do incumbent firms } \\
\text { use relational } \\
\text { discrimination to manage } \\
\text { threats from market } \\
\text { entry? }\end{array}$ & Organization & $\mathrm{S}, \mathrm{O}$ & $\begin{array}{l}\text { Empirical } \\
\text { quantitative }\end{array}$ & $\begin{array}{l}\text { Data on commercial banks' } \\
\text { entry into investment } \\
\text { banking in the period } 1991 \text { to } \\
1997\end{array}$ & $\begin{array}{l}\text { Incumbent firms seeking } \\
\text { collaborators switch between } \\
\text { favoring and disfavoring entering } \\
\text { firms compared to incumbent firms } \\
\text { depending on their social status and } \\
\text { brokerage opportunities. }\end{array}$ & $\begin{array}{l}\text { Lead manager } \\
\text { investment bank's } \\
\text { choice of } \\
\text { management } \\
\text { partner }\end{array}$ \\
\hline $\begin{array}{l}\text { Jonczyk, Lee, } \\
\text { Galunic, \& } \\
\text { Bensaou } \\
(2016)\end{array}$ & $\begin{array}{l}\text { Does the prior structural } \\
\text { position occupied by an } \\
\text { individual influence ties } \\
\text { gain and loss during role } \\
\text { transitions? }\end{array}$ & Individual & $\mathrm{S}, \mathrm{O}, \mathrm{M}, \mathrm{D}$ & $\begin{array}{l}\text { Empirical } \\
\text { quantitative }\end{array}$ & $\begin{array}{l}\text { Newly promoted } \\
\text { professionals in three } \\
\text { professional service firms } \\
\text { (PSFs) }\end{array}$ & $\begin{array}{l}\text { The entire (extant) network of } \\
\text { professional relationships shapes the } \\
\text { way people reconfigure their } \\
\text { workplace relations during a role } \\
\text { transition }\end{array}$ & $\begin{array}{l}\text { Cognitive ad } \\
\text { emotional trust }\end{array}$ \\
\hline
\end{tabular}


NETWORK BROKERAGE 69

\begin{tabular}{|c|c|c|c|c|c|c|c|}
\hline Author(s) & Research question(s) & $\begin{array}{l}\text { Level(s) of } \\
\text { analysis }\end{array}$ & $\begin{array}{c}\text { Categories of } \\
\text { factors }\end{array}$ & $\begin{array}{l}\text { Type of } \\
\text { article }\end{array}$ & Sample & Findings/Conclusions & Outcomes \\
\hline $\begin{array}{l}\text { Kalish \& } \\
\text { Robins (2006) }\end{array}$ & $\begin{array}{l}\text { How do individual } \\
\text { differences predispose } \\
\text { actors to structure their } \\
\text { social environment by } \\
\text { seeking network closure } \\
\text { or by sustaining } \\
\text { structural holes? }\end{array}$ & Individual & $\mathrm{A}, \mathrm{S}$ & $\begin{array}{l}\text { Empirical } \\
\text { quantitative }\end{array}$ & $\begin{array}{l}125 \text { egocentric network of } \\
\text { university students }\end{array}$ & $\begin{array}{l}\text { People who seek to keep their strong } \\
\text { tie partners apart, and thereby bridge } \\
\text { structural holes, tend to be } \\
\text { individualists, to believe that they } \\
\text { control the events in their lives, and } \\
\text { to have higher levels of neuroticism. } \\
\text { People who focus on being different } \\
\text { from others, including others in their } \\
\text { own "social group", are more likely } \\
\text { to have separated strong tie partners. } \\
\text { It takes a belief in one's own agentic } \\
\text { capacity to keep strong partners apart } \\
\text { and to have weak ties going to parts } \\
\text { of the social world distinct from } \\
\text { one's own personal network. }\end{array}$ & - \\
\hline $\begin{array}{l}\text { Kaplan, Milde, } \\
\text { \& Cowan } \\
(2017)\end{array}$ & $\begin{array}{l}\text { How do interdisciplinary } \\
\text { collaborations take place } \\
\text { in the context of } \\
\text { cognitive structures and } \\
\text { political economies } \\
\text { anchored in the } \\
\text { disciplines? In other } \\
\text { words, how are cognitive } \\
\text { and political boundaries } \\
\text { spanned simultaneously? }\end{array}$ & Individual & $\mathrm{B}$ & $\begin{array}{l}\text { Empirical } \\
\text { qualitative }\end{array}$ & $\begin{array}{l}\text { A field study of a U.S. } \\
\text { National Science } \\
\text { Foundation-funded } \\
\text { interdisciplinary research } \\
\text { center in the emerging field } \\
\text { of nanotechnology }\end{array}$ & $\begin{array}{l}\text { The interdisciplinary boundaries } \\
\text { were spanned by students who, } \\
\text { because they had the least to lose, } \\
\text { had the capacity to make the } \\
\text { investments in knowledge and take } \\
\text { the additional career risks associated } \\
\text { with learning the instruments that } \\
\text { would allow interdisciplinary } \\
\text { research to take place. }\end{array}$ & - \\
\hline $\begin{array}{l}\text { Kauppila, } \\
\text { Bizzi, \& } \\
\text { Obstfeld } \\
(2018)\end{array}$ & $\begin{array}{l}\text { How does tertius iungens } \\
\text { orientation influence } \\
\text { employee's creativity? }\end{array}$ & Individual & $\mathrm{B}, \mathrm{O}, \mathrm{M}$ & $\begin{array}{l}\text { Empirical } \\
\text { quantitative }\end{array}$ & $\begin{array}{l}638 \text { employees and } 192 \\
\text { middle managers from } 34 \\
\text { organizations located in } \\
\text { Finland }\end{array}$ & $\begin{array}{l}\text { When top managers consider a } \\
\text { narrower range of options and act } \\
\text { more quickly to respond to } \\
\text { challenges in the external } \\
\text { environment, they risk constraining } \\
\text { creative processes within the } \\
\text { organization. }\end{array}$ & $\begin{array}{l}\text { Creative } \\
\text { performance }\end{array}$ \\
\hline $\begin{array}{l}\text { Kilduff, } \\
\text { Crossland, } \\
\text { Tsai, \& } \\
\text { Krackhardt } \\
(2008)\end{array}$ & $\begin{array}{l}\text { How do people keep } \\
\text { track of and make sense } \\
\text { of social network } \\
\text { connections in } \\
\text { organizational settings? }\end{array}$ & Individual & $\mathrm{A}, \mathrm{S}$ & $\begin{array}{l}\text { Empirical } \\
\text { quantitative }\end{array}$ & $\begin{array}{l}116 \text { perceived friendship } \\
\text { networks from four different } \\
\text { organizations }\end{array}$ & $\begin{array}{l}\text { In order to organize and recall } \\
\text { complex social structures such as } \\
\text { organizational friendship networks, } \\
\text { people appear to bias perceptions } \\
\text { toward more clustering, together with } \\
\text { greater centralization and brokerage } \\
\text { for perceivedly-central people. }\end{array}$ & - \\
\hline $\begin{array}{l}\text { Kirkels \& } \\
\text { Duysters } \\
(2010)\end{array}$ & $\begin{array}{l}\text { What makes a broker so } \\
\text { valuable? }\end{array}$ & Individual & $\mathrm{A}, \mathrm{S}, \mathrm{B}, \mathrm{M}$ & $\begin{array}{l}\text { Empirical } \\
\text { quantitative }\end{array}$ & $\begin{array}{l}\text { Survey to } 93 \text { respondents } \\
\text { from SMEs in Netherlands }\end{array}$ & $\begin{array}{l}\text { The most influential brokers are } \\
\text { found in the non-profit and science } \\
\text { sector and have a long track record in } \\
\text { their branch. }\end{array}$ & - \\
\hline
\end{tabular}


NETWORK BROKERAGE 70

\begin{tabular}{|c|c|c|c|c|c|c|c|}
\hline Author(s) & Research question(s) & $\begin{array}{l}\text { Level(s) of } \\
\text { analysis }\end{array}$ & $\begin{array}{c}\text { Categories of } \\
\text { factors }\end{array}$ & $\begin{array}{l}\text { Type of } \\
\text { article }\end{array}$ & Sample & Findings/Conclusions & Outcomes \\
\hline $\begin{array}{l}\text { Kleinbaum } \\
(2012)\end{array}$ & $\begin{array}{l}\text { How do career processes } \\
\text { shape network structure? }\end{array}$ & Individual & $\mathrm{A}, \mathrm{S}, \mathrm{M}$ & $\begin{array}{l}\text { Empirical } \\
\text { quantitative }\end{array}$ & $\begin{array}{l}\text { Career history data recorded } \\
\text { longitudinally for } 30,000 \\
\text { employees in a large } \\
\text { information technology firm }\end{array}$ & $\begin{array}{l}\text { "Organizational misfits"-people } \\
\text { who followed career trajectories that } \\
\text { are atypical in their organization- } \\
\text { have access to more valuable } \\
\text { brokerage opportunities than those } \\
\text { whose careers followed more } \\
\text { conventional paths. }\end{array}$ & - \\
\hline $\begin{array}{l}\text { Kleinbaum } \\
(2018)\end{array}$ & $\begin{array}{l}\text { In the face of the } \\
\text { changing interaction } \\
\text { opportunities that occur } \\
\text { in a reorganization, } \\
\text { which ties do people } \\
\text { choose to retain and } \\
\text { which ties do they allow } \\
\text { to decay? }\end{array}$ & Individual & $\mathrm{A}, \mathrm{S}, \mathrm{O}, \mathrm{D}$ & $\begin{array}{l}\text { Empirical } \\
\text { quantitative }\end{array}$ & $\begin{array}{l}\text { Network ties among students } \\
\text { in a full-time, residential } \\
\text { MBA program at an elite, } \\
\text { private university in the } \\
\text { northeastern United States }\end{array}$ & $\begin{array}{l}\text { Deliberate choice plays a more } \\
\text { prominent role in tie decay than it } \\
\text { does in tie formation. People } \\
\text { (especially those with Machiavellian } \\
\text { personalities) choose to retain ties to } \\
\text { valuable contacts, they retain } \\
\text { reciprocated ties (especially with } \\
\text { highly empathic others), and they } \\
\text { retain socially embedded ties } \\
\text { (especially low self-monitors). }\end{array}$ & Dyadic tie decay \\
\hline $\begin{array}{l}\text { Kleinbaum, } \\
\text { Jordan, \& } \\
\text { Audia (2015) }\end{array}$ & $\begin{array}{l}\text { Where does brokerage } \\
\text { come from? }\end{array}$ & Individual & $\mathrm{A}, \mathrm{S}$ & $\begin{array}{l}\text { Empirical } \\
\text { quantitative }\end{array}$ & $\begin{array}{l}\text { Survey to } 268 \text { first-year } \\
\text { MBA students at a private } \\
\text { East Coast university }\end{array}$ & $\begin{array}{l}\text { The focal actor's perceived empathy } \\
\text { and self-monitoring personality } \\
\text { interact positively in their effect on } \\
\text { others' reciprocation of the actor's } \\
\text { social advances. }\end{array}$ & - \\
\hline $\begin{array}{l}\text { Koka \& } \\
\text { Prescott } \\
(2008)\end{array}$ & $\begin{array}{l}\text { How do alliance network } \\
\text { positions influence firm } \\
\text { performance? }\end{array}$ & Organization & $\mathrm{S}, \mathrm{O}, \mathrm{M}, \mathrm{D}$ & $\begin{array}{l}\text { Empirical } \\
\text { quantitative }\end{array}$ & $\begin{array}{l}\text { Strategic alliances formed in } \\
\text { the steel industry, } 1980-1994\end{array}$ & $\begin{array}{l}\text { Following an environmental change } \\
\text { event in the steel industry, alliance } \\
\text { networks that were more } \\
\text { entrepreneurial performed better, } \\
\text { while those that were more } \\
\text { prominent suffered performance } \\
\text { decline. However, when the change } \\
\text { was radical, both types of alliance } \\
\text { networks were negatively related to } \\
\text { performance. }\end{array}$ & Productivity \\
\hline $\begin{array}{l}\text { Landis, } \\
\text { Kilduff, } \\
\text { Menges, \& } \\
\text { Kilduff (2018) }\end{array}$ & $\begin{array}{l}\text { Do some people who } \\
\text { have access to brokerage } \\
\text { opportunities fail to } \\
\text { perceive them? }\end{array}$ & Individual & $\mathrm{A}, \mathrm{S}$ & $\begin{array}{l}\text { Empirical } \\
\text { quantitative }\end{array}$ & $\begin{array}{l}\text { Employees in a marketing } \\
\text { and media agency \& } 330 \\
\text { full-time U.S. employees } \\
\text { from Amazon's Mechanical } \\
\text { Turk (MTurk) }\end{array}$ & $\begin{array}{l}\text { The psychological experience of } \\
\text { power diminishes individuals' ability } \\
\text { to perceive opportunities to broker } \\
\text { between people who are not directly } \\
\text { connected in their networks, yet } \\
\text { enhances their willingness to broker. }\end{array}$ & - \\
\hline
\end{tabular}


NETWORK BROKERAGE 71

\begin{tabular}{|c|c|c|c|c|c|c|c|}
\hline Author(s) & Research question(s) & $\begin{array}{l}\text { Level(s) of } \\
\text { analysis }\end{array}$ & $\begin{array}{c}\text { Categories of } \\
\text { factors }\end{array}$ & $\begin{array}{l}\text { Type of } \\
\text { article }\end{array}$ & Sample & Findings/Conclusions & Outcomes \\
\hline Lee (2007) & $\begin{array}{l}\text { (1) How do network } \\
\text { resources, derived from } \\
\text { pre-entry interfirm } \\
\text { relationships, affect a } \\
\text { firm's timing of entry } \\
\text { into an emerging product } \\
\text { market? (2) More } \\
\text { importantly, what are the } \\
\text { advantages/drawbacks of } \\
\text { a firm's net- work } \\
\text { resources on the timing } \\
\text { of market entry? }\end{array}$ & Organization & $\mathrm{S}, \mathrm{O}$ & $\begin{array}{l}\text { Empirical } \\
\text { quantitative }\end{array}$ & $\begin{array}{l}\text { CorpTech Directory on } \\
\text { 'Who Makes What'. This } \\
\text { directory, published annually } \\
\text { starting in } 1987 \text {, provides } \\
\text { product listings by firm, by } \\
\text { product code, and by year for } \\
\text { about } 50,000 \text { high- } \\
\text { technology manufacturing } \\
\text { establishments }\end{array}$ & $\begin{array}{l}\text { Brokerage increases the quantity of } \\
\text { information through partners that are } \\
\text { directly connected to the focal firm. }\end{array}$ & $\begin{array}{l}\text { The amount of } \\
\text { time elapsed } \\
\text { between the } \\
\text { emergence of the } \\
\text { networking } \\
\text { switches market } \\
\text { and a firm's entry } \\
\text { event, or } \\
\text { censoring. }\end{array}$ \\
\hline Lee (2010) & $\begin{array}{l}\text { How does the } \\
\text { heterogeneity in actor } \\
\text { attributes - such as } \\
\text { performance history - } \\
\text { generate differences in } \\
\text { network positions? }\end{array}$ & Individual & A, S, O & $\begin{array}{l}\text { Empirical } \\
\text { quantitative }\end{array}$ & $\begin{array}{l}\text { 57,605 U.S. patents by } \\
28,267 \text { U.S. biotech } \\
\text { inventors during 1976-1995 } \\
\text { (Database: National Bureau } \\
\text { of Economic Research } \\
\text { (NBER) patent data set) }\end{array}$ & $\begin{array}{l}\text { High-performing inventors are more } \\
\text { apt to form collaboration ties that } \\
\text { increase brokerage. The strength of } \\
\text { the brokering position - patent } \\
\text { performance association - is reduced } \\
\text { controlling for actor's past } \\
\text { performance and disappears when } \\
\text { inventor-level heterogeneity is } \\
\text { controlled for through inventor fixed } \\
\text { effects. }\end{array}$ & $\begin{array}{l}\text { Collaboration tie } \\
\text { formation and } \\
\text { performance } \\
\text { (simple patent } \\
\text { counts } \\
\text { and citation- } \\
\text { weighted patent } \\
\text { counts as } \\
\text { measures of } \\
\text { performance) }\end{array}$ \\
\hline $\begin{array}{l}\text { Levin, Walter, } \\
\text { Appleyard, \& } \\
\text { Cross (2016) }\end{array}$ & $\begin{array}{l}\text { How does a relational } \\
\text { dimension of social } \\
\text { capital work with a } \\
\text { structural dimension? }\end{array}$ & Individual & $\mathrm{S}, \mathrm{O}, \mathrm{M}$ & $\begin{array}{l}\text { Empirical } \\
\text { quantitative }\end{array}$ & $\begin{array}{l}\text { Networks in a consulting } \\
\text { firm and the engineering } \\
\text { division of a large } \\
\text { manufacturer }\end{array}$ & $\begin{array}{l}\text { A network-bridging tie yields more } \\
\text { value when it is also strong. Trust is } \\
\text { identified as the key mechanism } \\
\text { allowing network actors to unlock the } \\
\text { value embedded in their network- } \\
\text { bridging ties. }\end{array}$ & $\begin{array}{l}\text { Revenue } \\
\text { production and the } \\
\text { receipt of useful } \\
\text { knowledge }\end{array}$ \\
\hline $\begin{array}{l}\mathrm{Li}, \mathrm{Li}, \mathrm{Guo} \\
\mathrm{Li}, \& \text { Harris } \\
(2018)\end{array}$ & $\begin{array}{l}\text { What are the conditions } \\
\text { under which teams } \\
\text { actually promote } \\
\text { individuals' creativity? }\end{array}$ & Individual & $\mathrm{S}, \mathrm{O}, \mathrm{M}$ & $\begin{array}{l}\text { Empirical } \\
\text { mixed } \\
\text { methods }\end{array}$ & $\begin{array}{l}\text { Teams from manufacturing } \\
\text { firms }\end{array}$ & $\begin{array}{l}\text { Brokerage in a team's } \\
\text { advice-giving network is a critical } \\
\text { antecedent of creativity for advice } \\
\text { recipients and givers }\end{array}$ & Creativity \\
\hline $\begin{array}{l}\text { Lingo \& } \\
\text { O’Mahony } \\
\text { (2010) }\end{array}$ & $\begin{array}{l}\text { How do brokers on } \\
\text { creative projects integrate } \\
\text { the ideas of others? }\end{array}$ & Individual & $\mathrm{S}, \mathrm{B}, \mathrm{O}, \mathrm{M}$ & $\begin{array}{l}\text { Empirical } \\
\text { qualitative }\end{array}$ & $\begin{array}{l}23 \text { independent music } \\
\text { producers in the Nashville } \\
\text { country music industry }\end{array}$ & $\begin{array}{l}\text { Producers interwove tertius gaudens } \\
\text { and tertius iungens approaches } \\
\text { throughout the creative process, } \\
\text { pursuing a dialectic approach to } \\
\text { managing the dualities of generating } \\
\text { creative options and synthesizing } \\
\text { them into a cohesive whole. Thus, } \\
\text { tertius gaudens behavior can be used } \\
\text { to benefit the collective, not just a } \\
\text { broker. }\end{array}$ & $\begin{array}{l}\text { Collective } \\
\text { creative outcome }\end{array}$ \\
\hline
\end{tabular}


NETWORK BROKERAGE 72

\begin{tabular}{|c|c|c|c|c|c|c|c|}
\hline Author(s) & Research question(s) & $\begin{array}{l}\text { Level(s) of } \\
\text { analysis }\end{array}$ & $\begin{array}{c}\text { Categories of } \\
\text { factors }\end{array}$ & $\begin{array}{l}\text { Type of } \\
\text { article }\end{array}$ & Sample & Findings/Conclusions & Outcomes \\
\hline Maak (2007) & $\begin{array}{l}\text { (1) How can business } \\
\text { leadership become more } \\
\text { responsible? (2) How can } \\
\text { businesses contribute to } \\
\text { tackling some of the } \\
\text { world's most pressing } \\
\text { problems? (3) What are } \\
\text { today's and tomorrow's } \\
\text { challenges of leading } \\
\text { responsibly in a global } \\
\text { stakeholder society? }\end{array}$ & $\begin{array}{l}\text { Individual, } \\
\text { Organization }\end{array}$ & $\mathrm{A}, \mathrm{S}, \mathrm{B}, \mathrm{O}, \mathrm{M}$ & Conceptual & - & $\begin{array}{l}\text { A leader is key in engaging } \\
\text { stakeholders, in co-opting them to } \\
\text { realize a mutually desirable vision } \\
\text { and in connecting them for the } \\
\text { purpose of responsible change-- } \\
\text { thereby bridging potential structural } \\
\text { holes. Responsible leaders weave } \\
\text { durable relational structures and } \\
\text { ultimately networks of relationships } \\
\text { which are rich in ties to otherwise } \\
\text { unconnected individuals or groups } \\
\text { resulting in the creation of value } \\
\text { networks. }\end{array}$ & Social capital \\
\hline $\begin{array}{l}\text { Madhavan, } \\
\text { Gnyawali, \& } \\
\text { He (2004) }\end{array}$ & $\begin{array}{l}\text { Do competitor alliance } \\
\text { networks demonstrate a } \\
\text { structural tendency } \\
\text { toward transitive triads? } \\
\text { In competitor alliance } \\
\text { networks, is there a } \\
\text { greater structural } \\
\text { tendency for transitive } \\
\text { triads to be formed } \\
\text { among firms within a } \\
\text { geographic region than } \\
\text { among firms across } \\
\text { regions? In competitor } \\
\text { alliance networks, is } \\
\text { there a greater structural } \\
\text { tendency for transitive } \\
\text { triads to be formed } \\
\text { among firms within a } \\
\text { technological group than } \\
\text { among firms across } \\
\text { technological groups? }\end{array}$ & Organization & $A, S$ & $\begin{array}{l}\text { Empirical } \\
\text { quantitative }\end{array}$ & $\begin{array}{l}\text { A competitor network } \\
\text { consisting of } 45 \text { global steel } \\
\text { producers that had entered } \\
\text { into } 72 \text { strategic alliances } \\
\text { during the period } 1979-94 \text {. }\end{array}$ & $\begin{array}{l}\text { Firms tend to form transitive triads, } \\
\text { in which three firms all have direct } \\
\text { ties with each other, especially within } \\
\text { blocks defined by geography or } \\
\text { technology. }\end{array}$ & - \\
\hline $\begin{array}{l}\text { Maguire, } \\
\text { Hardy, \& } \\
\text { Lawrence } \\
(2004)\end{array}$ & $\begin{array}{l}\text { How do the activities that } \\
\text { constitute institutional } \\
\text { entrepreneurship vary in } \\
\text { different contexts? }\end{array}$ & Organization & $\mathrm{A}, \mathrm{S}, \mathrm{B}, \mathrm{O}, \mathrm{M}$ & $\begin{array}{l}\text { Empirical } \\
\text { qualitative }\end{array}$ & $\begin{array}{l}\text { Single case study, interviews } \\
\text { representatives of } \\
\text { pharmaceutical companies } \\
\text { and representatives of } \\
\text { community organizations }\end{array}$ & $\begin{array}{l}\text { Institutional entrepreneurs in } \\
\text { emerging fields will possess } \\
\text { legitimacy with respect to diverse } \\
\text { stakeholders and bridge diverse } \\
\text { stakeholders and to access dispersed } \\
\text { sets of resources. }\end{array}$ & $\begin{array}{l}\text { Institutional } \\
\text { entrepreneurs in } \\
\text { emerging field }\end{array}$ \\
\hline
\end{tabular}


NETWORK BROKERAGE 73

\begin{tabular}{|c|c|c|c|c|c|c|c|}
\hline Author(s) & Research question(s) & $\begin{array}{l}\text { Level(s) of } \\
\text { analysis }\end{array}$ & $\begin{array}{c}\text { Categories of } \\
\text { factors }\end{array}$ & $\begin{array}{l}\text { Type of } \\
\text { article }\end{array}$ & Sample & Findings/Conclusions & Outcomes \\
\hline $\begin{array}{l}\text { Marineau, } \\
\text { Labianca, \& } \\
\text { Kane (2016) }\end{array}$ & $\begin{array}{l}\text { How do negative tie } \\
\text { affect individual } \\
\text { performance? }\end{array}$ & $\begin{array}{l}\text { Individual, } \\
\text { Intra- } \\
\text { organization }\end{array}$ & $\mathrm{S}, \mathrm{O}$ & $\begin{array}{l}\text { Empirical } \\
\text { quantitative }\end{array}$ & $\begin{array}{l}\text { Social network data from } \\
183 \text { members of a division of } \\
\text { a midsized Midwestern U.S. } \\
\text { life sciences firm }\end{array}$ & $\begin{array}{l}\text { When person B has a negative tie } \\
\text { from person C, actor A then has the } \\
\text { power to leverage exchanges with B, } \\
\text { who is otherwise relegated to } \\
\text { unproductive or even detrimental } \\
\text { exchanges with } \mathrm{C} \text { (in the PN open } \\
\text { triad). Thus, negative ties may } \\
\text { benefit those who are well-positioned } \\
\text { to intentionally or unintentionally } \\
\text { capitalize on the opportunities made } \\
\text { available by the dependent alters. }\end{array}$ & Job performance \\
\hline $\begin{array}{l}\text { McDermott, } \\
\text { Correidora, \& } \\
\text { Kruse (2009) }\end{array}$ & $\begin{array}{l}\text { What are the types of } \\
\text { institutional mechanisms } \\
\text { that help firms access a } \\
\text { variety of knowledge } \\
\text { resources and learn? }\end{array}$ & Organization & $\mathrm{S}, \mathrm{O}$ & $\begin{array}{l}\text { Empirical } \\
\text { mixed } \\
\text { methods }\end{array}$ & $\begin{array}{l}\text { Multimethod analysis of the } \\
\text { recent transformation of the } \\
\text { Argentine wine industry }\end{array}$ & $\begin{array}{l}\text { Firms with more numerous ties to } \\
\text { other firms, and particularly } \\
\text { Mendoza's new GSis, will have } \\
\text { higher levels of product upgrading } \\
\text { than those tied to other types of } \\
\text { organizations. These mediating firms } \\
\text { and GSis have particular value } \\
\text { because of their centrality and } \\
\text { bridging qualities that offer focal } \\
\text { firms access to a variety of } \\
\text { knowledge resources. }\end{array}$ & Product upgrading \\
\hline $\begin{array}{l}\text { McEvily \& } \\
\text { Zaheer (1999) }\end{array}$ & $\begin{array}{l}\text { What explains } \\
\text { differences in firms' } \\
\text { abilities to acquire } \\
\text { competitive capabilities? }\end{array}$ & Organization & $\mathrm{S}, \mathrm{O}$ & $\begin{array}{l}\text { Empirical } \\
\text { quantitative }\end{array}$ & $\begin{array}{l}\text { Stratified random sample of } \\
227 \text { job shop manufacturers } \\
\text { located in the U.S. Midwest }\end{array}$ & $\begin{array}{l}\text { Firms in geographical clusters that } \\
\text { maintain networks rich in bridging } \\
\text { ties and sustain ties to regional } \\
\text { institutions are well positioned to } \\
\text { access new information, ideas, and } \\
\text { opportunities. }\end{array}$ & $\begin{array}{l}\text { Acquisition of } \\
\text { competitive } \\
\text { capabilities. }\end{array}$ \\
\hline $\begin{array}{l}\text { McEvily, } \\
\text { Jaffee, \& } \\
\text { Tortoriello } \\
(2012)\end{array}$ & $\begin{array}{l}\text { Are there brokerage } \\
\text { benefits that persist over } \\
\text { an extended period of } \\
\text { time? What type of } \\
\text { network dynamics might } \\
\text { account for such } \\
\text { enduring benefits? }\end{array}$ & $\begin{array}{l}\text { Individual, } \\
\text { Organization }\end{array}$ & $\mathrm{S}, \mathrm{O}, \mathrm{D}$ & $\begin{array}{l}\text { Empirical } \\
\text { quantitative }\end{array}$ & $\begin{array}{l}\text { Formation and evolution of } \\
\text { the professional network of } \\
\text { lawyers' coemployment ties } \\
\text { in the Nashville's legal } \\
\text { industry between } 1933 \text { and } \\
1978 .\end{array}$ & $\begin{array}{l}\text { Bridging ties produce network } \\
\text { benefits over an extended period of } \\
\text { time and trace back to the point of tie } \\
\text { formation. The imprinted effect is } \\
\text { more robust than the rapidly } \\
\text { decaying effect of bridging ties. }\end{array}$ & Firm growth rate \\
\hline $\begin{array}{l}\text { McFadyen, } \\
\text { Semadeni, \& } \\
\text { Cannella } \\
(2009)\end{array}$ & $\begin{array}{l}\text { How do network } \\
\text { structural characteristics } \\
\text { (ego network density and } \\
\text { average tie strength) } \\
\text { affect knowledge } \\
\text { creation? }\end{array}$ & Individual & $\mathrm{S}, \mathrm{O}, \mathrm{M}$ & $\begin{array}{l}\text { Empirical } \\
\text { quantitative }\end{array}$ & $\begin{array}{l}177 \text { university biomedical } \\
\text { research scientists over an } \\
11 \text {-year period }\end{array}$ & $\begin{array}{l}\text { Knowledge workers with mostly } \\
\text { strong ties to their direct exchange } \\
\text { partners, coupled with exchange } \\
\text { partners who tend not to be directly } \\
\text { connected to each other, should lead } \\
\text { to the highest levels of knowledge } \\
\text { creation. }\end{array}$ & $\begin{array}{l}\text { Knowledge } \\
\text { creation }\end{array}$ \\
\hline
\end{tabular}


NETWORK BROKERAGE 74

\begin{tabular}{|c|c|c|c|c|c|c|c|}
\hline Author(s) & Research question(s) & $\begin{array}{l}\text { Level(s) of } \\
\text { analysis }\end{array}$ & $\begin{array}{c}\text { Categories of } \\
\text { factors }\end{array}$ & $\begin{array}{l}\text { Type of } \\
\text { article }\end{array}$ & Sample & Findings/Conclusions & Outcomes \\
\hline $\begin{array}{l}\text { Mosey \& } \\
\text { Wright (2007) }\end{array}$ & $\begin{array}{l}\text { How do differences in } \\
\text { the human capital } \\
\text { derived from the } \\
\text { entrepreneurial } \\
\text { experience of academic } \\
\text { entrepreneurs influence } \\
\text { their ability to develop } \\
\text { social capital? }\end{array}$ & $\begin{array}{l}\text { Individual, } \\
\text { Group }\end{array}$ & $\mathrm{S}, \mathrm{B}, \mathrm{O}$ & $\begin{array}{l}\text { Empirical } \\
\text { qualitative }\end{array}$ & $\begin{array}{l}44 \text { interviews with } \\
\text { academics, business } \\
\text { development officers, and } \\
\text { heads of schools involved in } \\
\text { the process of new venture } \\
\text { creation within } 10 \text { schools of } \\
\text { engineering or applied } \\
\text { science in } 6 \text { U.K. } \\
\text { Universities }\end{array}$ & $\begin{array}{l}\text { Structural hole exists between } \\
\text { scientific research networks and } \\
\text { industry networks that constrains } \\
\text { opportunity recognition. Less } \\
\text { experienced academic entrepreneurs } \\
\text { encounter structural holes between } \\
\text { their scientific research networks and } \\
\text { industry networks that constrain } \\
\text { opportunity recognition. Technology } \\
\text { transfer office play a "brokering" } \\
\text { role, bridge a structural hole by } \\
\text { drafting formal partnership } \\
\text { agreements with potential industry } \\
\text { partners, from whom entrepreneurs } \\
\text { gained proof of concept funding, } \\
\text { facilities, and industry knowledge. }\end{array}$ & Social capital \\
\hline $\begin{array}{l}\text { Nerkar \& } \\
\text { Paruchuri } \\
(2005)\end{array}$ & $\begin{array}{l}\text { What are the mechanisms } \\
\text { through which } \\
\text { knowledge is selected for } \\
\text { recombination? }\end{array}$ & $\begin{array}{l}\text { Individual, } \\
\text { Intra- } \\
\text { organization }\end{array}$ & $\mathrm{S}, \mathrm{O}, \mathrm{M}$ & $\begin{array}{l}\text { Empirical } \\
\text { quantitative }\end{array}$ & $\begin{array}{l}10,908 \text { patents issued by } \\
\text { DuPont, a Fortune } 500 \\
\text { chemical company, between } \\
1972-1998\end{array}$ & $\begin{array}{l}\text { The extent of structural holes } \\
\text { spanned by an inventor in an intra- } \\
\text { organizational knowledge network } \\
\text { will be positively associated with the } \\
\text { likelihood of their knowledge being } \\
\text { selected by other inventors. The } \\
\text { relationship between the centrality of } \\
\text { an inventor in an intra-organizational } \\
\text { knowledge network and the } \\
\text { likelihood of his or her knowledge } \\
\text { being used by other inventors is } \\
\text { positively moderated by the extent to } \\
\text { which this inventor spans structural } \\
\text { holes in the network. }\end{array}$ & $\begin{array}{l}\text { Rate of intrafirm } \\
\text { citation to a patent } \\
\text { by inventors other } \\
\text { than those who } \\
\text { are involved in its } \\
\text { creation }\end{array}$ \\
\hline $\begin{array}{l}\text { O'Connor \& } \\
\text { Gladstone } \\
\text { (2018) }\end{array}$ & $\begin{array}{l}\text { Is attractiveness linked to } \\
\text { people's preferences for } \\
\text { positions in networks? }\end{array}$ & Individual & $\mathrm{A}, \mathrm{S}$ & $\begin{array}{l}\text { Empirical } \\
\text { mixed } \\
\text { methods }\end{array}$ & $\begin{array}{l}\text { (1) experiment with } 124 \\
\text { MBA participants from an } \\
\text { experiment database (2) } \\
\text { network data from } 62 \mathrm{MBA} \\
\text { students from a U.S. } \\
\text { university in the Northeast }\end{array}$ & $\begin{array}{l}\text { More attractive people were more } \\
\text { likely to select for themselves more } \\
\text { profitable broker positions in } \\
\text { networks relative to other positions } \\
\text { and relative to less attractive people. }\end{array}$ & - \\
\hline $\begin{array}{l}\text { O’ Mahony \& } \\
\text { Bechky (2006) }\end{array}$ & $\begin{array}{l}\text { How do contract workers } \\
\text { manage the career } \\
\text { progression paradox, the } \\
\text { problem of finding a job } \\
\text { without prior experience? }\end{array}$ & Individual & $\mathrm{S}, \mathrm{B}, \mathrm{O}, \mathrm{M}$ & $\begin{array}{l}\text { Empirical } \\
\text { qualitative }\end{array}$ & $\begin{array}{l}\text { Interviews with } 61 \text { high- } \\
\text { technology U.S. contractors }\end{array}$ & $\begin{array}{l}\text { Referrals could serve as a substitute } \\
\text { for prior experience. }\end{array}$ & Career progress \\
\hline $\begin{array}{l}\text { Obstfeld } \\
(2005)\end{array}$ & $\begin{array}{l}\text { How do individuals in } \\
\text { organizations engage in } \\
\text { innovation activities? }\end{array}$ & Individual & $\mathrm{S}, \mathrm{B}, \mathrm{O}, \mathrm{D}$ & $\begin{array}{l}\text { Empirical } \\
\text { mixed } \\
\text { methods }\end{array}$ & $\begin{array}{l}\text { Survey with } 182 \text { employees } \\
\text { involved in automotive } \\
\text { design }\end{array}$ & $\begin{array}{l}\text { A tertius iungens orientation, social } \\
\text { knowledge, and social network } \\
\text { density are predictors of innovation } \\
\text { involvement within the firm. }\end{array}$ & $\begin{array}{l}\text { Involvement in } \\
\text { innovation }\end{array}$ \\
\hline
\end{tabular}


NETWORK BROKERAGE 75

\begin{tabular}{|c|c|c|c|c|c|c|c|}
\hline Author(s) & Research question(s) & $\begin{array}{l}\text { Level(s) of } \\
\text { analysis }\end{array}$ & $\begin{array}{c}\text { Categories of } \\
\text { factors }\end{array}$ & $\begin{array}{l}\text { Type of } \\
\text { article }\end{array}$ & Sample & Findings/Conclusions & Outcomes \\
\hline $\begin{array}{l}\text { Obstfeld, } \\
\text { Borgatti, \& } \\
\text { Davis }(2014)\end{array}$ & What is brokerage? & $\begin{array}{l}\text { Individual, } \\
\text { Organization }\end{array}$ & $\mathrm{S}, \mathrm{B}$ & Conceptual & - & $\begin{array}{l}\text { Broadened approach to brokerage } \\
\text { defined as "a process that alters } \\
\text { interaction between two or more } \\
\text { parties in a wide variety of triadic } \\
\text { structures" }\end{array}$ & - \\
\hline $\begin{array}{l}\text { Obukhova \& } \\
\text { Lan (2013) }\end{array}$ & $\begin{array}{l}\text { Why is the evidence from } \\
\text { job-seeker studies is } \\
\text { mixed if job seekers } \\
\text { applying through } \\
\text { referrals achieve better } \\
\text { labor-market outcomes } \\
\text { than job seekers applying } \\
\text { without referrals? }\end{array}$ & Individual & $\mathrm{S}, \mathrm{O}$ & $\begin{array}{l}\text { Empirical } \\
\text { quantitative }\end{array}$ & $\begin{array}{l}\text { The school-to-work } \\
\text { transition of } 291 \text { university } \\
\text { graduates who engaged in } \\
3,112 \text { contemporaneous job } \\
\text { searches }\end{array}$ & $\begin{array}{l}\text { Although a job seeker's social capital } \\
\text { may not affect whether or not she } \\
\text { uses contacts to search for a job, } \\
\text { using contacts as a job-search method } \\
\text { does improve her job-search } \\
\text { outcomes. }\end{array}$ & $\begin{array}{l}\text { The likelihood of } \\
\text { progressing to the } \\
\text { next stage of the } \\
\text { hiring process }\end{array}$ \\
\hline $\begin{array}{l}\text { Oh \& Kilduff } \\
(2008)\end{array}$ & $\begin{array}{l}\text { Why do some individuals } \\
\text { (rather than others) } \\
\text { occupy brokerage } \\
\text { positions? }\end{array}$ & Individual & $\mathrm{A}, \mathrm{S}$ & $\begin{array}{l}\text { Empirical } \\
\text { quantitative }\end{array}$ & $\begin{array}{l}162 \text { Korean expatriate } \\
\text { entrepreneurs in a Canadian } \\
\text { urban area }\end{array}$ & $\begin{array}{l}\text { Those high in self-monitoring tended } \\
\text { to occupy direct brokerage roles } \\
\text { within the Korean community-in } \\
\text { terms of their direct acquaintances } \\
\text { being unconnected with each other. } \\
\text { Those high in self-monitoring also } \\
\text { tended to occupy indirect brokerage } \\
\text { roles-in terms of the acquaintances } \\
\text { of their acquaintances being } \\
\text { unconnected with each other. Finally, } \\
\text { for recent arrivals, those high in self- } \\
\text { monitoring tended to establish ties to } \\
\text { a wider range of important non- } \\
\text { Korean position holders outside the } \\
\text { community. }\end{array}$ & - \\
\hline $\begin{array}{l}\text { Oh, Labianca, } \\
\& \text { Chung } \\
(2006)\end{array}$ & $\begin{array}{l}\text { How does group social } \\
\text { capital, resources made } \\
\text { available to groups } \\
\text { through social } \\
\text { relationships within and } \\
\text { outside groups, work? }\end{array}$ & Individual & $\mathrm{S}, \mathrm{O}$ & Conceptual & - & $\begin{array}{l}\text { Groups with moderate level of } \\
\text { closure and high level of bridging } \\
\text { will have the most group social } \\
\text { capital resources and, ultimately, the } \\
\text { maximum group effectiveness. }\end{array}$ & $\begin{array}{l}\text { Group } \\
\text { effectiveness }\end{array}$ \\
\hline $\begin{array}{l}\text { Opsahl, } \\
\text { Agneessens, \& } \\
\text { Skvoretz } \\
(2010)\end{array}$ & $\begin{array}{l}\text { Do centrality measures } \\
\text { need to incorporate both } \\
\text { the number of ties and } \\
\text { their tie weights when } \\
\text { applied to weighted } \\
\text { networks? }\end{array}$ & Individual & $\mathrm{S}$ & $\begin{array}{l}\text { Empirical } \\
\text { quantitative }\end{array}$ & $\begin{array}{l}\text { Freeman's EIES dataset of } \\
48 \text { researchers in } 1978\end{array}$ & $\begin{array}{l}\text { It is crucial to take both the number } \\
\text { of ties and tie weights into } \\
\text { consideration. }\end{array}$ & - \\
\hline
\end{tabular}


NETWORK BROKERAGE 76

\begin{tabular}{|c|c|c|c|c|c|c|c|}
\hline Author(s) & Research question(s) & $\begin{array}{l}\text { Level(s) of } \\
\text { analysis }\end{array}$ & $\begin{array}{c}\text { Categories of } \\
\text { factors }\end{array}$ & $\begin{array}{l}\text { Type of } \\
\text { article }\end{array}$ & Sample & Findings/Conclusions & Outcomes \\
\hline $\begin{array}{l}\text { Owen-Smith } \\
\& \text { Powell } \\
(2004)\end{array}$ & $\begin{array}{l}\text { How do important } \\
\text { nonstructural features- } \\
\text { such as the } \\
\text { characteristics of the } \\
\text { organizations that } \\
\text { represent nodes in a } \\
\text { network, geographic } \\
\text { location, or the } \\
\text { institutional } \\
\text { underpinnings of the } \\
\text { larger structure-alter the } \\
\text { character of information } \\
\text { flows? }\end{array}$ & Organization & $\mathrm{S}, \mathrm{O}, \mathrm{M}$ & $\begin{array}{l}\text { Empirical } \\
\text { quantitative }\end{array}$ & $\begin{array}{l}482 \text { dedicated biotechnology } \\
\text { firms, 1988-1999 }\end{array}$ & $\begin{array}{l}\text { The extent to which information } \\
\text { transmitted through formal linkages } \\
\text { is accessible is a function of: (1) the } \\
\text { extent to which ties are embedded in } \\
\text { a dense, regional web of formal and } \\
\text { informal affiliations, and (2) whether } \\
\text { the nodes that anchor a network } \\
\text { pursue public or private goals. }\end{array}$ & $\begin{array}{l}\text { Innovation } \\
\text { (Yearly count of } \\
\text { successful patent } \\
\text { applications) }\end{array}$ \\
\hline $\begin{array}{l}\text { Ozdemir, } \\
\text { Moran, Zhong, } \\
\text { \& Bliemel } \\
(2016)\end{array}$ & $\begin{array}{l}\text { How are some } \\
\text { entrepreneurs able to } \\
\text { obtain the resources they } \\
\text { need for their ventures, } \\
\text { while others struggle } \\
\text { only to come up with } \\
\text { little to show for their } \\
\text { efforts? }\end{array}$ & Individual & $\mathrm{B}, \mathrm{O}$ & Conceptual & - & $\begin{array}{l}\text { Entrepreneurs can better balance } \\
\text { their dual aim by structurally } \\
\text { embedding some ties rather than } \\
\text { trying to relationally embed all, } \\
\text { resulting in a meshed network that } \\
\text { combines brokerage and cohesive } \\
\text { ego-network characteristics. }\end{array}$ & $\begin{array}{l}\text { Acquisition of } \\
\text { resource }\end{array}$ \\
\hline $\begin{array}{l}\text { Podolny } \\
(2001)\end{array}$ & $\begin{array}{l}\text { How does market } \\
\text { uncertainty affect the } \\
\text { relative advantage of a } \\
\text { high-status position } \\
\text { versus a position } \\
\text { characterized by } \\
\text { numerous structural } \\
\text { holes? }\end{array}$ & Organization & $\mathrm{S}, \mathrm{O}, \mathrm{M}$ & $\begin{array}{l}\text { Empirical } \\
\text { quantitative }\end{array}$ & $\begin{array}{l}387 \text { U.S.-based financial } \\
\text { supporters of start-up } \\
\text { between 1981-1996 }\end{array}$ & $\begin{array}{l}\text { The value of structural holes } \\
\text { increases with egocentric uncertainty } \\
\text { (early stage investment), but not with } \\
\text { alter-centric uncertainty. In contrast, } \\
\text { the value of status increases with } \\
\text { alter-centric uncertainty, but declines } \\
\text { with egocentric uncertainty. }\end{array}$ & $\begin{array}{l}\text { Average } \\
\text { investment stage }\end{array}$ \\
\hline $\begin{array}{l}\text { Pollock, } \\
\text { Porac, \& } \\
\text { Wade (2004) }\end{array}$ & $\begin{array}{l}\text { how do brokers create } \\
\text { and manage structural } \\
\text { holes in mediated } \\
\text { markets? }\end{array}$ & $\begin{array}{l}\text { Individual, } \\
\text { Organization }\end{array}$ & $\mathrm{S}, \mathrm{B}, \mathrm{O}$ & Conceptual & IPO markets & $\begin{array}{l}\text { A broker's social resources and } \\
\text { dependence on the market, along } \\
\text { with exogenous deal conditions, } \\
\text { influence the broker's motivations } \\
\text { and willingness to make tradeoffs } \\
\text { between long-term and short-term } \\
\text { considerations when constructing } \\
\text { deal networks. }\end{array}$ & $\begin{array}{l}\text { Transaction } \\
\text { outcomes (IPO } \\
\text { share price and } \\
\text { allocation) }\end{array}$ \\
\hline
\end{tabular}


NETWORK BROKERAGE 77

\begin{tabular}{|c|c|c|c|c|c|c|c|}
\hline Author(s) & Research question(s) & $\begin{array}{l}\text { Level(s) of } \\
\text { analysis }\end{array}$ & $\begin{array}{c}\text { Categories of } \\
\text { factors } 4\end{array}$ & $\begin{array}{l}\text { Type of } \\
\text { article }\end{array}$ & Sample & Findings/Conclusions & Outcomes \\
\hline $\begin{array}{l}\text { Quintane \& } \\
\text { Carnabuci } \\
(2016)\end{array}$ & How do brokers broker? & Individual & $\mathrm{S}, \mathrm{B}, \mathrm{O}, \mathrm{D}$ & $\begin{array}{l}\text { Empirical } \\
\text { quantitative }\end{array}$ & $\begin{array}{l}75,308 \text { emails over a period } \\
\text { of } 35 \text { weeks between January } \\
\text { and August } 2008 \text { of } 129 \\
\text { employees in a digital- } \\
\text { agency. Replicated with } 87 \\
\text { employees in the headquarter } \\
\text { of a consulting company. }\end{array}$ & $\begin{array}{l}\text { The denser an actor's network } \\
\text { position, the stronger is the tendency } \\
\text { to broker information via one's } \\
\text { established network of long-term } \\
\text { ties. When engaging in unembedded } \\
\text { brokerage, brokers are more likely to } \\
\text { adopt a tertius gaudens strategy; } \\
\text { whereas tertius iungens strategy is } \\
\text { more likely to be adopted in } \\
\text { embedded brokerage. }\end{array}$ & $\begin{array}{l}\text { The dyad } \\
\text { composed by the } \\
\text { sender and } \\
\text { receiver of the } \\
\text { next email in the } \\
\text { sequence of } \\
\text { emails }\end{array}$ \\
\hline $\begin{array}{l}\text { Reiche, } \\
\text { Harzing, \& } \\
\text { Kraimer } \\
(2009)\end{array}$ & $\begin{array}{l}\text { How does assignees' } \\
\text { social capital translate } \\
\text { into inter-unit intellectual } \\
\text { capital? }\end{array}$ & $\begin{array}{l}\text { Individual, } \\
\text { Inter- } \\
\text { organization }\end{array}$ & $\mathrm{A}, \mathrm{S}, \mathrm{B}, \mathrm{O}, \mathrm{M}$ & Conceptual & - & $\begin{array}{l}\text { Individual social capital needs to be } \\
\text { explicitly transferred to the } \\
\text { organizational level to have a } \\
\text { sustained effect on inter-unit } \\
\text { intellectual capital. }\end{array}$ & $\begin{array}{l}\text { Interunit } \\
\text { intellectual capital }\end{array}$ \\
\hline $\begin{array}{l}\text { Reinholt, } \\
\text { Pedersen, \& } \\
\text { Foss (2011) }\end{array}$ & $\begin{array}{l}\text { How does an employee's } \\
\text { motivation and ability } \\
\text { interact with open } \\
\text { network position to share } \\
\text { knowledge? }\end{array}$ & $\begin{array}{l}\text { Intra- } \\
\text { organization }\end{array}$ & $\mathrm{S}, \mathrm{O}, \mathrm{M}$ & $\begin{array}{l}\text { Empirical } \\
\text { quantitative }\end{array}$ & $\begin{array}{l}705 \text { employees in a } \\
\text { consultancy }\end{array}$ & $\begin{array}{l}\text { Employees' knowledge acquisition } \\
\text { and provision are highest when } \\
\text { network centrality, autonomous } \\
\text { motivation, and ability are all high, } \\
\text { thus supporting the proposed three- } \\
\text { way interaction. }\end{array}$ & $\begin{array}{l}\text { Knowledge } \\
\text { acquisition and } \\
\text { provision }\end{array}$ \\
\hline $\begin{array}{l}\text { Rhee \& } \\
\text { Leonardi } \\
(2018)\end{array}$ & $\begin{array}{l}\text { Which pathway to good } \\
\text { ideas? }\end{array}$ & Individual & $\mathrm{S}, \mathrm{O}, \mathrm{M}$ & $\begin{array}{l}\text { Empirical } \\
\text { quantitative }\end{array}$ & $\begin{array}{l}\text { Survey data on } \\
\text { communication networks at a } \\
\text { software company in South } \\
\text { Korea }\end{array}$ & $\begin{array}{l}\text { For employees who wish to generate } \\
\text { good ideas, focused attention is a } \\
\text { cognitive alternative to access to } \\
\text { structural holes. }\end{array}$ & $\begin{array}{l}\text { The goodness of } \\
\text { the idea }\end{array}$ \\
\hline Rider (2009) & $\begin{array}{l}\text { How does a focal actor's } \\
\text { perceived quality } \\
\text { influence the likelihood } \\
\text { of representation by a } \\
\text { broker? }\end{array}$ & Organization & $\mathrm{B}, \mathrm{D}$ & $\begin{array}{l}\text { Empirical } \\
\text { quantitative }\end{array}$ & $\begin{array}{l}1,028 \text { venture capital funds } \\
\text { raised by } 745 \text { U.S. private } \\
\text { equity fi rms between } 2001 \\
\text { and } 2006\end{array}$ & $\begin{array}{l}\text { The likelihood that a firm's venture } \\
\text { fund is represented by a placement } \\
\text { agent first increases and then } \\
\text { decreases with firm quality, } \\
\text { measured as size, experience, and } \\
\text { status. }\end{array}$ & - \\
\hline $\begin{array}{l}\text { Rosenkopf \& } \\
\text { Almeida } \\
(2003)\end{array}$ & $\begin{array}{l}\text { How can firms reach } \\
\text { beyond their existing } \\
\text { contexts in their search } \\
\text { for new knowledge? }\end{array}$ & Organization & $\mathrm{S}, \mathrm{O}, \mathrm{M}$ & $\begin{array}{l}\text { Empirical } \\
\text { quantitative }\end{array}$ & $\begin{array}{l}\text { Patent citations in the } \\
\text { semiconductor industry }\end{array}$ & $\begin{array}{l}\text { Alliances and the mobility of } \\
\text { inventors can serve as bridges to } \\
\text { distant contexts and, thus, enable } \\
\text { firms to overcome the constraints of } \\
\text { contextually localized search. }\end{array}$ & $\begin{array}{l}\text { The likelihood } \\
\text { that a focal firm } \\
\text { will draw upon } \\
\text { the knowledge } \\
\text { stock } \\
\text { of another firm. }\end{array}$ \\
\hline Rost (2011) & $\begin{array}{l}\text { What role do strong ties } \\
\text { play in the value of } \\
\text { network brokerage in } \\
\text { terms of innovation? }\end{array}$ & Individual & $\mathrm{S}, \mathrm{O}, \mathrm{M}$ & $\begin{array}{l}\text { Empirical } \\
\text { quantitative }\end{array}$ & $\begin{array}{l}\text { Patent data for } 142 \text { inventors, } \\
2003-2010\end{array}$ & $\begin{array}{l}\text { Actors invested in strong ties and } \\
\text { also embedded in weak network } \\
\text { architectures (structural holes or a } \\
\text { peripheral network position) come up } \\
\text { with the most innovative solutions, } \\
\text { being able to recognize and realize } \\
\text { the value of accessed knowledge. }\end{array}$ & $\begin{array}{l}\text { Forward and } \\
\text { backward patent } \\
\text { citations }\end{array}$ \\
\hline
\end{tabular}


NETWORK BROKERAGE 78

\begin{tabular}{|c|c|c|c|c|c|c|c|}
\hline Author(s) & Research question(s) & $\begin{array}{l}\text { Level(s) of } \\
\text { analysis }\end{array}$ & $\begin{array}{c}\text { Categories of } \\
\text { factors }\end{array}$ & $\begin{array}{l}\text { Type of } \\
\text { article }\end{array}$ & Sample & Findings/Conclusions & Outcomes \\
\hline $\begin{array}{l}\text { Rubineau \& } \\
\text { Fernandez } \\
\text { (2013) }\end{array}$ & $\begin{array}{l}\text { How do empirically } \\
\text { documented referrer } \\
\text { behaviors affect job } \\
\text { segregation? }\end{array}$ & $\begin{array}{l}\text { Individual, } \\
\text { Organization }\end{array}$ & $\mathrm{B}, \mathrm{O}$ & $\begin{array}{l}\text { Empirical } \\
\text { quantitative }\end{array}$ & $\begin{array}{l}\text { Mathematical and } \\
\text { computational models }\end{array}$ & $\begin{array}{l}\text { Referrer behaviors can segregate jobs } \\
\text { beyond the effects of homophilous } \\
\text { network recruitment. Furthermore, } \\
\text { referrer behaviors can also mitigate } \\
\text { most, if not all, of the segregating } \\
\text { effects of network recruitment. }\end{array}$ & $\begin{array}{l}\text { The Segregating } \\
\text { Effects of } \\
\text { Network } \\
\text { Recruitment }\end{array}$ \\
\hline $\begin{array}{l}\text { Ryall \& } \\
\text { Sorenson } \\
(2007)\end{array}$ & $\begin{array}{l}\text { Does a brokerage } \\
\text { position confer a } \\
\text { competitive advantage? } \\
\text { If so, could any such } \\
\text { advantage persist if } \\
\text { actors formed relations } \\
\text { strategically? }\end{array}$ & Individual & $\mathrm{S}, \mathrm{O}, \mathrm{M}, \mathrm{D}$ & Conceptual & - & $\begin{array}{l}\text { Brokers can enjoy an advantage but } \\
\text { only if (1) they do not face } \\
\text { substitutes either for the connections } \\
\text { they offer or the value they can } \\
\text { create, (2) they intermediate more } \\
\text { than two parties, and (3) } \\
\text { interdependence does not lock them } \\
\text { into a particular pattern of exchange. }\end{array}$ & $\begin{array}{l}\text { Competitive } \\
\text { advantage of } \\
\text { brokers }\end{array}$ \\
\hline $\begin{array}{l}\text { Sapsed, } \\
\text { Grantham, \& } \\
\text { DeFillippi } \\
\text { (2007) }\end{array}$ & $\begin{array}{l}\text { how should the bridging } \\
\text { process be organized to } \\
\text { be effective? }\end{array}$ & $\begin{array}{l}\text { Inter- } \\
\text { organization }\end{array}$ & $\mathrm{B}, \mathrm{O}$ & $\begin{array}{l}\text { Empirical } \\
\text { qualitative }\end{array}$ & $\begin{array}{l}18 \text { sets of entrepreneurs } \\
\text { participating in a single } \\
\text { initiative by Wired Sussex } \\
\text { (interviews before the event, } \\
\text { during the event and after } 6 \\
\text { months) }\end{array}$ & $\begin{array}{l}\text { The effectiveness of bridging } \\
\text { organization activity depends on key } \\
\text { design choices and brokerage } \\
\text { capabilities. }\end{array}$ & $\begin{array}{l}\text { Creativity and } \\
\text { potential } \\
\text { disruptive } \\
\text { innovation }\end{array}$ \\
\hline $\begin{array}{l}\text { Sasovova, } \\
\text { Mehra, } \\
\text { Borgatti, \& } \\
\text { Schippers } \\
\text { (2010) }\end{array}$ & $\begin{array}{l}\text { Does self-monitoring } \\
\text { theory offer insight into } \\
\text { network churn and the } \\
\text { dynamics that underlie } \\
\text { network brokerage? }\end{array}$ & Individual & A, S, D & $\begin{array}{l}\text { Empirical } \\
\text { quantitative }\end{array}$ & $\begin{array}{l}170 \text { employees of the } \\
\text { radiology department of a } \\
\text { Dutch hospital }\end{array}$ & $\begin{array}{l}\text { High self-monitors are more likely to } \\
\text { occupy brokerage positions bridging } \\
\text { disconnected others in the friendship } \\
\text { networks at a given point in time and } \\
\text { to occupy new brokerage positions } \\
\text { over time. }\end{array}$ & - \\
\hline $\begin{array}{l}\text { Sgourev } \\
(2015)\end{array}$ & $\begin{array}{l}\text { how can micro and } \\
\text { macro perspectives of } \\
\text { research on networks be } \\
\text { reconciled into a } \\
\text { conceptual model } \\
\text { spanning both levels? }\end{array}$ & Individual & $\mathrm{A}, \mathrm{B}, \mathrm{O}$ & $\begin{array}{l}\text { Empirical } \\
\text { qualitative }\end{array}$ & $\begin{array}{l}\text { Case study of Ballets Russes } \\
\text { (1909-1929) (archival data) }\end{array}$ & $\begin{array}{l}\text { Through self-assembling their ties, } \\
\text { brokers may trigger chains of events } \\
\text { with systemic consequences that they } \\
\text { can only partly control or benefit } \\
\text { from. }\end{array}$ & $\begin{array}{l}\text { Viewership } \\
\text { ratings of game } \\
\text { show }\end{array}$ \\
\hline
\end{tabular}


NETWORK BROKERAGE 79

\begin{tabular}{|c|c|c|c|c|c|c|c|}
\hline Author(s) & Research question(s) & $\begin{array}{c}\text { Level(s) of } \\
\text { analysis }\end{array}$ & $\begin{array}{l}\text { Categories of } \\
\text { factors } 4\end{array}$ & $\begin{array}{l}\text { Type of } \\
\text { article }\end{array}$ & Sample & Findings/Conclusions & Outcomes \\
\hline $\begin{array}{l}\text { Shah, Levin, } \\
\text { \& Cross } \\
(2018)\end{array}$ & $\begin{array}{l}\text { Is a focal individual's } \\
\text { performance influenced } \\
\text { by the networks of his or } \\
\text { her contacts? How does } \\
\text { the network structure } \\
\text { around these contacts } \\
\text { induce the cooperation } \\
\text { that benefits the focal } \\
\text { individual's } \\
\text { performance? How does } \\
\text { this cooperation manifest } \\
\text { to benefit the focal } \\
\text { individual's } \\
\text { performance? }\end{array}$ & $\begin{array}{l}\text { Individual, } \\
\text { Intra- } \\
\text { organization }\end{array}$ & $\mathrm{S}, \mathrm{B}, \mathrm{O}$ & $\begin{array}{l}\text { Empirical } \\
\text { quantitative }\end{array}$ & $\begin{array}{l}1273 \text { research and } \\
\text { development employees } \\
\text { across } 16 \text { business units, }\end{array}$ & $\begin{array}{l}\text { The most benefit to employee } \\
\text { performance emerges from bridging } \\
\text { ties across business units (providing } \\
\text { novelty) that include secondhand } \\
\text { closure (providing cooperation). }\end{array}$ & $\begin{array}{l}\text { Employee's } \\
\text { performance }\end{array}$ \\
\hline $\begin{array}{l}\text { Shi, } \\
\text { Markoczy, \& } \\
\text { Dess (2009) }\end{array}$ & $\begin{array}{l}\text { What is the relationship } \\
\text { between eight distinct } \\
\text { brokerage roles of middle } \\
\text { managers and their } \\
\text { involvement in achieving } \\
\text { different strategic goals? }\end{array}$ & Individual & $\mathrm{S}, \mathrm{B}, \mathrm{O}$ & Conceptual & & $\begin{array}{l}\text { The study identifies eight } \\
\text { distinguished brokerage roles, } \\
\text { considering also the hierarchical } \\
\text { level of the broker in relation to } \\
\text { alters. Tertius gaudens and tertius } \\
\text { iungens orientations are } \\
\text { complementary. While the former } \\
\text { allows to access novel information, } \\
\text { the latter is crucial for its integration } \\
\text { and implementation. }\end{array}$ & $\begin{array}{l}\text { Different strategy } \\
\text { goals }\end{array}$ \\
\hline $\begin{array}{l}\text { Shi, Sun, \& } \\
\text { Peng (2012) }\end{array}$ & $\begin{array}{l}\text { (1) What is the role of a } \\
\text { local firm's network } \\
\text { position when foreign } \\
\text { entrants select } \\
\text { international joint } \\
\text { venture partners? (2) } \\
\text { How does the host } \\
\text { country's institutional } \\
\text { environment interact with } \\
\text { the role of a local firm's } \\
\text { network position as a } \\
\text { selection criterion? }\end{array}$ & $\begin{array}{l}\text { Inter- } \\
\text { organization }\end{array}$ & $\mathrm{S}, \mathrm{O}, \mathrm{M}$ & $\begin{array}{l}\text { Empirical } \\
\text { quantitative }\end{array}$ & $\begin{array}{l}\text { Electrical and information } \\
\text { technology industries in } 18 \\
\text { provinces in China, Alliance } \\
\text { data from WIND Data } \\
\text { Services, Marketization data } \\
\text { from National Economic } \\
\text { Research Institution (NERI) }\end{array}$ & $\begin{array}{l}\text { In regions where the degree of } \\
\text { marketization is low, domestic broker } \\
\text { firms are more attractive to } \\
\text { international joint venture partners. }\end{array}$ & $\begin{array}{l}\text { Likelihood of } \\
\text { selection by } \\
\text { foreign entrants as } \\
\text { an IJV partner }\end{array}$ \\
\hline
\end{tabular}


NETWORK BROKERAGE 80

\begin{tabular}{|c|c|c|c|c|c|c|c|}
\hline Author(s) & Research question(s) & $\begin{array}{l}\text { Level(s) of } \\
\text { analysis }\end{array}$ & $\begin{array}{c}\text { Categories of } \\
\text { factors }\end{array}$ & $\begin{array}{l}\text { Type of } \\
\text { article }\end{array}$ & Sample & Findings/Conclusions & Outcomes \\
\hline $\begin{array}{l}\text { Shi, Sun, } \\
\text { Pinkham, \& } \\
\text { Peng (2014) }\end{array}$ & $\begin{array}{l}\text { (1) How do foreign firms } \\
\text { observe and distinguish } \\
\text { between centrally located } \\
\text { local firms and local } \\
\text { brokers in the local } \\
\text { alliance network during } \\
\text { partner selection? (2) } \\
\text { How do foreign firms' } \\
\text { local experience and } \\
\text { perceived capabilities } \\
\text { influence their choice } \\
\text { between centrally located } \\
\text { local firms and local } \\
\text { brokers as IJV partners? }\end{array}$ & $\begin{array}{l}\text { Inter- } \\
\text { organization }\end{array}$ & $\mathrm{S}, \mathrm{O}, \mathrm{M}$ & $\begin{array}{l}\text { Empirical } \\
\text { quantitative }\end{array}$ & $\begin{array}{l}\text { Electronics and information } \\
\text { technology (IT) industries in } \\
\text { China. Alliance data: WIND } \\
\text { Data Services }\end{array}$ & $\begin{array}{l}\text { Network centrality acts as a stronger } \\
\text { network trait than brokerage in } \\
\text { attracting foreign international joint } \\
\text { venture partners. However, such } \\
\text { relationship may be moderated by } \\
\text { foreign firm's local experience and } \\
\text { perceived capabilities. When foreign } \\
\text { firms have a high level of local } \\
\text { market experience and perceived } \\
\text { capabilities, they may prefer a local } \\
\text { broker over a centrally located local } \\
\text { firm. }\end{array}$ & Partner selection \\
\hline $\begin{array}{l}\text { Shipilov } \\
\text { (2006) }\end{array}$ & $\begin{array}{l}\text { What implications does a } \\
\text { firm's specialization have } \\
\text { for the performance the } \\
\text { firm achieves by } \\
\text { spanning structural holes } \\
\text { between its partners? }\end{array}$ & Organization & $\mathrm{S}, \mathrm{O}, \mathrm{M}$ & $\begin{array}{l}\text { Empirical } \\
\text { quantitative }\end{array}$ & $\begin{array}{l}\text { Data on syndicates formed } \\
\text { by Canadian investment } \\
\text { banks for underwriting } \\
\text { public offerings between } \\
1952 \text { and } 1990\end{array}$ & $\begin{array}{l}\text { In networks rich in structural holes, } \\
\text { both specialists and generalists } \\
\text { performed better than banks of } \\
\text { moderate specialization levels, and } \\
\text { generalist banks, in turn, performed } \\
\text { better than specialists. }\end{array}$ & Market share \\
\hline $\begin{array}{l}\text { Shipilov } \\
(2009)\end{array}$ & $\begin{array}{l}\text { Can all firms benefit } \\
\text { similarly from occupying } \\
\text { network positions rich in } \\
\text { structural holes? }\end{array}$ & Organization & $\mathrm{S}, \mathrm{O}, \mathrm{M}$ & $\begin{array}{l}\text { Empirical } \\
\text { mixed } \\
\text { methods }\end{array}$ & $\begin{array}{l}\text { Interviews with } 15 \text { managers } \\
\text { involved in M\&A activities } \\
\text { and data from } 800 \text { deals } \\
\text { involving investment banks' } \\
\text { advisors on the M\&A } \\
\text { transactions in UK between } \\
1992 \text { and } 2001 \text { (Database: } \\
\text { Securities Data Corporation } \\
\text { (SDC) Thompson Financial } \\
\text { database Worldwide Mergers } \\
\text { \& Acquisitions) }\end{array}$ & $\begin{array}{l}\text { Firms with wide-scope experience, } \\
\text { organizations with high level of } \\
\text { historic MMC with partners and } \\
\text { peripheral firms perform well in open } \\
\text { networks. Structural holes have either } \\
\text { a substitute relationship with the } \\
\text { governance mechanisms and a } \\
\text { complementary relationship with } \\
\text { absorptive capacity in influencing } \\
\text { firm performance. }\end{array}$ & $\begin{array}{l}\text { Market share of } \\
\text { investment banks }\end{array}$ \\
\hline $\begin{array}{l}\text { Shipilov \& Li } \\
(2008)\end{array}$ & $\begin{array}{l}\text { Which types of a firm's } \\
\text { performance do an open } \\
\text { network actually } \\
\text { influence? }\end{array}$ & Organization & $\mathrm{S}, \mathrm{O}$ & $\begin{array}{l}\text { Empirical } \\
\text { quantitative }\end{array}$ & $\begin{array}{l}\text { Data from investment banks } \\
\text { in the United Kingdom that } \\
\text { acted as M\&A advisors } \\
\text { between } 1992 \text { and } 2001\end{array}$ & $\begin{array}{l}\text { Structural holes increase firms' status } \\
\text { accumulation but also dampen their } \\
\text { market performance. }\end{array}$ & $\begin{array}{l}\text { Market } \\
\text { performance and } \\
\text { status } \\
\text { accumulation }\end{array}$ \\
\hline $\begin{array}{l}\text { Shipilov \& Li } \\
(2012)\end{array}$ & $\begin{array}{l}\text { How are the multiplex } \\
\text { triads formed, and how } \\
\text { do they dynamically } \\
\text { evolve over time? }\end{array}$ & Organization & $\mathrm{S}, \mathrm{O}$ & $\begin{array}{l}\text { Empirical } \\
\text { quantitative }\end{array}$ & $\begin{array}{l}\text { Public securities offerings on } \\
\text { all U.S. stock exchanges } \\
\text { between January } 1,1980 \text { and } \\
\text { December } 31,2001 \text {. }\end{array}$ & $\begin{array}{l}\text { Vertical ties drive the formation of } \\
\text { horizontal relationships in a } \\
\text { multiplex triad }\end{array}$ & $\begin{array}{l}\text { Investment bank's } \\
\text { choice of } \\
\text { members in its } \\
\text { syndicate }\end{array}$ \\
\hline
\end{tabular}


NETWORK BROKERAGE 81

\begin{tabular}{|c|c|c|c|c|c|c|c|}
\hline Author(s) & Research question(s) & $\begin{array}{l}\text { Level(s) of } \\
\text { analysis }\end{array}$ & $\begin{array}{c}\text { Categories of } \\
\text { factors } \\
4\end{array}$ & $\begin{array}{l}\text { Type of } \\
\text { article }\end{array}$ & Sample & Findings/Conclusions & Outcomes \\
\hline $\begin{array}{l}\text { Shipilov, Li, } \\
\text { \& Greve } \\
(2011)\end{array}$ & $\begin{array}{l}\text { How does a brokerage } \\
\text { position coupled with } \\
\text { aspiration -performance } \\
\text { gaps affect an } \\
\text { organization's propensity } \\
\text { to initiate ties to partners } \\
\text { of different status }\end{array}$ & Organization & $\mathrm{A}, \mathrm{S}, \mathrm{O}$ & $\begin{array}{l}\text { Empirical } \\
\text { quantitative }\end{array}$ & $\begin{array}{l}\text { Public securities offerings on } \\
\text { all U.S. stock exchanges } \\
\text { between January } 1,1979 \text { and } \\
\text { December } 31,2001 \text {. }\end{array}$ & $\begin{array}{l}\text { Organizations in brokerage positions } \\
\text { are more likely than nonbrokers to } \\
\text { initiate ties to partners of different } \\
\text { status. However, when the broker } \\
\text { organization's performance deviates } \\
\text { from its aspirations, the organization } \\
\text { changes its partner selection strategy } \\
\text { and starts initiating ties to partners of } \\
\text { similar status. }\end{array}$ & $\begin{array}{l}\text { The initiation of } \\
\text { status- } \\
\text { homophilous ties }\end{array}$ \\
\hline Smith (2005) & $\begin{array}{l}\text { (1) When in possession } \\
\text { of job information and/or } \\
\text { influence, to what extent } \\
\text { are the black urban poor } \\
\text { willing to assist their job- } \\
\text { seeking ties? (2) What } \\
\text { extent are decisions to } \\
\text { assist affected by } \\
\text { properties of the } \\
\text { individual, the dyad, the } \\
\text { network, and the } \\
\text { community? }\end{array}$ & Individual & $\mathrm{A}, \mathrm{B}, \mathrm{O}, \mathrm{M}$ & $\begin{array}{l}\text { Empirical } \\
\text { mixed } \\
\text { methods }\end{array}$ & $\begin{array}{l}\text { Surveys and in-depth } \\
\text { interviews of } 105 \text { low- } \\
\text { income African-Americans }\end{array}$ & $\begin{array}{l}\text { The social capital deficiencies } \\
\text { apparent among the black urban poor } \\
\text { seem to have to do more with } \\
\text { activation or mobilization than with } \\
\text { access. }\end{array}$ & $\begin{array}{l}\text { Social capital } \\
\text { activation }\end{array}$ \\
\hline $\begin{array}{l}\text { Soda, } \\
\text { Tortoriello, \& } \\
\text { Iorio (2018) }\end{array}$ & $\begin{array}{l}\text { What is the impact of } \\
\text { different strategic } \\
\text { orientations on the } \\
\text { relationship between } \\
\text { brokerage and } \\
\text { performance.? }\end{array}$ & Individual & $\mathrm{B}, \mathrm{O}$ & $\begin{array}{l}\text { Empirical } \\
\text { quantitative }\end{array}$ & $\begin{array}{l}\text { Network survey in the HR } \\
\text { function of a large, vertically } \\
\text { integrated, global consumer } \\
\text { product company }\end{array}$ & $\begin{array}{l}\text { Arbitraging and collaborating } \\
\text { orientations have differential effects } \\
\text { on the relationship between } \\
\text { brokerage and performance, } \\
\text { significantly impacting on } \\
\text { individuals' ability to extract value } \\
\text { from brokerage. Pairing a brokerage } \\
\text { position with an arbitraging } \\
\text { orientation will be more beneficial } \\
\text { for individuals' performances, } \\
\text { whereas a brokerage position paired } \\
\text { with a collaborating orientation will } \\
\text { be less advantageous. }\end{array}$ & $\begin{array}{l}\text { Individuals' } \\
\text { performance } \\
\text { evaluations }\end{array}$ \\
\hline $\begin{array}{l}\text { Somaya, } \\
\text { Williamson, \& } \\
\text { Lorinkova } \\
(2008)\end{array}$ & $\begin{array}{l}\text { How does the mobility of } \\
\text { employees across } \\
\text { different types of firms } \\
\text { (i.e., competitors vs. } \\
\text { cooperators) influences } \\
\text { firm performance? }\end{array}$ & Individual & $\mathrm{S}, \mathrm{O}, \mathrm{M}$ & $\begin{array}{l}\text { Empirical } \\
\text { quantitative }\end{array}$ & $\begin{array}{l}\text { Patent attorney movements } \\
\text { between law firms and } \\
\text { Fortune } 500 \text { companies over } \\
\text { the period 1991-1995 }\end{array}$ & $\begin{array}{l}\text { Losing an employee to or gaining an } \\
\text { employee from a potential cooperator } \\
\text { results in a focal firm getting more } \\
\text { business from that cooperating firm. } \\
\text { However, losing an employee to or } \\
\text { gaining an employee from a potential } \\
\text { competitor results in a focal firm } \\
\text { getting less business from that } \\
\text { cooperating firm. }\end{array}$ & $\begin{array}{l}\text { Volume of patent } \\
\text { business } \\
\text { outsourced by a } \\
\text { particular } \\
\text { company to a } \\
\text { focal law firm }\end{array}$ \\
\hline
\end{tabular}


NETWORK BROKERAGE 82

\begin{tabular}{|c|c|c|c|c|c|c|c|}
\hline Author(s) & Research question(s) & $\begin{array}{c}\text { Level(s) of } \\
\text { analysis }\end{array}$ & $\begin{array}{c}\text { Categories of } \\
\text { factors }\end{array}$ & $\begin{array}{l}\text { Type of } \\
\text { article }\end{array}$ & Sample & Findings/Conclusions & Outcomes \\
\hline $\begin{array}{l}\text { Spiro, Acton, } \\
\text { \& Butts } \\
(2013)\end{array}$ & $\begin{array}{l}\text { What are relational } \\
\text { sequences that constitute } \\
\text { bridging opportunities in } \\
\text { a dynamic relational } \\
\text { structure? }\end{array}$ & Organization & S, D & $\begin{array}{l}\text { Empirical } \\
\text { quantitative }\end{array}$ & $\begin{array}{l}\text { The emergent multi- } \\
\text { organizational network of } \\
\text { collaboration activity among } \\
\text { organizations involved in the } \\
\text { initial response to Hurricane } \\
\text { Katrina }\end{array}$ & $\begin{array}{l}\text { Three distinct classes of brokerage } \\
\text { behavior in dynamic relational data: } \\
\text { transfer, matchmaking, and } \\
\text { coordination }\end{array}$ & -- \\
\hline $\operatorname{Stam}(2010)$ & $\begin{array}{l}\text { How participation in } \\
\text { industry events (e.g. } \\
\text { conferences) relates to } \\
\text { entrepreneurs' brokerage } \\
\text { positions in informal } \\
\text { industry networks and } \\
\text { how these positions, in } \\
\text { turn, impact new venture } \\
\text { performance. }\end{array}$ & $\begin{array}{l}\text { Individual, } \\
\text { Organization }\end{array}$ & $\mathrm{A}, \mathrm{S}, \mathrm{O}$ & $\begin{array}{l}\text { Empirical } \\
\text { quantitative }\end{array}$ & $\begin{array}{l}\text { Open source software } \\
\text { industry in the Netherlands, } \\
\text { data combined (I) secondary } \\
\text { data on } 45 \text { industry events } \\
\text { that took place during } 1999 \text { - } \\
2004 \text {, (II) survey data } \\
\text { obtained directly from the } \\
102 \text { entrepreneurs from } 75 \\
\text { firms }\end{array}$ & $\begin{array}{l}\text { (1) Entrepreneurs who participated in } \\
\text { heterogeneous events and bridged } \\
\text { between events with few common } \\
\text { participants were more likely to be } \\
\text { brokers. (2) such relationship is } \\
\text { stronger for entrepreneurs with } \\
\text { broader prior career experiences. (3) } \\
\text { network brokerage mediates the } \\
\text { event participation-performance link. }\end{array}$ & $\begin{array}{l}\text { The } \\
\text { entrepreneur's } \\
\text { brokerage position } \\
\text { in the industry's } \\
\text { social network } \\
\text { structure and sales } \\
\text { growth }\end{array}$ \\
\hline $\begin{array}{l}\text { Stam \& } \\
\text { Elfring (2008) }\end{array}$ & $\begin{array}{l}\text { How does the social } \\
\text { capital that is embedded } \\
\text { in the intra- and extra- } \\
\text { industry ties of a new } \\
\text { venture's founding team } \\
\text { influence the relationship } \\
\text { between the firm's } \\
\text { entrepreneurial } \\
\text { orientation and its } \\
\text { performance? }\end{array}$ & Organization & $\mathrm{S}, \mathrm{O}, \mathrm{M}$ & $\begin{array}{l}\text { Empirical } \\
\text { quantitative }\end{array}$ & $\begin{array}{l}127 \text { firms in the emerging } \\
\text { open source software } \\
\text { industry in the Netherlands, } \\
2005\end{array}$ & $\begin{array}{l}\text { The relationship between } \\
\text { entrepreneurial orientation and } \\
\text { performance is stronger for firms } \\
\text { with extensive bridging ties. }\end{array}$ & $\begin{array}{l}\text { New venture } \\
\text { performance }\end{array}$ \\
\hline $\begin{array}{l}\text { Stevenson \& } \\
\text { Greenberg } \\
(2000)\end{array}$ & $\begin{array}{l}\text { What explains the } \\
\text { success and failure of } \\
\text { actors in a network of } \\
\text { relationships trying to } \\
\text { influence policies on } \\
\text { environmental issues in a } \\
\text { small city? }\end{array}$ & Organization & $\mathrm{A}, \mathrm{B}, \mathrm{O}$ & $\begin{array}{l}\text { Empirical } \\
\text { quantitative }\end{array}$ & $\begin{array}{l}\text { Study of multiple } \\
\text { environmental policy issues } \\
\text { that arose in a city west of } \\
\text { Boston with a population of } \\
\text { approximately } 83,000\end{array}$ & $\begin{array}{l}\text { If the political opportunity structure } \\
\text { is perceived as favorable during the } \\
\text { framing process, actors are likely to } \\
\text { use the low-cost direct contact } \\
\text { strategy. When faced with } \\
\text { opposition, however, actors are likely } \\
\text { to use their political contacts as part } \\
\text { of a direct strategy, but they may } \\
\text { supplement their actions with the use } \\
\text { of brokers to bridge differences or } \\
\text { contact sympathetic others. When } \\
\text { faced with opposition and an } \\
\text { indifferent or unfavorable political } \\
\text { opportunity structure, however, the } \\
\text { actors can be expected to resort to } \\
\text { brokers to reach out to the opposition } \\
\text { and to mobilize coalitions of } \\
\text { supporters to sway decision makers. }\end{array}$ & $\begin{array}{l}\text { Success and } \\
\text { failure of actors in } \\
\text { a network of } \\
\text { relationships } \\
\text { trying to influence } \\
\text { policies on } \\
\text { environmental } \\
\text { issues }\end{array}$ \\
\hline
\end{tabular}


NETWORK BROKERAGE 83

\begin{tabular}{|c|c|c|c|c|c|c|c|}
\hline Author(s) & Research question(s) & $\begin{array}{l}\text { Level(s) of } \\
\text { analysis }\end{array}$ & $\begin{array}{c}\text { Categories of } \\
\text { factors }\end{array}$ & $\begin{array}{l}\text { Type of } \\
\text { article }\end{array}$ & Sample & Findings/Conclusions & Outcomes \\
\hline $\begin{array}{l}\text { Stovel \& } \\
\text { Shaw (2012) }\end{array}$ & $\begin{array}{l}\text { Why is brokerage } \\
\text { important? What is a } \\
\text { broker? }\end{array}$ & Individual & $\mathrm{A}, \mathrm{S}, \mathrm{B}, \mathrm{O}$ & Conceptual & - & $\begin{array}{l}\text { Informal relationships play a crucial } \\
\text { role in connecting temporally, } \\
\text { geographically, or socially disparate } \\
\text { segments of a population. Brokers } \\
\text { often benefit from being in the } \\
\text { middle of otherwise unconnected } \\
\text { actors. The benefits brokers enjoy } \\
\text { can take the form of money, } \\
\text { information, access to opportunities, } \\
\text { enhanced status, or ill-defined claims } \\
\text { on side parties' loyalty. The } \\
\text { prevalence and character of } \\
\text { brokerage is closely connected to the } \\
\text { macro-level structure of a time or } \\
\text { place. }\end{array}$ & Performance \\
\hline $\begin{array}{l}\text { Stuart, } \\
\text { Ozdemir, \& } \\
\text { Ding (2007) }\end{array}$ & $\begin{array}{l}\text { (1) How do extensive, } \\
\text { formal interactions } \\
\text { between biotechnology } \\
\text { firms and universities } \\
\text { influence the dynamics } \\
\text { of downstream alliance } \\
\text { activity in the industry? } \\
\text { (2) What extent is the } \\
\text { propensity to in-source } \\
\text { university science a } \\
\text { function of the within- } \\
\text { academic networks of the } \\
\text { founders and scientific } \\
\text { advisors of the } \\
\text { biotechnology firms? }\end{array}$ & $\begin{array}{l}\text { Individual, } \\
\text { Inter- } \\
\text { organization }\end{array}$ & $\mathrm{S}, \mathrm{O}, \mathrm{M}, \mathrm{D}$ & $\begin{array}{l}\text { Empirical } \\
\text { quantitative }\end{array}$ & $\begin{array}{l}429 \text { U.S.-headquartered } \\
\text { biotechnology firms that } \\
\text { have issued shares to the } \\
\text { public, 1972-2002 }\end{array}$ & $\begin{array}{l}\text { Firms with multiple in-licensing } \\
\text { agreements are more likely to attract } \\
\text { revenue-generating alliances with } \\
\text { downstream partners. The positive } \\
\text { relationship between in-licenses and } \\
\text { downstream alliances attenuates as } \\
\text { firms mature. The diversity and the } \\
\text { quality of the academic connections } \\
\text { of firms' principals influences their } \\
\text { chances of successfully acquiring } \\
\text { commercialization rights to scientific } \\
\text { discoveries in universities. }\end{array}$ & Alliances \\
\hline $\begin{array}{l}\text { Sullivan, } \\
\text { Tang, \& } \\
\text { Marquis } \\
(2014)\end{array}$ & $\begin{array}{l}\text { How does small-world } \\
\text { network imprint affect } \\
\text { subsequent firm } \\
\text { learning? }\end{array}$ & $\begin{array}{l}\text { Inter- } \\
\text { organization }\end{array}$ & $\mathrm{S}, \mathrm{O}, \mathrm{M}, \mathrm{D}$ & $\begin{array}{l}\text { Empirical } \\
\text { quantitative }\end{array}$ & $\begin{array}{l}\text { US venture capital firms } \\
\text { from } 1995 \text { to } 2003\end{array}$ & $\begin{array}{l}\text { Firms embedded in networks having } \\
\text { denser clustering and shorter path } \\
\text { lengths at founding are subsequently } \\
\text { more inclined toward exploratory } \\
\text { learning. We also demonstrate that } \\
\text { subsequent network positions } \\
\text { (closeness centrality and structural } \\
\text { holes) strengthen the initial small } \\
\text { world network imprinting effect. }\end{array}$ & $\begin{array}{l}\text { The exploratory } \\
\text { learning of VC } \\
\text { firms }\end{array}$ \\
\hline
\end{tabular}


NETWORK BROKERAGE 84

\begin{tabular}{|c|c|c|c|c|c|c|c|}
\hline Author(s) & Research question(s) & $\begin{array}{l}\text { Level(s) of } \\
\text { analysis }\end{array}$ & $\begin{array}{c}\text { Categories of } \\
\text { factors }\end{array}$ & $\begin{array}{l}\text { Type of } \\
\text { article }\end{array}$ & Sample & Findings/Conclusions & Outcomes \\
\hline $\begin{array}{l}\text { Sytch \& } \\
\text { Tatarynowicz } \\
(2014)\end{array}$ & $\begin{array}{l}\text { What are the } \\
\text { evolutionary dynamics of } \\
\text { a dual social structure } \\
\text { encompassing } \\
\text { collaboration and conflict } \\
\text { among corporate actors? }\end{array}$ & Organization & $\mathrm{S}, \mathrm{B}, \mathrm{O}, \mathrm{D}$ & $\begin{array}{l}\text { Empirical } \\
\text { quantitative }\end{array}$ & $\begin{array}{l}\text { Interorganizational } \\
\text { partnerships and on patent } \\
\text { infringement and antitrust } \\
\text { lawsuits among firms in the } \\
\text { global pharmaceutical and } \\
\text { biotechnology industry } \\
\text { between } 1996 \text { and } 2006 \text {. }\end{array}$ & $\begin{array}{l}\text { Existing collaborative or conflictual } \\
\text { relationships between two companies } \\
\text { engender future relationships of the } \\
\text { same type, but crowd out } \\
\text { relationships of the different type. }\end{array}$ & $\begin{array}{l}\text { The Formation of } \\
\text { New } \\
\text { Collaborative and } \\
\text { Conflictual Ties } \\
\text { by Firms }\end{array}$ \\
\hline Tasselli (2015) & $\begin{array}{l}\text { How does the structure of } \\
\text { professionals' networks } \\
\text { relate to inter- } \\
\text { professional knowledge } \\
\text { transfer in organizations? } \\
\text { And how do individual } \\
\text { characteristics of } \\
\text { professionals combine } \\
\text { with network structure in } \\
\text { explaining knowledge } \\
\text { transfer patterns? }\end{array}$ & Individual & $\mathrm{S}, \mathrm{O}, \mathrm{M}$ & $\begin{array}{l}\text { Empirical } \\
\text { mixed } \\
\text { methods }\end{array}$ & $\begin{array}{l}\text { Informal network of } 1,036 \\
\text { knowledge transfer ties } \\
\text { among } 118 \text { professionals ( } 53 \\
\text { doctors and } 65 \text { nurses) } \\
\text { through a sociometric survey } \\
\text { and qualitative data from } 21 \\
\text { semi-structured interviews }\end{array}$ & $\begin{array}{l}\text { Junior doctors and nurse managers, } \\
\text { are more likely to gain access to non- } \\
\text { redundant, valuable knowledge } \\
\text { through brokerage. }\end{array}$ & $\begin{array}{l}\text { Inter-professional } \\
\text { knowledge } \\
\text { transfer }\end{array}$ \\
\hline $\begin{array}{l}\text { Tasselli \& } \\
\text { Kilduff (2018) }\end{array}$ & $\begin{array}{l}\text { Does personality affect } \\
\text { whether Simmelian } \\
\text { brokers are trusted by } \\
\text { their friends? }\end{array}$ & Individual & $\mathrm{S}, \mathrm{O}, \mathrm{M}$ & $\begin{array}{l}\text { Empirical } \\
\text { quantitative }\end{array}$ & $\begin{array}{l}148 \text { members of a full-time, } \\
\text { two-year European business } \\
\text { school master's degree } \\
\text { program; } 84 \text { professionals } \\
\text { employed in a critical-care } \\
\text { unit of a publicly funded } \\
\text { European hospital }\end{array}$ & $\begin{array}{l}\text { Simmelian brokers are trusted by } \\
\text { their friends if they exhibit a role } \\
\text { appropriate diplomatic personality } \\
\text { style involving flexibility of self- } \\
\text { presentation (high self-monitoring) } \\
\text { and inhibition of verbal } \\
\text { loquaciousness (low blirtatiousness). } \\
\text { For nonbrokers, the most appropriate } \\
\text { trait combination likely to maintain } \\
\text { the trust of a group of tightly bound } \\
\text { colleagues involved a forthright, be- } \\
\text { true-to-yourself, loquacious } \\
\text { personality style (i.e., low self- } \\
\text { monitoring, high blirtatiousness). }\end{array}$ & $\begin{array}{l}\text { The extent of } \\
\text { affect-based trust } \\
\text { from one person } \\
\text { (the rater) to } \\
\text { another (the ratee) }\end{array}$ \\
\hline $\begin{array}{l}\text { Ter Wal, } \\
\text { Alexy, Block, } \\
\text { \& Sandner } \\
\text { (2016) }\end{array}$ & $\begin{array}{l}\text { How do network actors } \\
\text { can access diverse } \\
\text { information that they can } \\
\text { also effectively interpret? }\end{array}$ & Organization & $\mathrm{S}, \mathrm{O}, \mathrm{M}$ & $\begin{array}{l}\text { Empirical } \\
\text { quantitative }\end{array}$ & $\begin{array}{l}\text { CrunchBase data on early- } \\
\text { stage venture capital } \\
\text { investments in the U.S. } \\
\text { information technology } \\
\text { sector }\end{array}$ & $\begin{array}{l}\text { Ventures have the highest chances of } \\
\text { success if their syndicating investors } \\
\text { have either open-specialized or } \\
\text { closed-diverse networks. }\end{array}$ & $\begin{array}{l}\text { Venture success } \\
\text { (the venture's } \\
\text { ability to attract a } \\
\text { second round of } \\
\text { funding) }\end{array}$ \\
\hline Tiwana (2008) & $\begin{array}{l}\text { Do strong ties } \\
\text { complement bridging } \\
\text { ties? }\end{array}$ & Organization & $\mathrm{S}, \mathrm{O}, \mathrm{M}$ & $\begin{array}{l}\text { Empirical } \\
\text { quantitative }\end{array}$ & $\begin{array}{l}42 \text { innovation-seeking } \\
\text { project alliances involving a } \\
\text { major American services } \\
\text { conglomerate and its alliance } \\
\text { partners }\end{array}$ & $\begin{array}{l}\text { Bridging ties are negatively related to } \\
\text { knowledge integration in innovation } \\
\text { seeking project alliances. Strong ties } \\
\text { complement bridging ties in } \\
\text { enhancing knowledge integration in } \\
\text { innovation-seeking project alliances. }\end{array}$ & $\begin{array}{l}\text { Knowledge } \\
\text { integration and } \\
\text { alliance } \\
\text { ambidexterity }\end{array}$ \\
\hline
\end{tabular}


NETWORK BROKERAGE 85

\begin{tabular}{|c|c|c|c|c|c|c|c|}
\hline Author(s) & Research question(s) & $\begin{array}{l}\text { Level(s) of } \\
\text { analysis }\end{array}$ & $\begin{array}{c}\text { Categories of } \\
\text { factors } 4\end{array}$ & $\begin{array}{l}\text { Type of } \\
\text { article }\end{array}$ & Sample & Findings/Conclusions & Outcomes \\
\hline $\begin{array}{l}\text { Tortoriello } \\
\text { (2015) }\end{array}$ & $\begin{array}{l}\text { What are the social } \\
\text { structural conditions } \\
\text { conducive to individuals } \\
\text { supporting, facilitating, } \\
\text { and promoting the } \\
\text { innovativeness of their } \\
\text { colleagues? }\end{array}$ & Individual & $\mathrm{S}, \mathrm{O}$ & $\begin{array}{l}\text { Empirical } \\
\text { quantitative }\end{array}$ & $\begin{array}{l}276 \text { scientists, researchers, } \\
\text { and engineers in the R\&D } \\
\text { division of a large, } \\
\text { multinational high-tech } \\
\text { company. }\end{array}$ & $\begin{array}{l}\text { Embeddedness in a diverse } \\
\text { knowledge clique is positively } \\
\text { related to being a catalyst of } \\
\text { innovation. }\end{array}$ & $\begin{array}{l}\text { The number of } \\
\text { patents }\end{array}$ \\
\hline $\begin{array}{l}\text { Tortoriello \& } \\
\text { Krackhardt } \\
(2010)\end{array}$ & $\begin{array}{l}\text { Under which conditions } \\
\text { are bridging ties } \\
\text { conducive to the } \\
\text { generation of } \\
\text { innovations? }\end{array}$ & $\begin{array}{l}\text { Intra- } \\
\text { organization }\end{array}$ & $\mathrm{S}, \mathrm{O}, \mathrm{M}$ & $\begin{array}{l}\text { Empirical } \\
\text { quantitative }\end{array}$ & $\begin{array}{l}276 \text { respondents in the } R \& D \\
\text { division of a large } \\
\text { multinational and } \\
\text { multidivisional high-tech } \\
\text { company }\end{array}$ & $\begin{array}{l}\text { Bridging intra-organizational } \\
\text { boundaries with strong ties and } \\
\text { Simmelian tie is more strongly } \\
\text { associated with the generation of } \\
\text { innovation. }\end{array}$ & Innovation \\
\hline $\begin{array}{l}\text { Tortoriello, } \\
\text { Reagans, \& } \\
\text { McEvily } \\
(2012)\end{array}$ & $\begin{array}{l}\text { What are the drivers of } \\
\text { variation in boundary } \\
\text { spanners' effectiveness? }\end{array}$ & Individual & $\mathrm{S}, \mathrm{O}, \mathrm{M}$ & $\begin{array}{l}\text { Empirical } \\
\text { mixed } \\
\text { methods }\end{array}$ & $\begin{array}{l}\text { Interviews and survey } \\
\text { involving } 276 \text { employees in } \\
\text { an R\&D division of a large } \\
\text { multinational technology } \\
\text { company }\end{array}$ & $\begin{array}{l}\text { Individuals occupying network } \\
\text { positions that cut across } \\
\text { nonredundant stocks of knowledge } \\
\text { and expertise should develop a } \\
\text { greater capacity for knowledge } \\
\text { acquisition, and this capability should } \\
\text { improve their success in cross-unit } \\
\text { knowledge transfer relationships. }\end{array}$ & $\begin{array}{l}\text { Knowledge } \\
\text { Acquisition }\end{array}$ \\
\hline Uzzi (1999) & $\begin{array}{l}\text { How does social } \\
\text { embeddedness affect an } \\
\text { organization's } \\
\text { acquisition and cost of } \\
\text { financial capital in } \\
\text { middle-market banking? }\end{array}$ & Organization & $\mathrm{S}, \mathrm{O}$ & $\begin{array}{l}\text { Empirical } \\
\text { quantitative }\end{array}$ & $\begin{array}{l}\text { Random sample of } 2,300 \\
\text { small firms, U.S. National } \\
\text { Survey of Small Business } \\
\text { Finances, } 1989\end{array}$ & $\begin{array}{l}\text { Firms are more likely to get loans } \\
\text { and to receive lower interest rates on } \\
\text { loans if their network of bank ties has } \\
\text { a mix of embedded ties and arm's- } \\
\text { length ties. }\end{array}$ & $\begin{array}{l}\text { Acquisition and } \\
\text { cost of financing }\end{array}$ \\
\hline $\begin{array}{l}\text { van Wijk, } \\
\text { Stam, Elfring, } \\
\text { Zietsma, \& } \\
\text { den Hond } \\
(2013)\end{array}$ & $\begin{array}{l}\text { How does collaborative } \\
\text { work between activists } \\
\text { and field incumbents } \\
\text { emerge and affect the } \\
\text { organizational field under } \\
\text { challenge? }\end{array}$ & Organization & $\mathrm{S}, \mathrm{B}, \mathrm{O}, \mathrm{D}$ & $\begin{array}{l}\text { Empirical } \\
\text { qualitative }\end{array}$ & $\begin{array}{l}\text { The sustainable tourism } \\
\text { movement in the Dutch } \\
\text { outbound tour operations } \\
\text { field from } 1980 \text { to } 2005\end{array}$ & $\begin{array}{l}\text { Field incumbents' attempts at } \\
\text { movement cooptation can actually } \\
\text { help, rather than constrain, a } \\
\text { movement in impacting the field } \\
\text { when distributed brokerage occurs } \\
\text { and contributes to mutual cooptation } \\
\text { and the confluence of cultural and } \\
\text { relational costructuration between } \\
\text { movement and field. }\end{array}$ & $\begin{array}{l}\text { Collaborative } \\
\text { work }\end{array}$ \\
\hline
\end{tabular}


NETWORK BROKERAGE 86

\begin{tabular}{|c|c|c|c|c|c|c|c|}
\hline Author(s) & Research question(s) & $\begin{array}{l}\text { Level(s) of } \\
\text { analysis }\end{array}$ & $\begin{array}{c}\text { Categories of } \\
\text { factors }\end{array}$ & $\begin{array}{l}\text { Type of } \\
\text { article }\end{array}$ & Sample & Findings/Conclusions & Outcomes \\
\hline $\begin{array}{l}\text { Vanhaverbeke, } \\
\text { Gilsing, } \\
\text { Beerkens, \& } \\
\text { Duysters } \\
\text { (2009) }\end{array}$ & $\begin{array}{l}\text { How does alliance } \\
\text { network redundancy in a } \\
\text { focal firm's ego network } \\
\text { affect its ability to create } \\
\text { new technologies in its } \\
\text { technology core areas } \\
\text { (exploitation) and/or non- } \\
\text { core areas (exploration)? }\end{array}$ & Organization & S, O, D & $\begin{array}{l}\text { Empirical } \\
\text { quantitative }\end{array}$ & $\begin{array}{l}\text { Patent analysis of } 116 \text { public } \\
\text { firms in } 3 \text { industries } \\
\text { (chemicals, motor vehicles, } \\
\text { and pharmaceuticals) } \\
\text { observed over } 12 \text { years }\end{array}$ & $\begin{array}{l}\text { Whereas novelty access is provided } \\
\text { for by non-redundant partners in a } \\
\text { focal firm's alliance network, the } \\
\text { corresponding ability to absorb novel } \\
\text { technology is enhanced by } \\
\text { redundancy in its network. Two types } \\
\text { of redundancy are identified at } \\
\text { individual firm level (ego's } \\
\text { redundancy and component density). } \\
\text { The efficiency of a certain network } \\
\text { structure is also related to the type of } \\
\text { innovation activity that firms } \\
\text { undertake. }\end{array}$ & $\begin{array}{l}\text { Technological } \\
\text { innovation (\# of } \\
\text { patents) }\end{array}$ \\
\hline $\begin{array}{l}\text { Vasudeva, } \\
\text { Zaheer, \& } \\
\text { Hernandez } \\
(2013)\end{array}$ & $\begin{array}{l}\text { how does the institutional } \\
\text { setting get to the heart of } \\
\text { the mechanisms driving } \\
\text { the effects of structural } \\
\text { holes on firm } \\
\text { innovativeness? }\end{array}$ & Organization & $\mathrm{S}, \mathrm{O}, \mathrm{M}$ & $\begin{array}{l}\text { Empirical } \\
\text { quantitative }\end{array}$ & $\begin{array}{l}\text { Cross-border fuel cell } \\
\text { technology alliance networks } \\
\text { involving } 109 \text { firms from } \\
\text { nine countries between } 1981 \\
\text { and } 2001 .\end{array}$ & $\begin{array}{l}\text { Firm spanning structural holes } \\
\text { obtains the greatest innovation } \\
\text { benefits when the broker firm or its } \\
\text { alliance partners are based in highly } \\
\text { corporatist countries, or under certain } \\
\text { combinations of broker and partner } \\
\text { corporatism. }\end{array}$ & $\begin{array}{l}\text { Firm } \\
\text { innovativeness }\end{array}$ \\
\hline $\begin{array}{l}\text { Vedres \& } \\
\text { Stark (2010) }\end{array}$ & $\begin{array}{l}\text { Does structural folding } \\
\text { (i.e., cohesive } \\
\text { groups/networks that } \\
\text { partially overlap) } \\
\text { contribute to business } \\
\text { group performance? }\end{array}$ & Organization & $\mathrm{S}, \mathrm{O}, \mathrm{M}$ & $\begin{array}{l}\text { Empirical } \\
\text { quantitative }\end{array}$ & $\begin{array}{l}\text { Histories of personnel ties } \\
\text { among the largest enterprises } \\
\text { in Hungary, 1987-2001 }\end{array}$ & $\begin{array}{l}\text { Intercohesion is a significant factor } \\
\text { explaining outstanding business- } \\
\text { group performance: firms in business } \\
\text { groups with more structural folds } \\
\text { show higher revenue growth. }\end{array}$ & $\begin{array}{l}\text { Group } \\
\text { performance }\end{array}$ \\
\hline $\begin{array}{l}\text { Verona, } \\
\text { Prandelli, \& } \\
\text { Sawhney } \\
(2006)\end{array}$ & $\begin{array}{l}\text { What is the role that } \\
\text { third-party virtual } \\
\text { knowledge brokers can } \\
\text { play in enhancing a } \\
\text { firm's innovation } \\
\text { process? }\end{array}$ & $\begin{array}{l}\text { Individual, } \\
\text { Organization }\end{array}$ & $\mathrm{S}, \mathrm{O}$ & Conceptual & - & $\begin{array}{l}\text { Knowledge brokerage can play a } \\
\text { major role in virtual environments by } \\
\text { amplifying the network accessed by } \\
\text { any firm that needs market } \\
\text { knowledge for innovation. Mediators } \\
\text { specialized in customer knowledge } \\
\text { absorption can support the firm's } \\
\text { innovation processes by leveraging } \\
\text { virtual environments in a way that } \\
\text { stretches the opportunities available } \\
\text { for the individual firm both in time } \\
\text { and space. }\end{array}$ & $\begin{array}{l}\text { Innovation } \\
\text { process }\end{array}$ \\
\hline
\end{tabular}


NETWORK BROKERAGE 87

\begin{tabular}{|c|c|c|c|c|c|c|c|}
\hline Author(s) & Research question(s) & $\begin{array}{l}\text { Level(s) of } \\
\text { analysis }\end{array}$ & $\begin{array}{l}\text { Categories of } \\
\text { factors }\end{array}$ & $\begin{array}{l}\text { Type of } \\
\text { article }\end{array}$ & Sample & Findings/Conclusions & Outcomes \\
\hline Vissa (2012) & $\begin{array}{l}\text { What are the effects of } \\
\text { entrepreneurs' } \\
\text { interpersonal networking } \\
\text { style on the initiation of } \\
\text { interorganizational } \\
\text { exchange ties? }\end{array}$ & Individual & $\mathrm{B}, \mathrm{D}$ & $\begin{array}{l}\text { Empirical } \\
\text { mixed } \\
\text { methods }\end{array}$ & $\begin{array}{l}\text { Longitudinal design using } \\
\text { data coded from the business } \\
\text { cards of new contacts formed } \\
\text { over a two-month period by } \\
\text { a panel of } 75 \text { Indian } \\
\text { entrepreneurs operating } \\
\text { business-to-business from } 73 \\
\text { ventures }\end{array}$ & $\begin{array}{l}\text { Entrepreneurs using more network- } \\
\text { deepening actions initiate fewer new } \\
\text { economic exchanges, due (in part) to } \\
\text { their increased reliance on referral- } \\
\text { based search, whereas entrepreneurs } \\
\text { using more network-broadening } \\
\text { actions initiate newer economic } \\
\text { exchanges due (in part) to their } \\
\text { decreased reliance on referral-based } \\
\text { search. }\end{array}$ & - \\
\hline $\begin{array}{l}\text { Vissa \& } \\
\text { Chacar (2009) }\end{array}$ & $\begin{array}{l}\text { What is the impact of } \\
\text { entrepreneurial teams' } \\
\text { external networks on } \\
\text { their ventures' } \\
\text { performance? }\end{array}$ & Organization & $\mathrm{S}, \mathrm{O}, \mathrm{M}$ & $\begin{array}{l}\text { Empirical } \\
\text { quantitative }\end{array}$ & $\begin{array}{l}\text { Cross-sectional data from } \\
470 \text { Indian software ventures }\end{array}$ & $\begin{array}{l}\text { Ventures whose entrepreneurial } \\
\text { teams span many structural holes in } \\
\text { their external advice networks } \\
\text { experience higher performance. }\end{array}$ & $\begin{array}{l}\text { Venture } \\
\text { performance }\end{array}$ \\
\hline $\begin{array}{l}\text { Walker, } \\
\text { Kogut, \& } \\
\text { Shan (1997) }\end{array}$ & $\begin{array}{l}\text { Do new relationships } \\
\text { reproduce or change the } \\
\text { inherited network } \\
\text { structure? }\end{array}$ & Organization & $\mathrm{S}$ & $\begin{array}{l}\text { Empirical } \\
\text { quantitative }\end{array}$ & $\begin{array}{l}81 \text { biotech startups, data } \\
\text { from BIOSCAN and a } \\
\text { database developed from the } \\
\text { North Carolina } \\
\text { Biotechnology Center }\end{array}$ & $\begin{array}{l}\text { Social capital theory is the better } \\
\text { predictor of cooperation over time. } \\
\text { Structural hole theory may apply } \\
\text { more to networks of market } \\
\text { transactions than to networks of } \\
\text { cooperative relationships. }\end{array}$ & - \\
\hline $\begin{array}{l}\text { Wanberg, } \\
\text { Kanfer, \& } \\
\text { Banas }(2000)\end{array}$ & $\begin{array}{l}\text { What are the predictors } \\
\text { and outcomes of } \\
\text { networking intensity for } \\
\text { job search? }\end{array}$ & Individual & $\mathrm{B}, \mathrm{O}$ & $\begin{array}{l}\text { Empirical } \\
\text { quantitative }\end{array}$ & $\begin{array}{l}478 \text { unemployed at time } 1 \\
\text { were recruited from } 33 \text { job } \\
\text { service sites in Minnesota }\end{array}$ & $\begin{array}{l}\text { Expending effort in networking } \\
\text { activities is associated with greater } \\
\text { uses of other job-search methods. } \\
\text { Job-search professionals who wish to } \\
\text { teach and encourage networking as a } \\
\text { job-search tool should work on } \\
\text { increasing networking comfort levels } \\
\text { among their clients. Individuals have } \\
\text { a relative advantage if they use } \\
\text { networking more often and more } \\
\text { extensively. }\end{array}$ & $\begin{array}{l}\text { Networking } \\
\text { intensity, job } \\
\text { search intensity } \\
\text { reemployment } \\
\text { outcomes }\end{array}$ \\
\hline
\end{tabular}


NETWORK BROKERAGE 88

\begin{tabular}{|c|c|c|c|c|c|c|c|}
\hline Author(s) & Research question(s) & $\begin{array}{l}\text { Level(s) of } \\
\text { analysis }\end{array}$ & $\begin{array}{c}\text { Categories of } \\
\text { factors }\end{array}$ & $\begin{array}{l}\text { Type of } \\
\text { article }\end{array}$ & Sample & Findings/Conclusions & Outcomes \\
\hline Wang (2015) & $\begin{array}{l}\text { How do skilled return } \\
\text { migrants, as cross-border } \\
\text { brokers, transfer } \\
\text { knowledge about } \\
\text { organizational practices } \\
\text { from abroad to their } \\
\text { home countries? }\end{array}$ & Individual & $\mathrm{S}, \mathrm{B}, \mathrm{O}, \mathrm{M}$ & $\begin{array}{l}\text { Empirical } \\
\text { quantitative }\end{array}$ & $\begin{array}{l}4,183 \text { former J-1 Visa } \\
\text { holders from } 81 \text { countries- } \\
\text { all of whom had worked in } \\
\text { the U.S. }\end{array}$ & $\begin{array}{l}\text { Returnees' knowledge transfer } \\
\text { success depends on their } \\
\text { embeddedness in both their home- } \\
\text { and host country workplaces. The } \\
\text { presence of other returnees in a } \\
\text { home-country workplace decreases } \\
\text { the positive effect of a returnee's } \\
\text { host-country embeddedness, whereas } \\
\text { the similarity of a returnee's industry } \\
\text { background to the home-country } \\
\text { industry increases it. At the country } \\
\text { level, high xenophobia in a given } \\
\text { home country diminishes the positive } \\
\text { effect of host-country embeddedness } \\
\text { but increases the positive effect of } \\
\text { home country embeddedness. }\end{array}$ & $\begin{array}{l}\text { Knowledge } \\
\text { transfer success }\end{array}$ \\
\hline $\begin{array}{l}\text { Wang, Rodan, } \\
\text { Fruin, \& Xu } \\
\text { (2014) }\end{array}$ & $\begin{array}{l}\text { How do knowledge and } \\
\text { social networks influence } \\
\text { where researchers search } \\
\text { for discoveries? }\end{array}$ & Individual & $\mathrm{S}, \mathrm{O}$ & $\begin{array}{l}\text { Empirical } \\
\text { quantitative }\end{array}$ & $\begin{array}{l}1,354 \text { researchers in a } \\
\text { microprocessor manufacturer } \\
\text { in California who filed at } \\
\text { least one patent application } \\
\text { that was eventually granted } \\
\text { between } 1991 \text { and } 1995, \text { and } \\
\text { who remained active in } \\
\text { patenting during the } \\
\text { observation period } 1996- \\
2000\end{array}$ & $\begin{array}{l}\text { A researcher with knowledge } \\
\text { elements rich in structural holes in } \\
\text { the knowledge network tends to } \\
\text { explore fewer new knowledge } \\
\text { elements from outside the firm, } \\
\text { whereas structural holes in the } \\
\text { collaboration network increase } \\
\text { exploratory innovation. }\end{array}$ & $\begin{array}{l}\text { The frequency of } \\
\text { a researcher's } \\
\text { exploratory } \\
\text { innovation }\end{array}$ \\
\hline $\begin{array}{l}\text { Williams \& } \\
\text { Shepherd } \\
(2018)\end{array}$ & $\begin{array}{l}\text { How do actors organize } \\
\text { compassionate responses } \\
\text { to victim suffering? }\end{array}$ & Individual & $\mathrm{S}, \mathrm{O}$ & $\begin{array}{l}\text { Empirical } \\
\text { quantitative }\end{array}$ & $\begin{array}{l}\text { Content analysis of } 143 \\
\text { venture histories created in } \\
\text { the aftermath of the Black } \\
\text { Saturday natural disaster } \\
\text { (Australia) }\end{array}$ & $\begin{array}{l}\text { Actor's brokerage relationships } \\
\text { within and between communities } \\
\text { influence resource mobilization and } \\
\text { compassion outcomes but do so } \\
\text { through divergent paths. }\end{array}$ & $\begin{array}{l}\text { Resource } \\
\text { mobilization and } \\
\text { response } \\
\text { effectiveness }\end{array}$ \\
\hline $\begin{array}{l}\text { Wong \& Boh } \\
(2010)\end{array}$ & $\begin{array}{l}\text { How are third parties' } \\
\text { social network structures } \\
\text { associated with } \\
\text { managers' reputations for } \\
\text { trust worthiness among } \\
\text { their peers? }\end{array}$ & Individual & $\mathrm{S}, \mathrm{O}$ & $\begin{array}{l}\text { Empirical } \\
\text { quantitative }\end{array}$ & $\begin{array}{l}88 \text { directors and } 96 \text { deputy } \\
\text { directors working at a large } \\
\text { emergency response services } \\
\text { firm with approximately } \\
20,000 \text { employees. }\end{array}$ & $\begin{array}{l}\text { A manager's advocate network } \\
\text { attributes such as network } \\
\text { heterogeneity, nonoverlapping } \\
\text { contacts, and network density all play } \\
\text { key roles in enhancing a manager's } \\
\text { peer reputation. }\end{array}$ & $\begin{array}{l}\text { Peer reputations } \\
\text { for } \\
\text { trustworthiness }\end{array}$ \\
\hline $\begin{array}{l}\text { Xia, Wang, } \\
\text { Lin, Yang, \& } \\
\text { Li (2018) }\end{array}$ & $\begin{array}{l}\text { Will firms with varying } \\
\text { network advantages } \\
\text { respond differently to the } \\
\text { market demands of } \\
\text { resource dependence in } \\
\text { their decisions for } \\
\text { alliance formation? }\end{array}$ & Organization & $\mathrm{S}, \mathrm{O}$ & $\begin{array}{l}\text { Empirical } \\
\text { quantitative }\end{array}$ & $\begin{array}{l}735,523 \text { alliance at the firm- } \\
\text { industry-year level during } \\
\text { the period from } 1994 \text { to } 2007 \\
\text { in U.S. computer industry }\end{array}$ & $\begin{array}{l}\text { The skills that a firm develops to } \\
\text { bridge disconnected actors in its } \\
\text { primary industry may be leveraged to } \\
\text { bridge structural holes across } \\
\text { industries. }\end{array}$ & $\begin{array}{l}\text { Joint venture } \\
\text { formation }\end{array}$ \\
\hline
\end{tabular}


NETWORK BROKERAGE 89

\begin{tabular}{|c|c|c|c|c|c|c|c|}
\hline Author(s) & Research question(s) & $\begin{array}{l}\text { Level(s) of } \\
\text { analysis }\end{array}$ & $\begin{array}{c}\text { Categories of } \\
\text { factors }\end{array}$ & $\begin{array}{l}\text { Type of } \\
\text { article }\end{array}$ & Sample & Findings/Conclusions & Outcomes \\
\hline $\begin{array}{l}\text { Xiao \& Tsui } \\
(2007)\end{array}$ & $\begin{array}{l}\text { How do the mechanisms } \\
\text { of social capital operate } \\
\text { in other contexts with } \\
\text { different cultural norms } \\
\text { and market mechanisms? }\end{array}$ & Individual & $\mathrm{S}, \mathrm{O}, \mathrm{M}$ & $\begin{array}{l}\text { Empirical } \\
\text { mixed } \\
\text { methods }\end{array}$ & $\begin{array}{l}435 \text { questionnaires and } \\
\text { interviews from four } \\
\text { companies in China }\end{array}$ & $\begin{array}{l}\text { Integrators who bring people together } \\
\text { to fill structural holes, not brokers, fit } \\
\text { with the collectivistic values of } \\
\text { China. In high-commitment } \\
\text { organizations, the integrators enjoy } \\
\text { greater career benefits than brokers. }\end{array}$ & $\begin{array}{l}\text { Career } \\
\text { performance } \\
\text { (salary, bonus, } \\
\text { and job } \\
\text { satisfaction) }\end{array}$ \\
\hline $\begin{array}{l}\text { Yang, Lin, \& } \\
\text { Peng (2011) }\end{array}$ & $\begin{array}{l}\text { What drives acquisitions } \\
\text { of alliance partners? }\end{array}$ & Organization & $\mathrm{S}, \mathrm{O}, \mathrm{M}$ & $\begin{array}{l}\text { Empirical } \\
\text { quantitative }\end{array}$ & $\begin{array}{l}2963 \text { alliances of } 1453 \text { firms } \\
\text { in the U.S. computer } \\
\text { industry }\end{array}$ & $\begin{array}{l}\text { Joint brokerage occupied by alliance } \\
\text { firms strengthens the positive } \\
\text { relationship between exploration } \\
\text { alliances and subsequent acquisitions } \\
\text { of alliance partners. }\end{array}$ & $\begin{array}{l}\text { Acquisitions of } \\
\text { Alliance Partners }\end{array}$ \\
\hline $\begin{array}{l}\text { Yin, Wu, \& } \\
\text { Tsai (2012) }\end{array}$ & $\begin{array}{l}\text { Whether and when does } \\
\text { the degree of brokerage } \\
\text { persists overtime? }\end{array}$ & Organization & $\mathrm{B}, \mathrm{D}$ & $\begin{array}{l}\text { Empirical } \\
\text { quantitative }\end{array}$ & $\begin{array}{l}129 \text { longitudinal alliance } \\
\text { data collected from } 95 \text { firms } \\
\text { in the aircraft, airline, } \\
\text { chemical, and energy } \\
\text { industries (Database: } g \\
\text { Jupiter Research, } \\
\text { LexisNexis, } \\
\text { http://www.nmm.com } \\
\text { and http://www.pla) }\end{array}$ & $\begin{array}{l}\text { When coordination needs in an } \\
\text { alliance are high, firms with high } \\
\text { prior brokerage are preferred because } \\
\text { of their ability to reach diverse } \\
\text { others. Thus, they can facilitate } \\
\text { coordination and resolve differences } \\
\text { among other partners in the alliance, } \\
\text { retain their influence. }\end{array}$ & - \\
\hline $\begin{array}{l}\text { Youtie \& } \\
\text { Shapira (2008) }\end{array}$ & $\begin{array}{l}\text { How can a university } \\
\text { become a knowledge } \\
\text { hub? }\end{array}$ & $\begin{array}{l}\text { Inter- } \\
\text { organization, } \\
\text { Inter- } \\
\text { community }\end{array}$ & $\mathrm{A}, \mathrm{S}, \mathrm{B}, \mathrm{O}, \mathrm{D}$ & $\begin{array}{l}\text { Empirical } \\
\text { qualitative }\end{array}$ & $\begin{array}{l}\text { Case study of Georgia } \\
\text { Institute of Technology } \\
\text { (Georgia Tech) }\end{array}$ & $\begin{array}{l}\text { Universities have evolved from } \\
\text { knowledge storehouses, and } \\
\text { knowledge factories, into knowledge } \\
\text { hubs. These universities actively } \\
\text { foster knowledge exchange, learning, } \\
\text { and innovation through new methods } \\
\text { and the development of boundary- } \\
\text { spanning activities. Georgia Tech has } \\
\text { become an "animateur" of } \\
\text { development. }\end{array}$ & Innovation hub \\
\hline $\begin{array}{l}\text { Zaheer \& Bell } \\
(2005)\end{array}$ & $\begin{array}{l}\text { How do innovative } \\
\text { capabilities - both those } \\
\text { of focal firms and those } \\
\text { they access through their } \\
\text { networks - influence the } \\
\text { performance of Canadian } \\
\text { mutual fund companies? }\end{array}$ & Organization & $\mathrm{S}, \mathrm{O}$ & $\begin{array}{l}\text { Empirical } \\
\text { quantitative }\end{array}$ & $\begin{array}{l}\text { Fund companies of the } \\
\text { Investment Funds Institute of } \\
\text { Canada (IFIC) as listed in the } \\
\text { January } 1998 \text { Membership } \\
\text { Directory }\end{array}$ & $\begin{array}{l}\text { A firm's innovative capabilities and } \\
\text { its network structure both enhance } \\
\text { firm performance, while the } \\
\text { innovativeness of its contacts does } \\
\text { not do so directly. }\end{array}$ & Market share \\
\hline
\end{tabular}


NETWORK BROKERAGE 90

\begin{tabular}{|c|c|c|c|c|c|c|c|}
\hline Author(s) & Research question(s) & $\begin{array}{l}\text { Level(s) of } \\
\text { analysis }\end{array}$ & $\begin{array}{c}\text { Categories of } \\
\text { factors } 4\end{array}$ & $\begin{array}{l}\text { Type of } \\
\text { article }\end{array}$ & Sample & Findings/Conclusions & Outcomes \\
\hline $\begin{array}{l}\text { Zaheer \& } \\
\text { Soda (2009) }\end{array}$ & $\begin{array}{l}\text { Where do structural } \\
\text { holes, particularly at the } \\
\text { organizational level of } \\
\text { analysis, come from? }\end{array}$ & Team & $\mathrm{A}, \mathrm{S}, \mathrm{O}, \mathrm{M}, \mathrm{D}$ & $\begin{array}{l}\text { Empirical } \\
\text { quantitative }\end{array}$ & $\begin{array}{l}501 \mathrm{TV} \text { productions } \\
\text { produced and broadcast over } \\
\text { a } 12 \text {-year period in Italy }\end{array}$ & $\begin{array}{l}\text { Structural holes spanned by teams } \\
\text { originate from the content } \\
\text { heterogeneity among past alters, the } \\
\text { prior status and centrality of teams } \\
\text { that members were part of in the past, } \\
\text { the lack of the past team cohesion, } \\
\text { and structural holes spanned in the } \\
\text { past. Spanning structural holes and } \\
\text { the homogeneity of current alters' } \\
\text { content is associated with superior } \\
\text { team performance in terms of greater } \\
\text { viewership. }\end{array}$ & $\begin{array}{l}\text { Team } \\
\text { performance }\end{array}$ \\
\hline $\begin{array}{l}\text { Zhelyazkov } \\
\text { (2018) }\end{array}$ & $\begin{array}{l}\text { How do the attitudes and } \\
\text { motivations of the } \\
\text { intermediary that stands } \\
\text { between them play a role } \\
\text { in a triadic closure? }\end{array}$ & Organization & A, B, D & $\begin{array}{l}\text { Empirical } \\
\text { quantitative }\end{array}$ & $\begin{array}{l}\text { Longitudinal dataset of the } \\
\text { investment decisions of } \\
\text { limited partners investing in } \\
\text { U.S. venture capital firms in } \\
\text { the period 1997-2007 }\end{array}$ & $\begin{array}{l}\text { An intermediary is less likely to } \\
\text { facilitate a direct connection under } \\
\text { two conditions: (1) the intermediary } \\
\text { has experienced failed collaborations } \\
\text { with one of the indirectly connected } \\
\text { parties or (2) the intermediary has } \\
\text { competitive concerns-driven by its } \\
\text { replaceability and relative } \\
\text { attractiveness- that it may lose } \\
\text { future business to one of the } \\
\text { indirectly connected parties. }\end{array}$ & - \\
\hline Zheng (2010) & $\begin{array}{l}\text { (1) Are empirical } \\
\text { research findings } \\
\text { consistent with } \\
\text { theoretical hypotheses? } \\
\text { (2) Have scholars } \\
\text { reached a consensus on } \\
\text { the relationship between } \\
\text { social capital and } \\
\text { innovation? (3) What are } \\
\text { the components of social } \\
\text { capital that have } \\
\text { demonstrated impact on } \\
\text { innovation? (4) How are } \\
\text { these components of } \\
\text { social capital related to } \\
\text { innovation? (5) What } \\
\text { factors may modify the } \\
\text { link to innovation? }\end{array}$ & $\begin{array}{l}\text { Individual, } \\
\text { Group, } \\
\text { Organization, } \\
\text { City and } \\
\text { Nations }\end{array}$ & $\mathrm{A}, \mathrm{S}, \mathrm{O}, \mathrm{M}$ & Conceptual & - & $\begin{array}{l}\text { Structural holes tend to bring } \\
\text { beneficial effects for individual } \\
\text { actors, and closure tends to influence } \\
\text { innovation negatively. Knowledge/ } \\
\text { background heterogeneity might } \\
\text { serve as a mediator between } \\
\text { structural holes and innovation. } \\
\text { When teams, organizations, and } \\
\text { cities are the focal units of analysis, } \\
\text { there are more inconsistent findings. }\end{array}$ & Innovation \\
\hline
\end{tabular}


Figure S1

Article Review Methodology for "Network Brokerage” Literature

STEP 1. Search on ISI Web of Science ${ }^{\circledR}$ using the following keywords related to network brokerage:

(*broker* OR "structural hole*" OR "boundary spann*" OR betweenness OR bridg* OR "tertius iungens" OR "tertius gaudens" OR triad* OR refer*) AND *network*

STEP 2. Confine the search to articles published in 58 top- or middle-tier management-related journals

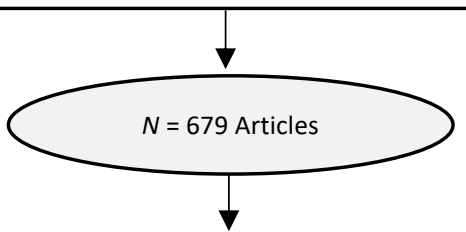

STEP 3. Omit less relevant articles by reviewing titles, keywords, and abstracts according to the six exclusion criteria

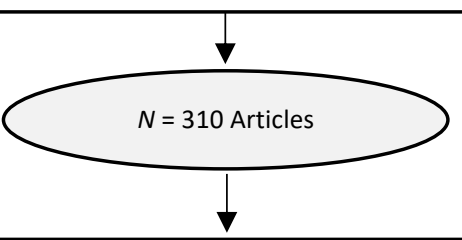

STEP 4. Divide remaining articles into two groups using citations per year from ISI Web of Science ${ }^{\circledR}$ citations index

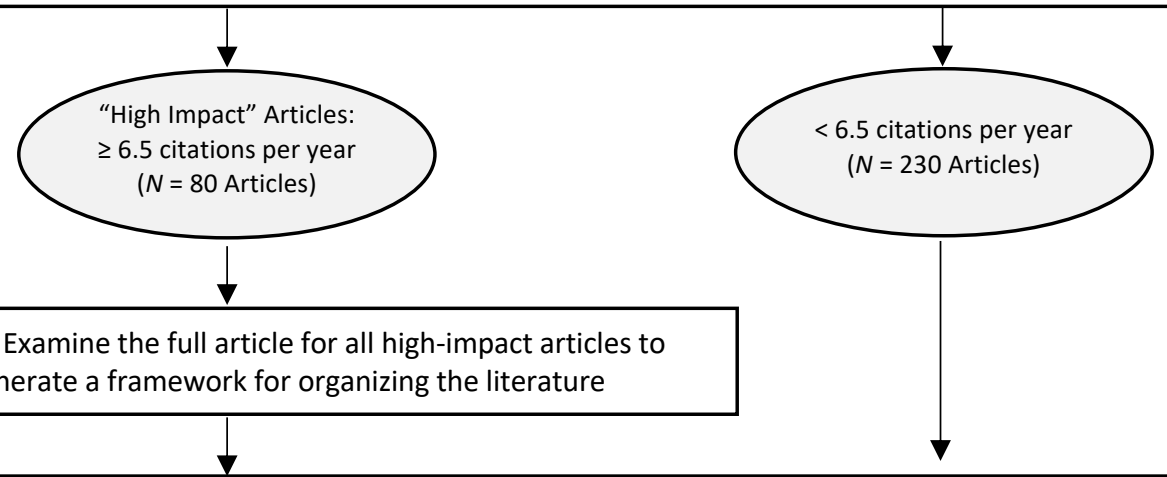

STEP 6. Review and retain additional articles from among the less-cited articles if they offer new insights different from those of the 80 high-impact articles

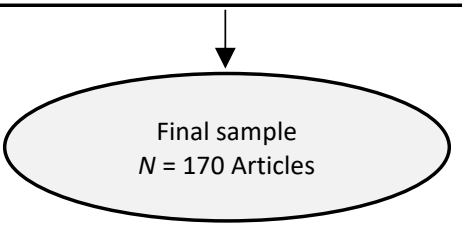




\section{METHODOLOGICAL SUPPLEMENT}

Data for this study were collected from the Institute for Scientific Information (ISI) Web of Science's Social Science Citation Index (SSCI) database. Our review of the network brokerage literature proceeded in six steps (see Figure S1).

In Step 1, we searched the Web of Science database for academic articles containing the term "broker" or other related terms, such as "structural hole", "boundary spanning", "betweenness", "bridging", "tertius iungens", and "tertius gaudens", "triad", or "referral”, in the title, abstract, or keywords..$^{5}$ These keywords were then augmented by wild card suffixes to capture multiple variants of the keywords. Given the wide-ranging scope of these keywords, we then combine the search with another keyword, "network", to restrict our search to relevant articles within our scope. This search using ISI Web of Science (Social Sciences Citation Index) yielded 6,481 matches.

In $\underline{\text { Step } 2}$, to further reduce this population to articles relevant to our focus, we narrowed the search to the results published in major organizational and management journals, reasoning that this would allow us to focus on relevance to the field of management as well as a high quality due to the rigorous peer-review process. We compiled an initial list of 24 top-tier journals in management or related fields like sociology as well as the top specialty journal in this domain, Social Networks, based on published rankings (e.g., Financial Times 50) and impact factors. To supplement our initial list of 24 top journals, we then expanded our search to include top- and middle-tier journals as determined by key business school associations or government agencies in the UK, EU, and Australia. (The U.S. business school accreditation organization, AACSB, does not rank journals but does direct visitors on its website to the journal rankings compiled by Harzing.com.) We used Harzing.com's categorizations of

\footnotetext{
${ }^{5}$ Our search terms were broadly consistent with those used by Long, Cunningham, and Braithwaite (2013) in their small review ( $N=24$ articles) in a specialty health care journal on the topic of network brokerage. Tertius gaudens refers to a brokerage strategy to keep alters apart, and tertius iungens, a brokerage strategy to join alters together. Refer* was used to catch referral-related terms.
} 
management journals to include only those in the areas of General \& Strategy or in Organization Behavior/Studies, Human Resource Management, Industrial Relations. Specifically, we selected journals in these categories that were ranked as $4^{*}, 4$, or 3 (but not 2 or 1) on the UK's Association of Business Schools Academic Journal Quality Guide (Mar 2018) and that were ranked as A or B (but not C) on the European Commission's High Council for Evaluation of Research and Higher Education (Jan 2018) and that were ranked as A* or A (but not B or C) on the Australian Business Deans Council Journal Rankings List (Sep 2016). This yielded 50 journals, 13 of which we had already included previously and 3 of which were practitioner oriented that we did not include (e.g., Harvard Business Review), yielding 34 additional scholarly journals. The search using the combined list of 58 journals ${ }^{6}$ yielded 679 articles in total.

Step 3 involved analyzing the 679 articles to determine how central the brokerage concept was to the paper's substantive arguments. Titles, keywords, and abstracts of the 679 articles were examined by three authors on our research team to determine each article's relevance using the following six exclusion criteria:

1. Articles that did not focus explicitly and specifically on the concept of network

\footnotetext{
6 "Academy of Management Annals", "Academy of Management Journal", "Academy of Management Review", "Administrative Science Quarterly", "American Journal of Sociology", "American Sociological Review", "Annual Review of Sociology", "British Journal of Industrial Relations", "British Journal of Management", "Business Ethics Quarterly", "Entrepreneurship Theory and Practice", "European Journal of Industrial Relations", "Family Business Review", "Business \& Society", "Gender, Work and Organization", "Global Strategy Journal", "Group \& Organization Management", "Human Performance", "Human Relations", "Human Resource Management Journal", "Human Resource Management Review", "Human Resource Management", "Industrial \& Labor Relations Review", "Industrial Relations", "International Journal of Human Resource Management", "International Journal of Industrial Organization", "International Journal of Management Reviews", "Journal of Applied Psychology", "Journal of Business Ethics", "Journal of Business Venturing", "Journal of Human Resources", "Journal of International Business Studies", "Journal of Management Inquiry", "Journal of Management Studies", "Journal of Management", "Journal of Occupational And Organizational Psychology", "Journal of Organizational Behavior", "Journal of Vocational Behavior", "Leadership Quarterly", "Long Range Planning", "Management Learning", "Management Science", "Organization Science", "Organization Studies", "Organization", "Organizational Behavior And Human Decision Processes", "Organizational Research Methods", "Personnel Psychology", "Research in Organizational Behavior", "Research Policy", "Social Forces", "Social Networks", "Strategic Entrepreneurship Journal", "Strategic Management Journal", "Strategic Organization", "Work \& Stress", "Work and Occupations", and "Work, Employment and Society".
} 
brokerage, i.e., where the brokerage concept was only tangentially or indirectly relevant to the paper's central arguments (e.g., we excluded Chataway, Hanlin, Mugwagwa, and Muraguri (2010) for this reason),

2. Articles treating networks as a collection of independent dyads or pairs, neglecting third-party influence on such dyads (e.g., we excluded Seabright, Levinthal, and Fichman (1992) for this reason)

3. Articles focusing on brokers as an occupation rather than a broker as a network intermediary (e.g., we excluded Kellard, Millo, Simon, and Engel (2017) for this reason),

4. Articles focusing on methodological and measurement issues, rather than conceptual contributions (e.g., we excluded Brandes (2008) for this reason),

5. Articles focusing on non-human social networks (e.g. animal societies, molecular systems) or computer simulations of human networks (e.g., we excluded Faust (2010) for this reason),

6. Articles focusing on social networks outside of a work or professional context, such as students, children, families, friends, or local community members (e.g., we excluded Frank, Muller, and Mueller (2013) for this reason).

We ended with 310 relevant articles.

In $\underline{\text { Step } 4}$, we divided the remaining 310 articles into two groups in terms of how impactful they have been to the field by using the citation per year index from ISI Web of Science. Using the mean rate of citations per year in the social sciences, which is 6.5 citations per year, we assigned each article to a "high impact" group if it has at least 6.5 citations per year on average. If an article has less than 6.5 citations per year on average, we put it in a lower-impact group. Following this cutoff, 80 articles out of 310 received 6.5 or more citations per year, while 230 articles received less than 6.5 citations per year. 
In $\underline{\text { Step 5, }}$ two authors on our research team read and coded all of the high-impact articles in depth, categorizing them using 20 dimensions $^{7}$ (some of which are included in Table S1), and created a tentative framework for organizing the network brokerage literature (see Figure 1 in the article).

In $\underline{\text { Step } 6}$, we cycled back to review the 230 lower-impact articles. If any of these articles contain new conceptual and theoretical mechanisms or ideas that were not already captured from the high-impact articles, they will be retained for the final sample along with the highimpact articles. We read the remaining 230 articles - to ensure the completeness and rigor of our review — but only formally retained for the review those that actually add new conceptual and theoretical mechanisms or ideas above and beyond what is already covered by the 80 highimpact articles. This step led us to code and include further 90 articles. Therefore the final population for our review is composed of 170 articles. A detailed description of these articles is included in Table S1.

\footnotetext{
${ }^{7}$ The 20 dimensions include: Author(s), Title, Journal, Year, Research Question(s), Type of Article, Methodology, Sample, Brokerage Definition, Findings, Pattern of Dimensions, Brokerage Antecedents, Brokerage Structure, Brokering Behavior, Brokerage Dynamics, Brokerage Outcomes, Brokerage Moderators, Brokerage Contextual Factors, Highlights, and Notes.
} 


\section{REFERENCES}

Afuah, A. 2013. Are network effects really all about size? The role of structure and conduct. Strategic Management Journal, 34(3): 257-273.

Ahuja, G. 2000. Collaboration networks, structural holes, and innovation: A longitudinal study. Administrative Science Quarterly, 45(3): 425-455.

Ahuja, G., Soda, G., \& Zaheer, A. 2012. Introduction to the special issue: The genesis and dynamics of organizational networks. Organization Science, 23(2): 434-448.

Aldrich, H. E., \& Kim, P. H. 2007. Small worlds, infinite possibilities? How social networks affect entrepreneurial team formation and search. Strategic Entrepreneurship Journal, 1(1-2): 147-165.

Aral, S., \& Van Alstyne, M. 2011. The diversity-bandwidth trade-off. American Journal of Sociology, 117(1): 90-171.

Baer, M. 2010. The strength-of-weak-ties perspective on creativity: A comprehensive examination and extension. Journal of Applied Psychology, 95(3): 592-601.

Balachandran, S., \& Hernandez, E. 2018. Networks and innovation: Accounting for structural and institutional sources of recombination in brokerage triads. Organization Science, 29(1): 80-99.

Baldassarri, D., \& Diani, M. 2007. The integrative power of civic networks. American Journal of Sociology, 113(3): 735-780.

Barnes, M., Kalberg, K., Pan, M., \& Leung, P. 2016. When is brokerage negatively associated with economic benefits? Ethnic diversity, competition, and common-pool resources. Social Networks, 45: 55-65.

Batjargal, B. 2010. The effects of network's structural holes: Polycentric institutions, product portfolio, and new venture growth in China and Russia. Strategic Entrepreneurship Journal, 4(2): 146-163.

Batjargal, B., Hitt, M. A., Tsui, A. S., Arregle, J. L., Webb, J. W., \& Miller, T. L. 2013. Institutional polycentrism, entrepreneurs' social networks, and new venture growth. Academy of Management Journal, 56(4): 1024-1049.

Battilana, J., \& Casciaro, T. 2012. Change agents, networks, and institutions: A contingency theory of organizational change. Academy of Management Journal, 55(2): 381-398.

Baum, J. A. C., McEvily, B., \& Rowley, T. J. 2012. Better with age? Tie longevity and the performance implications of bridging and closure. Organization Science, 23(2): 529-546.

Bessant, J., \& Rush, H. 1995. Building bridges for innovation: The role of consultants in technology transfer. Research Policy, 24(1): 97-114.

Bian, Y. J. 1997. Bringing strong ties back in: Indirect ties, network bridges, and job searches in China. American Sociological Review, 62(3): 366-385.

Bessant, J., \& Rush, H. 1995. Building bridges for innovation: The role of consultants in technology transfer. Research Policy, 24(1): 97-114.

Bidwell, M., \& Fernandez-Mateo, I. 2010. Relationship duration and returns to brokerage in the staffing sector. Organization Science, 21(6): 1141-1158.

Bizzi, L. 2013. The dark side of structural holes: A multilevel investigation. Journal of Management, 39(6): 1554-1578.

Blyler, M., \& Coff, R. W. 2003. Dynamic capabilities, social capital, and rent appropriation: Ties that split pies. Strategic Management Journal, 24(7): 677-686.

Boari, C., \& Riboldazzi, F. 2014. How knowledge brokers emerge and evolve: The role of actors' behaviour. Research Policy, 43(4): 683-695.

Borgatti, S. P., \& Halgin, D. S. 2011. On network theory. Organization Science, 22(5): 1168-1181. 
Brands, R. A., \& Kilduff, M. 2014. Just like a woman? Effects of gender-biased perceptions of friendship network brokerage on attributions and performance. Organization Science, 25(5): 1530-1548.

Brandes, U. 2008. On variants of shortest-path betweenness centrality and their generic computation. Social Networks, 30(2): 136-145.

Brass, D. J., Butterfield, K. D., \& Skaggs, B. C. 1998. Relationships and unethical behavior: A social network perspective. Academy of Management Review, 23(1): 14-31.

Briscoe, F., \& Rogan, M. 2016. Coordinating complex work: Knowledge networks, partner departures, and client relationship performance in a law firm. Management Science, 62(8): 2392-2411.

Briscoe, F., \& Tsai, W. P. 2011. Overcoming relational inertia: How organizational members respond to acquisition events in a law firm. Administrative Science Quarterly, 56(3): 408440.

Burt, R. S. 1997. The contingent value of social capital. Administrative Science Quarterly, 42(2): 339-365.

Burt, R. S. 2000. The network structure of social capital. In R. I. Sutton and B. M. Staw (Eds.), Research in Organizational Behavior: 345-423: JAI Press.

Burt, R. S. 2002. Bridge decay. Social Networks, 24(4): 333-363.

Burt, R. S. 2004. Structural holes and good ideas. American Journal of Sociology, 110(2): 349399.

Burt, R. S. 2007. Secondhand brokerage: Evidence on the importance of local structure for managers, bankers, and analysts. Academy of Management Journal, 50(1): 119-148.

Burt, R. S. 2012. Network-related personality and the agency question: Multirole evidence from a virtual world. American Journal of Sociology, 118(3): 543-591.

Burt, R. S. 2015. Reinforced structural holes. Social Networks, 43: 149-161.

Burt, R. S., Hogarth, R. M., \& Michaud, C. 2000. The social capital of French and American managers. Organization Science, 11(2): 123-147.

Carnabuci, G., \& Dioszegi, B. 2015. Social networks, cognitive style, and innovative performance: A contingency perspective. Academy of Management Journal, 58(3): 881905.

Castilla, E. J. 2005. Social networks and employee performance in a call center. American Journal of Sociology, 110(5): 1243-1283.

Chandler, D., Haunschild, P. R., Rhee, M., \& Beckman, C. M. 2013. The effects of firm reputation and status on interorganizational network structure. Strategic Organization, 11(3): 217-244.

Chataway, J., Hanlin, R., Mugwagwa, J., \& Muraguri, L. 2010. Global health social technologies: Reflections on evolving theories and landscapes. Research Policy, 39(10): 1277-1288.

Clement, J., Shipilov, A. V., \& Galunic, C. 2018. Brokerage as a public good: The externalities of network hubs for different formal roles in creative organizations. Administrative Science Quarterly, 63(2): 251-286.

Collins-Dogrul, J. 2012. Tertius iungens brokerage and transnational intersectoral cooperation. Organization Studies, 33(8): 989-1014.

Cummings, J. N., \& Cross, R. 2003. Structural properties of work groups and their consequences for performance. Social Networks, 25(3): 197-210.

Currie, G., \& White, L. 2012. Inter-professional barriers and knowledge brokering in an organizational context: The case of healthcare. Organization Studies, 33(10): 1333-1361. 
Dahlander, L., \& Wallin, M. W. 2006. A man on the inside: Unlocking communities as complementary assets. Research Policy, 35(8): 1243-1259.

Davis, J. P. 2016. The group dynamics of interorganizational relationships: Collaborating with multiple partners in innovation ecosystems. Administrative Science Quarterly, 61(4): 621-661.

Davis, J. P., \& Eisenhardt, K. M. 2011. Rotating leadership and collaborative innovation: Recombination processes in symbiotic relationships. Administrative Science Quarterly, 56(2): 159-201.

de Vaan, M., Stark, D., \& Vedres, B. 2015. Game changer: The topology of creativity. American Journal of Sociology, 120(4): 1144-1194.

Ebbers, J. J. 2014. Networking behavior and contracting relationships among entrepreneurs in business incubators. Entrepreneurship Theory and Practice, 38(5): 1159-1181.

Fang, R. L., Chi, L., Chen, M. L., \& Baron, R. A. 2015. Bringing political skill into social networks: Findings from a field study of entrepreneurs. Journal of Management Studies, 52(2): $175-212$.

Faust, K. 2010. A puzzle concerning triads in social networks: Graph constraints and the triad census. Social Networks, 32(3): 221-233.

Fernandez, R. M., Castilla, E. J., \& Moore, P. 2000. Social capital at work: Networks and employment at a phone center. American Journal of Sociology, 105(5): 1288-1356.

Fernandez, R. M., \& Gould, R. V. 1994. A dilemma of state power: Brokerage and influence in the national-health policy domain. American Journal of Sociology, 99(6): 1455-1491.

Fernandez-Mateo, I. 2007. Who pays the price of brokerage? Transferring constraint through price setting in the staffing sector. American Sociological Review, 72(2): 291-317.

Fleming, L., Mingo, S., \& Chen, D. 2007. Collaborative brokerage, generative creativity, and creative success. Administrative Science Quarterly, 52(3): 443-475.

Fleming, L., \& Waguespack, D. M. 2007. Brokerage, boundary spanning, and leadership in open innovation communities. Organization Science, 18(2): 165-180.

Floyd, S. W., \& Wooldridge, B. 1997. Middle management's strategic influence and organizational performance. Journal of Management Studies, 34(3): 465-485.

Flynn, F. J., \& Wiltermuth, S. S. 2010. Who's with me? False consensus, brokerage, and ethical decision making in organizations. Academy of Management Journal, 53(5): 1074-1089.

Frank, K. A., Muller, C., \& Mueller, A. S. 2013. The embeddedness of adolescent friendship nominations: The formation of social capital in emergent network structures. American Journal of Sociology, 119(1): 216-253.

Friedman, R. A., \& Podolny, J. 1992. Differentiation of boundary spanning roles: Labor negotiations and implications for role-conflict. Administrative Science Quarterly, 37(1): 28-47.

Galunic, C., Ertug, G., \& Gargiulo, M. 2012. The positive externalities of social capital: Benefiting from senior brokers. Academy of Management Journal, 55(5): 1213-1231.

Gargiulo, M., \& Benassi, M. 2000. Trapped in your own net? Network cohesion, structural holes, and the adaptation of social capital. Organization Science, 11(2): 183-196.

Gargiulo, M., Ertug, G., \& Galunic, C. 2009. The two faces of control: Network closure and individual performance among knowledge workers. Administrative Science Quarterly, 54(2): 299-333.

Giudici, A., Reinmoeller, P., \& Ravasi, D. 2018. Open-system orchestration as a relational source of sensing capabilities: evidence from a venture association. Academy of Management Journal, 61(4): 1369-1402. 
Goldberg, A., Srivastava, S. B., Manian, V. G., Monroe, W., \& Potts, C. 2016. Fitting in or standing out? The tradeoffs of structural and cultural embeddedness. American Sociological Review, 81(6): 1190-1222.

Grosser, T. J., Obstfeld, D., Choi, E. W., Woehler, M., Lopez-Kidwell, V., Labianca, G., \& Borgatti, S. P. 2018. A sociopolitical perspective on employee innovativeness and job performance: The role of political skill and network structure. Organization Science, 29(4): 612-632.

Guan, J. C., \& Liu, N. 2016. Exploitative and exploratory innovations in knowledge network and collaboration network: A patent analysis in the technological field of nano-energy. Research Policy, 45(1): 97-112.

Guan, J. C., Zhang, J. J., \& Yan, Y. 2015. The impact of multilevel networks on innovation. Research Policy, 44(3): 545-559.

Gulati, R., Sytch, M., \& Tatarynowicz, A. 2012. The rise and fall of small worlds: Exploring the dynamics of social structure. Organization Science, 23(2): 449-471.

Guler, I., \& Guillen, M. F. 2010. Home country networks and foreign expansion: Evidence from the venture capital industry. Academy of Management Journal, 53(2): 390-410.

Hahl, O., Kacperczyk, A., \& Davis, J. P. 2016. Knowledge asymmetry and brokerage: Linking network perception to position in structural holes. Strategic Organization, 14(2): 118143.

Hargadon, A. B. 2002. Brokering knowledge: Linking learning and innovation. Research in Organizational Behavior, 24: 41-85.

Hargadon, A. B., \& Sutton, R. I. 1997. Technology brokering and innovation in a product development firm. Administrative Science Quarterly, 42(4): 716-749.

Hite, J. M., \& Hesterly, W. S. 2001. The evolution of firm networks: From emergence to early growth of the firm. Strategic Management Journal, 22(3): 275-286.

Ingram, P., \& Roberts, P. W. 2000. Friendships among competitors in the Sydney hotel industry. American Journal of Sociology, 106(2): 387-423.

Jensen, M. 2008. The use of relational discrimination to manage market entry: When do social status and structural holes work against you? Academy of Management Journal, 51(4): 723-743.

Jonczyk, C. D., Lee, Y. G., Galunic, C. D., \& Bensaou, B. M. 2016. Relational changes during role transitions: The interplay of efficiency and cohesion. Academy of Management Journal, 59(3): 956-982.

Kalish, Y., \& Robins, G. 2006. Psychological predispositions and network structure: The relationship between individual predispositions, structural holes and network closure. Social Networks, 28(1): 56-84.

Kaplan, S., Milde, J., \& Cowan, R. S. 2017. Symbiont practices in boundary spanning: Bridging the cognitive and political divides in interdisciplinary research. Academy of Management Journal, 60(4): 1387-1414.

Kauppila, O. P., Bizzi, L., \& Obstfeld, D. 2018. Connecting and creating: tertius iungens, individual creativity, and strategic decision processes. Strategic Management Journal, 39(3): 697-719.

Kellard, N., Millo, Y., Simon, J., \& Engel, O. 2017. Close communications: Hedge funds, brokers and the emergence of herding. British Journal of Management, 28(1): 84-101.

Kilduff, M., Crossland, C., Tsai, W., \& Krackhardt, D. 2008. Organizational network perceptions versus reality: A small world after all? Organizational Behavior and Human Decision Processes, 107(1): 15-28.

Kirkels, Y., \& Duysters, G. 2010. Brokerage in SME networks. Research Policy, 39(3): 375-385. 
Kleinbaum, A. M. 2012. Organizational misfits and the origins of brokerage in intrafirm networks. Administrative Science Quarterly, 57(3): 407-452.

Kleinbaum, A. M. 2018. Reorganization and tie decay choices. Management Science, 64(5): 1975-2471.

Kleinbaum, A. M., Jordan, A. H., \& Audia, P. G. 2015. An altercentric perspective on the origins of brokerage in social networks: How perceived empathy moderates the self-monitoring effect. Organization Science, 26(4): 1226-1242.

Koka, B. R., \& Prescott, J. E. 2008. Designing alliance networks: The influence of network position, environmental change, and strategy on firm performance. Strategic Management Journal, 29(6): 639-661.

Landis, B., Kilduff, M., Menges, J. I., \& Kilduff, G. J. 2018. The paradox of agency: Feeling powerful reduces brokerage opportunity recognition yet increases willingness to broker. Journal of Applied Psychology, 103(8): 929-938.

Lee, G. K. 2007. The significance of network resources in the race to enter emerging product markets: The convergence of telephony communications and computer networking, 1989-2001. Strategic Management Journal, 28(1): 17-37.

Lee, J. 2010. Heterogeneity, brokerage, and innovative performance: Endogenous formation of collaborative inventor networks. Organization Science, 21(4): 804-822.

Levin, D. Z., Walter, J., Appleyard, M. M., \& Cross, R. 2016. Relational enhancement: How the relational dimension of social capital unlocks the value of network-bridging ties. Group \& Organization Management, 41(4): 415-457.

Li, Y., Li, N., Guo, J., Li, J., \& Harris, T. B. 2018. A network view of advice-giving and individual creativity in teams: A brokerage-driven, socially perpetuated phenomenon. Academy of Management Journal, 61(6): 2210-2229.

Lingo, E. L., \& O'Mahony, S. 2010. Nexus work: Brokerage on creative projects. Administrative Science Quarterly, 55(1): 47-81.

Long, J. C., Cunningham, F. C., \& Braithwaite, J. 2013. Bridges, brokers and boundary spanners in collaborative networks: A systematic review. BMC Health Services Research, 13(158): $1-13$.

Maak, T. 2007. Responsible leadership, stakeholder engagement, and the emergence of social capital. Journal of Business Ethics, 74(4): 329-343.

Madhavan, R., Gnyawali, D. R., \& He, J. Y. 2004. Two's company, three's a crowd? Triads in cooperative-competitive networks. Academy of Management Journal, 47(6): 918-927.

Maguire, S., Hardy, C., \& Lawrence, T. B. 2004. Institutional entrepreneurship in emerging fields: HIV/AIDS treatment advocacy in Canada. Academy of Management Journal, 47(5): 657-679.

Marineau, J. E., Labianca, G., \& Kane, G. C. 2016. Direct and indirect negative ties and individual performance. Social Networks, 44: 238-252.

McDermott, G. A., Corredoira, R. A., \& Kruse, G. 2009. Public-private institutions as catalysts of upgrading in emerging market societies. Academy of Management Journal, 52(6): 1270-1296.

McEvily, B., \& Zaheer, A. 1999. Bridging ties: A source of firm heterogeneity in competitive capabilities. Strategic Management Journal, 20(12): 1133-1156.

McEvily, B., Jaffee, J., \& Tortoriello, M. 2012. Not all bridging ties are equal: Network imprinting and firm growth in the Nashville legal industry, 1933-1978. Organization Science, 23(2): 547-563.

McFadyen, M. A., Semadeni, M., \& Cannella Jr, A. A. 2009. Value of strong ties to disconnected others: Examining knowledge creation in biomedicine. Organization science, 20(3): 552-564. 
Mosey, S., \& Wright, M. 2007. From human capital to social capital: A longitudinal study of technology-based academic entrepreneurs. Entrepreneurship Theory and Practice, 31(6): 909-935.

Nerkar, A., \& Paruchuri, S. 2005. Evolution of R\&D capabilities: The role of knowledge networks within a firm. Management Science, 51(5): 771-785.

O'Connor, K. M., \& Gladstone, E. 2018. Beauty and social capital: Being attractive shapes social networks. Social Networks, 52: 42-47.

O'Mahony, S., \& Bechky, B. A. 2006. Stretchwork: Managing the career progression paradox in external labor markets. Academy of Management Journal, 49(5): 918-941.

Obstfeld, D. 2005. Social networks, the Tertius lungens and orientation involvement in innovation. Administrative Science Quarterly, 50(1): 100-130.

Obstfeld, D., Borgatti, S. P., \& Davis, J. 2014. Brokerage as a process: Decoupling third party action from social network structure. In D. J. Brass, G. Labianca, A. Mehra, D. S. Halgin and S. P. Borgatti (Eds.), Research in the Sociology of Organizations: 135-159. Bingley, UK: Emerald Books.

Obukhova, E., \& Lan, G. 2013. Do job seekers benefit from contacts? A Direct Test with Contemporaneous Searches. Management Science, 59(10): 2204-2216.

Oh, H., \& Kilduff, M. 2008. The ripple effect of personality on social structure: Self-monitoring origins of network brokerage. Journal of Applied Psychology, 93(5): 1155-1164.

Oh, H., Labianca, G., \& Chung, M.-H. 2006. A multilevel model of group social capital. Academy of Management Review, 31(3): 569-582.

Opsahl, T., Agneessens, F., \& Skvoretz, J. 2010. Node centrality in weighted networks: Generalizing degree and shortest paths. Social Networks, 32(3): 245-251.

Owen-Smith, J., \& Powell, W. W. 2004. Knowledge networks as channels and conduits: The effects of spillovers in the Boston biotechnology community. Organization Science, 15(1): 5-21.

Ozdemir, S. Z., Moran, P., Zhong, X., \& Bliemel, M. J. 2016. Reaching and acquiring valuable resources: The entrepreneur's use of brokerage, cohesion, and embeddedness. Entrepreneurship Theory and Practice, 40(1): 49-79.

Podolny, J. M. 2001. Networks as the pipes and prisms of the market. American Journal of Sociology, 107(1): 33-60.

Pollock, T. G., Porac, J. F., \& Wade, J. B. 2004. Constructing deal networks: brokers as network "architects" in the U.S. IPO market and other examples. Academy of Management Review, 29(1): 50-72.

Quintane, E., \& Carnabuci, G. 2016. How do brokers broker? Tertius gaudens, tertius iungens, and the temporality of structural holes. Organization Science, 27(6): 1343-1360.

Reiche, B. S., Harzing, A. W., \& Kraimer, M. L. 2009. The role of international assignees' social capital in creating inter-unit intellectual capital: A cross-level model. Journal of International Business Studies, 40(3): 509-526.

Reinholt, M., Pedersen, T., \& Foss, N. J. 2011. Why a central network position isn't enough: The role of motivation and ability for knowledge sharing in employee networks. Academy of Management Journal, 54(6): 1277-1297.

Rhee, L., \& Leonardi, P. M. 2018. Which pathway to good ideas? An attention-based view of innovation in social networks. Strategic Management Journal, 39(4): 1188-1215.

Rider, C. I. 2009. Constraints on the control benefits of brokerage: A study of placement agents in U.S. venture capital fundraising. Administrative Science Quarterly, 54(4): 575-601.

Rosenkopf, L., \& Almeida, P. 2003. Overcoming local search through alliances and mobility. Management Science, 49(6): 751-766. 
Rost, K. 2011. The strength of strong ties in the creation of innovation. Research Policy, 40(4): 588-604.

Rubineau, B., \& Fernandez, R. M. 2013. Missing links: Referrer behavior and job segregation. Management Science, 59(11): 2470-2489.

Ryall, M. D., \& Sorenson, O. 2007. Brokers and competitive advantage. Management Science, 53(4): 566-583.

Sapsed, J., Grantham, A., \& DeFillippi, R. 2007. A bridge over troubled waters: Bridging organisations and entrepreneurial opportunities in emerging sectors. Research Policy, 36(9): 1314-1334.

Sasovova, Z., Mehra, A., Borgatti, S. P., \& Schippers, M. C. 2010. Network churn: The effects of self-monitoring personality on brokerage dynamics. Administrative Science Quarterly, 55(4): 639-668.

Seabright, M. A., Levinthal, D. A., \& Fichman, M. 1992. Role of individual attachments in the dissolution of interorganizational relationships. Academy of Management Journal, 35(1): 122-160.

Sgourev, S. V. 2015. Brokerage as catalysis: How Diaghilev's ballets russes escalated modernism. Organization Studies, 36(3): 343-361.

Shah, N. P., Levin, D. Z., \& Cross, R. 2018. Secondhand social capital: Boundary spanning, secondhand closure, and individual performance. Social Networks, 52: 18-27.

Shi, W., Markoczy, L., \& Dess, G. G. 2009. The role of middle management in the strategy process: Group affiliation, structural holes, and tertius iungens. Journal of Management, 35(6): 1453-1480.

Shi, W. L., Sun, S. L., \& Peng, M. W. 2012. Sub-national institutional contingencies, network positions, and IJV partner selection. Journal of Management Studies, 49(7): 1221-1245.

Shi, W. L., Sun, S. L., Pinkham, B. C., \& Peng, M. W. 2014. Domestic alliance network to attract foreign partners: Evidence from international joint ventures in China. Journal of International Business Studies, 45(3): 338-362.

Shipilov, A. V. 2006. Network strategies and performance of Canadian investment banks. Academy of Management Journal, 49(3): 590-604.

Shipilov, A. V. 2009. Firm scope experience, historic multimarket contact with partners, centrality, and the relationship between structural holes and performance. Organization Science, 20(1): 85-106.

Shipilov, A. V., \& Li, S. X. 2008. Can you have your cake and eat it too? Structural holes' influence on status accumulation and market performance in collaborative networks. Administrative Science Quarterly, 53(1): 73-108.

Shipilov, A. V., \& Li, S. X. 2012. The missing link: The effect of customers on the formation of relationships among producers in the multiplex triads. Organization Science, 23(2): 472491.

Shipilov, A. V., Li, S. X., \& Greve, H. R. 2011. The prince and the pauper: Search and brokerage in the initiation of status-heterophilous ties. Organization Science, 22(6): 1418-1434.

Smith, S. S. 2005. "Don't put my name on it": Social capital activation and job-finding assistance among the black urban poor. American Journal of Sociology, 111(1): 1-57.

Soda, G., Tortoriello, M., \& Iorio, A. 2018. Harvesting value from brokerage: Individual strategic orientation, structural holes, and performance. Academy of Management Journal, 61(3): 896-918.

Somaya, D., Williamson, I. O., \& Lorinkova, N. 2008. Gone but not lost: The different performance impacts of employee mobility between cooperators versus competitors. Academy of Management Journal, 51(5): 936-953. 
Spiro, E. S., Acton, R. M., \& Butts, C. T. 2013. Extended structures of mediation: Re-examining brokerage in dynamic networks. Social Networks, 35(1): 130-143.

Stam, W. 2010. Industry event participation and network brokerage among entrepreneurial ventures. Journal of Management Studies, 47(4): 625-653.

Stam, W., \& Elfring, T. 2008. Entrepreneurial orientation and new venture performance: The moderating role of intra- and extraindustry social capital. Academy of Management Journal, 51(1): 97-111.

Stevenson, W. B., \& Greenberg, D. 2000. Agency and social networks: Strategies of action in a social structure of position, opposition, and opportunity. Administrative Science Quarterly, 45(4): 651-678.

Stovel, K., \& Shaw, L. 2012. Brokerage. Annual Review of Sociology, 38(1): 139-158.

Stuart, T. E., Ozdemir, S. Z., \& Ding, W. W. 2007. Vertical alliance networks: The case of university-biotechnology-pharmaceutical alliance chains. Research Policy, 36(4): 477498.

Sullivan, B. N., Tang, Y., \& Marquis, C. 2014. Persistently learning: How small-world network imprints affect subsequent firm learning. Strategic Organization, 12(3): 180-199.

Sytch, M., \& Tatarynowicz, A. 2014. Friends and foes: The dynamics of dual social structures. Academy of Management Journal, 57(2): 585-613.

Tasselli, S. 2015. Social networks and inter-professional knowledge transfer: The case of healthcare professionals. Organization Studies, 36(7): 841-872.

Tasselli, S., \& Kilduff, M. 2017. When brokerage between friendship cliques endangers trust: A personality-network fit perspective. Academy of Management Journal, 61(3): 802-825.

Ter Wal, A. L. J., Alexy, O., Block, J., \& Sandner, P. G. 2016. The best of both worlds: The benefits of open-specialized and closed-diverse syndication networks for new ventures' success. Administrative Science Quarterly, 61(3): 393-432.

Tiwana, A. 2008. Do bridging ties complement strong ties? An empirical examination of alliance ambidexterity. Strategic Management Journal, 29(3): 251-272.

Tortoriello, M. 2015. The social underpinnings of absorptive capacity: The moderating effects of structural holes on innovation generation based on external knowledge. Strategic Management Journal, 36(4): 586-597.

Tortoriello, M., \& Krackhardt, D. 2010. Activating cross-boundary knowledge: The role of Simmelian ties in the generation of innovations. Academy of Management Journal, 53(1): 167-181.

Tortoriello, M., Reagans, R., \& McEvily, B. 2012. Bridging the knowledge gap: The influence of strong ties, network cohesion, and network range on the transfer of knowledge between organizational units. Organization Science, 23(4): 1024-1039.

Uzzi, B. 1999. Embeddedness in the making of financial capital: How social relations and networks benefit firms seeking financing. American Sociological Review, 64(4): 481-505.

Uzzi, B., \& Spiro, J. 2005. Collaboration and creativity: The small world problem. American Journal of Sociology, 111(2): 447-504.

van Wijk, J., Stam, W., Elfring, T., Zietsma, C., \& den Hond, F. 2013. Activists and incumbents structuring change: the interplay of agency, culture, and networks in field evolution. Academy of Management Journal, 56(2): 358-386.

Vanhaverbeke, W., Gilsing, V., Beerkens, B., \& Duysters, G. 2009. The role of alliance network redundancy in the creation of core and non-core technologies. Journal of Management Studies, 46(2): 215-244. 
Vasudeva, G., Zaheer, A., \& Hernandez, E. 2013. The embeddedness of networks: Institutions, structural holes, and innovativeness in the fuel cell industry. Organization Science, 24(3): 645-663.

Vedres, B., \& Stark, D. 2010. Structural folds: Generative disruption in overlapping groups. American Journal of Sociology, 115(4): 1150-1190.

Verona, G., Prandelli, E., \& Sawhney, M. 2006. Innovation and virtual environments: Towards virtual knowledge brokers. Organization Studies, 27(6): 765-788.

Vissa, B. 2012. Agency in action: Entrepreneurs' networking style and initiation of economic exchange. Organization Science, 23(2): 492-510.

Vissa, B., \& Chacar, A. S. 2009. Leveraging ties: The contingent value of entrepreneurial teams' external advice networks on Indian software venture performance. Strategic Management Journal, 30(11): 1179-1191.

Walker, G., Kogut, B., \& Shan, W. J. 1997. Social capital, structural holes and the formation of an industry network. Organization Science, 8(2): 109-125.

Wanberg, C. R., Kanfer, R., \& Banas, J. T. 2000. Predictors and outcomes of networking intensity among unemployed job seekers. Journal of Applied Psychology, 85(4): 491-503.

Wang, C. L., Rodan, S., Fruin, M., \& Xu, X. Y. 2014. Knowledge networks, collaboration networks, and exploratory innovation. Academy of Management Journal, 57(2): 484-514.

Wang, D. 2015. Activating cross-border brokerage: Interorganizational knowledge transfer through skilled return migration. Administrative Science Quarterly, 60(1): 133-176.

Williams, T. A., \& Shepherd, D. A. 2018. To the rescue!? Brokering a rapid, scaled and customized compassionate response to suffering after disaster. Journal of Management Studies, 55(6): 910-942.

Wong, S. S., \& Boh, W. F. 2010. Leveraging the ties of others to build a reputation for trustworthiness among peers. Academy of Management Journal, 53(1): 129-148.

Xia, J., Wang, Y. G., Lin, Y., Yang, H. B., \& Li, S. L. 2018. Alliance formation in the midst of market and network: Insights from resource dependence and network perspectives. Journal of Management, 44(5): 1899-1925.

Xiao, Z. X., \& Tsui, A. S. 2007. When brokers may not work: The cultural contingency of social capital in Chinese high-tech firms. Administrative Science Quarterly, 52(1): 1-31.

Yang, H. B., Lin, Z., \& Peng, M. W. 2011. Behind acquisitions of alliance partners: Exploratory learning and network embeddedness. Academy of Management Journal, 54(5): 10691080.

Yin, X. L., Wu, J. F., \& Tsai, W. P. 2012. When unconnected others connect: Does degree of brokerage persist after the formation of a multipartner alliance? Organization Science, 23(6): 1682-1699.

Youtie, J., \& Shapira, P. 2008. Building an innovation hub: A case study of the transformation of university roles in regional technological and economic development. Research Policy, 37(8): 1188-1204.

Zaheer, A., \& Bell, G. G. 2005. Benefiting from network position: Firm capabilities, structural holes, and performance. Strategic Management Journal, 26(9): 809-825.

Zaheer, A., \& Soda, G. 2009. Network evolution: The origins of structural holes. Administrative Science Quarterly, 54(1): 1-31.

Zhelyazkov, P. I. 2018. Interactions and interests: Collaboration outcomes, competitive concerns, and the limits to triadic closure. Administrative Science Quarterly, 63(1): 210-247.

Zheng, W. 2010. A social capital perspective of innovation from individuals to nations: Where is empirical literature directing us? International Journal of Management Reviews, 12(2): 151-183. 